\title{
DA RESPONSABILIDADE CIVIL EX LEGE POR CONFLITO DE DIREITOS
}

\author{
DISSERTAÇÃO DE MESTRADO \\ PROFESSORA ORIENTADORA \\ GISELDA MARIA FERNANDES NOVAES HIRONAKA
}

FACULDADE DE DIREITO

UNIVERSIDADE DE SÃO PAULO

SÃO PAULO 


\section{RUBENS LEONARDO MARIN}

\section{DA RESPONSABILIDADE CIVIL EX LEGE POR CONFLITO DE DIREITOS}

Dissertação apresentada à Banca Examinadora da Faculdade de Direito da Universidade de São Paulo, como exigência parcial para a obtenção do título de Mestre em Direito Civil, sob a orientação da Professora Associada do Departamento de Direito Civil da Faculdade de Direito da Universidade de São Paulo Giselda Maria Fernandes Novaes Hironaka.

UNIVERSIDADE DE SÃO PAULO

SÃO PAULO

2007 
Banca Examinadora 
À Professora Giselda Hironaka, pelo exemplo de ser humano, de educadora e de profissional, os quais nunca ousarei esquecer e que me fazem crer na possibilidade de manter o afeto também no Direito.

Aos meus familiares, pela compreensão e suporte durante toda a jornada.

Aos meus amigos, sempre leais, e em especial àqueles que me auxiliaram e me acompanharam nesta jornada.

À Luciana, pelo apoio, carinho e cumplicidade sempre presentes. 
“... se manter o que é, somente porque é, constitui regra de prudência, muitas vezes não o será de sabedoria...”. (p. 10)

“O mais fácil raramente é o melhor; e não teríamos qualquer esboço de civilização, se as invocações não acabassem por vencer as resistências...”. (p. 11)

(PONTES DE MIRANDA, Francisco Cavalcanti. Fonte e evolução do direito civil brasileiro. Rio de Janeiro: 


\section{RESUMO}

O presente estudo visa investigar a categoria jurídica autônoma que, ao lado da culpa e do risco, oferece fundamento à responsabilidade civil, a qual denominou-se responsabilidade civil ex lege por conflito de direitos.

Essa categoria é apresentada como a justa solução do legislador a um conflito entre direitos que, uma vez impossível sua conciliação no mesmo tempo e espaço, determina-se que um dos direitos prevaleça, desde que seja garantida a obrigação indenizatória dos danos sofridos ao que suporta o seu exercício.

A tarefa apenas é possível, pois o instituto da responsabilidade civil, após séculos, abandonou a exigência da culpa como seu único fundamento, e agora centrado no seu elemento dano e na resposta do ordenamento jurídico à sua ocorrência, permite ampliações ao seu conceito.

Apresentaram-se os elementos necessários para configuração da categoria jurídica por meio dos índices de caracterização de seu tipo. E, por fim, ofereceram-se hipóteses existentes no ordenamento jurídico, especialmente no Código Civil, de obrigações indenizatórias, cujo fundamento diverge da culpa e do risco e que, portanto, permitem o estudo como hipóteses de responsabilidade ex lege por conflito de direitos. 


\section{ABSTRACT}

This study aims at investigating an independent legal category that, along with the guilt and the risk, offers basis to the civil liability, named as civil liability ex lege due to conflict of rights.

This category is presented as the fair solution provided by the legislator to a collision of rights whose concurrent conciliation is impossible, and as result, it is determined that one of the rights prevails, provided that compensation of the damages to whom supports it be guaranteed.

The task is only possible, for the institute of the civil liability, after centuries, has abandoned the guilt requirement as its only basis for civil liabilities, and now centered in its element damage and the reply of the legal system to its occurrence, allows for the concept's enlargement in its objective to repair it.

Thus, there has been presented the necessary elements for configuration of the legal category as identification of its type. Finally, there has been offered some hypotheses of existing indemnified obligations in the legal system, and specially in the Civil Code, whose basis differs from guilt and risk and, therefore, allows the study as hypotheses of civil liability ex lege due to conflict of rights. 


\section{SUMÁRIO}



1. Justificativa do tema do estudo............................................................................ 14

2. Metodologia utilizada e técnicas de pesquisa adotadas ............................................. 16

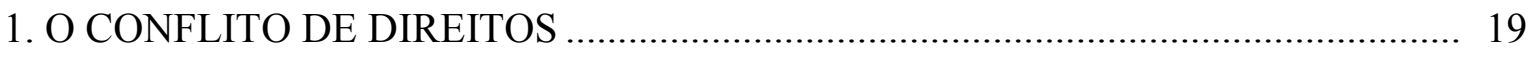



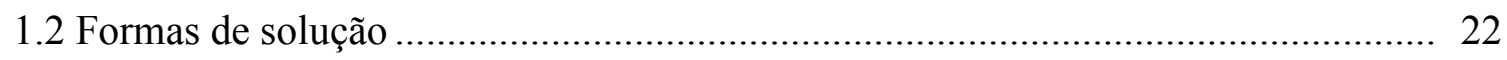

2. A RESPONSABILIDADE - POSIÇÃO SISTEMÁTICA ……………………………... 27

2.1 Noção da responsabilidade civil por conflito de direitos ........................................... 27

2.1.1 Análise crítica dos conceitos e posições de alguns doutrinadores .................. 29

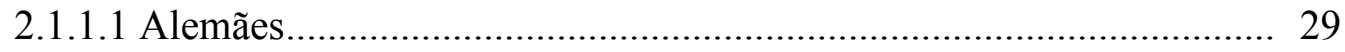

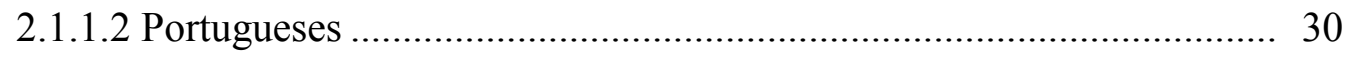

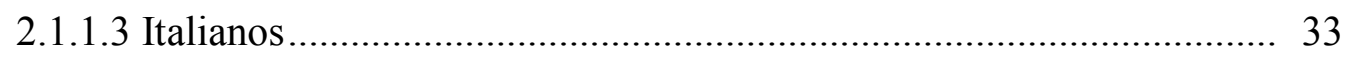

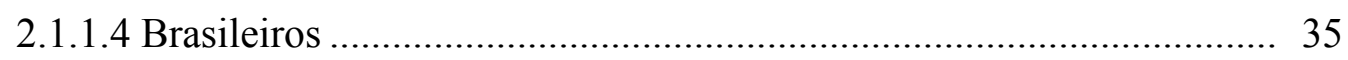

2.2 A questão terminológica ............................................................................... 39

2.3 Natureza jurídica e posição no sistema da responsabilidade civil............................. 41

2.3.1 Novas concepções sobre responsabilidade civil............................................ 42

2.3.2 $\mathrm{O}$ conflito de direitos como fundamento da responsabilidade ........................ 47

2.3.3 Natureza extracontratual.............................................................................. 55

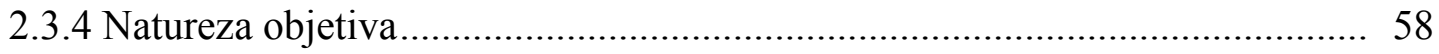

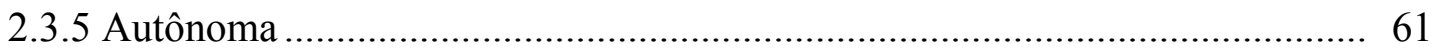

3. A RESPONSABILIDADE - ÍNDICES CARACTERIZADORES E APLICAÇÃO ... 66

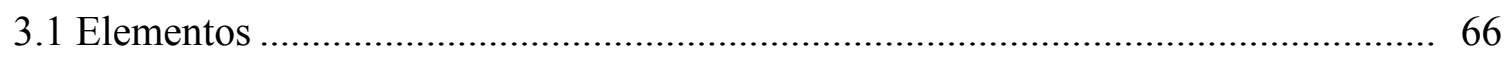

3.1.1 Elementos comuns a todas as espécies de responsabilidade ........................... 68

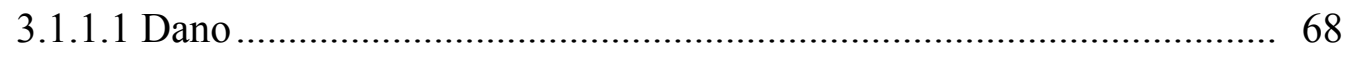

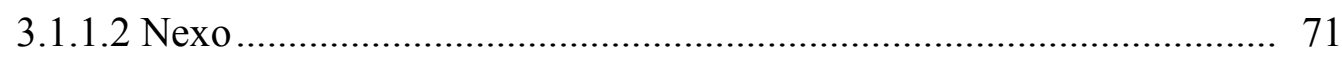

3.1.2 Elementos específicos (differentia especifica) .............................................. 73 
3.1.2.1 Exercício regular de um direito..................................................... 74

3.1.2.2 Conflito de direitos ....................................................................... 76

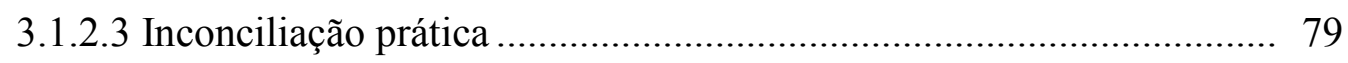

3.1.2.4 Solução legislativa ................................................................. 80

3.1.2.5 Sobreposição do direito mais importante.......................................... 82

3.1.2.6 Dano permitido e desequilíbrio injusto.......................................... 84

3.1.2.7 Reparação devida ................................................................... 86

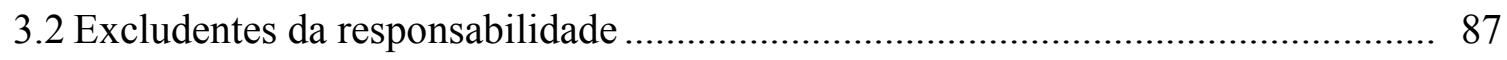

3.2.1 Inoponibilidade das excludentes de ilicitude........................................... 88

3.2.2 As excludentes de nexo ..................................................................... 91

3.2.2.1 Caso fortuito e força maior ........................................................... 92

3.2.2.2 Ato da vítima........................................................................... 95

3.2.2.3 Ato de terceiro........................................................................ 96

\section{HIPÓTESES DE APLICAÇÃO NO CÓDIGO CIVIL E NA LEGISLAÇÃO}

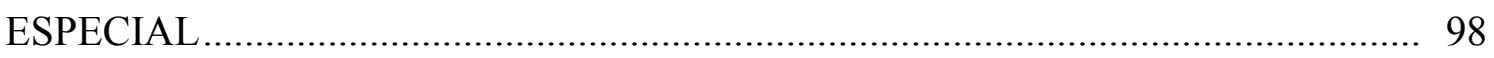

4.1 Obrigação de compensar danos causados em estado de necessidade...................... 99

4.1.1 Estado de necessidade como espécie (stricto sensu) ...................................... 99

4.1.2 Legítima defesa real e putativa................................................................ 103

4.2 Obrigação de compensar danos resultantes de limitações ao domínio baseados no interesse social de coexistência pacífica de direitos individuais .......................... 106

4.2.1 Passagem forçada ............................................................................... 108

4.2.2 Uso do prédio confinante ................................................................... 111

4.2.3 Servidão de aqueduto ...................................................................... 113

4.2.4 Águas artificiais colhidas pelo prédio inferior .......................................... 114

4.2.5 Elevação artificial das águas .................................................................. 116

4.3 Obrigação de compensar danos resultantes de restrições ao domínio em virtude

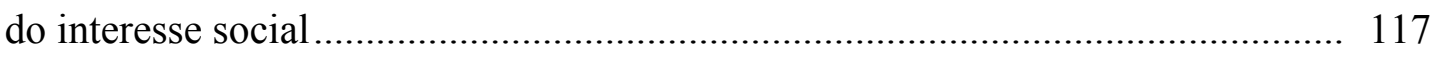

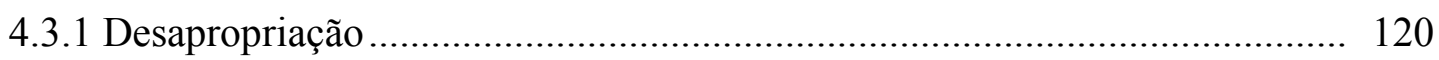

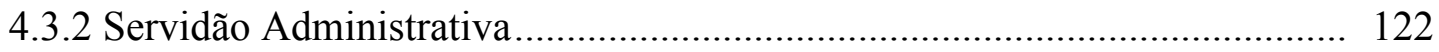

4.4 Obrigação de compensar danos resultantes do exercício da tutela jurídica ............... 123

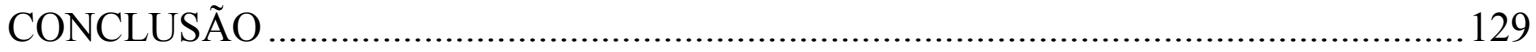

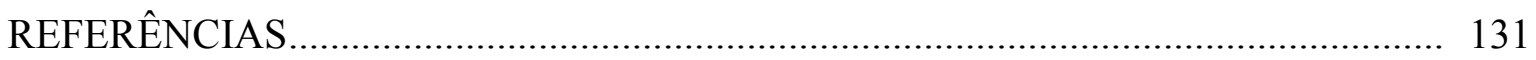




\section{INTRODUÇÃO}

$\mathrm{Na}$ atualidade, a proteção dos direitos fundamentais é a tônica do Estado de Direito. Cumprindo o desígnio de "dar a cada um o que é seu", o Estado reconhece os mais variados direitos aos cidadãos, seja no âmbito constitucional ou mediante legislação ordinária.

Contudo, na prática, nem sempre é possível estabelecer a convivência harmônica e simultânea do conjunto de todos esses direitos ${ }^{1}$. Há excesso de direitos e escassez de bens, ou seja, cada direito concedido a uma parte é, muitas vezes, uma perda do direito de outra ${ }^{2}$. Dessa forma, quando de seu exercício, existe um conflito de direitos.

Para os casos em que ocorre essa tensão de direitos criada pela existência de dois comportamentos lícitos, contrários e inconciliáveis entre si, o ordenamento jurídico prevê duas formas de solução: a) ex lege ou legislativa, na qual o legislador, prevendo a situação conflituosa, estabelece a solução possível; e b) ex iudicio ou judicial, na qual o juiz, diante do caso concreto, com o apoio da doutrina e da jurisprudência, determina, a posteriori, a solução aplicável. Seja pela forma ex lege, seja pela ex iudicio, os pontos a serem solucionados são basicamente dois: qual dos direitos deve prevalecer, e se aos prejudicados é devida a compensação dos danos eventualmente sofridos.

Este estudo visa esboçar traços sobre a primeira das hipóteses de solução quando de uma colisão entre direitos: aquela determinada, a priori, pelo legislador, na qual se determinou a obrigação de compensar danos resultantes deste conflito de direitos legítimos.

1 ZAVASCKI, Teori Albino. Antecipação de tutela e colisão de direitos fundamentais. Revista do Tribunal Regional Federal $1^{a}$ Região, v. 7, n. 3, jul./set. 1995, p. 15.

2 LORENZETTI, Ricardo Luis. Fundamentos do direito privado. São Paulo: RT, 1998. p. 433. 
Trata-se, como se pode observar, de um caso de indenização decorrente de um exercício regular de um direito, ou seja, de uma atividade lícita, na qual surge, para o autor, a obrigação de compensar os danos sofridos por aquele que suportou esse exercício, isto é, “a própria ordem jurídica autoriza o fato danoso, conquanto estabeleça a simultaneidade do ressarcimento"3.

Entende-se esse tipo de reparação, à semelhança de Karl Larenz ${ }^{4}$, como um terceiro gênero no fundamento do dever de indenizar. O primeiro seria o ato ilícito; o segundo, os riscos objetivos; e, por fim, as transgressões lícitas e permitidas. Na concepção do citado jurista alemão, essas últimas, entendidas como hipóteses de responsabilidade civil por conflito de direitos, seriam atos permitidos pelo ordenamento jurídico, mas que, por força dos ditames da justiça comutativa, ou mesmo da justiça distributiva, prescrevem uma indenização que visa compensar o prejuízo experimentado pelo prejudicado.

A legislação vigente, mesmo que timidamente, já vislumbra a existência dos três fundamentos do dever de indenizar na forma exposta. O artigo 927 do Código Civil vigente claramente dispõe, em seu caput, sobre a responsabilidade civil decorrente de conduta culposa, ou seja, hipóteses de responsabilidade civil subjetiva ${ }^{5}$.

O parágrafo único do mesmo artigo, por seu turno, prevê a existência de obrigação de reparar danos, independentemente de culpa, nas hipóteses de existência de riscos objetivos e "nos casos especificados em lei”. Nesse ponto é que estão as hipóteses da categoria em estudo ${ }^{6}$.

Alguns exemplos dessa categoria jurídica são: a) a responsabilidade decorrente de ato praticado em estado de necessidade (artigo 929 do Código Civil $^{7}$ ); b) a indenização cabal devida aos donos dos prédios por onde se estabelece a passagem forçada (artigo

BAPTISTA, Silvio Neves. Ensaio sobre a teoria do fato danoso. Revista de Direito Civil, São Paulo, RT, n. 67, 1994. p. 57.

4 Derecho de obligaciones. Madrid: Editorial Revista de Derecho Privado, 1959. t. II, § 72, p. 690.

5 Art. 927: "Aquele que, por ato ilícito (arts. 186 e 187), causar dano a outrem, fica obrigado a repará-lo".

6 Art 927, parágrafo único: "Haverá obrigação de reparar o dano, independentemente de culpa, nos casos especificados em lei, ou quando a atividade normalmente desenvolvida pelo autor do dano implicar, por sua natureza, risco para os direitos de outrem".

7 Art. 929: "Se a pessoa lesada, ou o dono da coisa, no caso do inc. II do art. 188, não forem culpados do perigo, assistir-lhes-á direito à indenização do prejuízo que sofreram". 
1.285 do Código $\mathrm{Civil}^{8}$ ), entre outras decorrentes do direito de vizinhança (por exemplo, artigos $1.286^{9}, 1.293^{10}$ e $1.313^{11}$ do Código Civil); e c) as limitações de domínio baseadas no interesse público, como as desapropriações (Constituição Federal de 1988, artigo $5^{\circ}$, inciso XXIV).

Esse tipo de categoria jurídica apenas é passível de ser enquadrado no sistema da responsabilidade civil em virtude da substituição da conduta ilícita pelo dano como centro metodológico da responsabilidade civil ${ }^{12}$. O dano retoma, desse modo, o seu lugar como fundamento primeiro da responsabilidade civil após séculos de prevalência da culpa ${ }^{13}$.

Nessa visão, não é mais possível se conceber a responsabilidade civil como obrigação que visa à punição ao culpado, mas, sim, como uma categoria neutra, que busca o restabelecimento da situação injustamente alterada, conciliando deveres e direitos tanto daquele que dana como do que sofre o dano ${ }^{14}$.

Assim, na situação em tela, o exercício de um direito, mesmo que legítimo e lícito, ofende direito alheio e, nessa tensão de duas forças lícitas, entende o legislador que um direito deve prevalecer, porém à outra parte é devida uma reparação pela ofensa a seu direito. Em tais hipóteses, configurar-se-ia, portanto, a responsabilidade civil ex lege por conflito de direitos, tema do presente estudo.

8 Art. 1.285: “O dono do prédio que não tiver acesso à via pública, nascente ou porto, pode, mediante pagamento de indenização cabal, constranger o vizinho a lhe dar passagem, cujo rumo será judicialmente fixado se necessário".

9 Art. 1.286: "Mediante recebimento de indenização que atenda, também, à desvalorização da área remanescente, o proprietário é obrigado à tolerar a passagem, através de seu imóvel, de cabos, tubulações e outros condutos subterrâneos de serviços de utilidade pública, em proveito de proprietários vizinhos, quando de outro modo for impossível ou excessivamente onerosa".

10 Art. 1.293: "É permitido a quem quer que seja, mediante prévia indenização aos proprietários prejudicados, construir canais através de prédios alheios para receber as águas a que tenha direito, indispensáveis às primeiras necessidades da vida, e, desde que não cause prejuízo considerável à agricultura e à indústria, bem como para o escoamento de águas supérfluas ou acumuladas, ou a drenagem de terrenos".

11 Art. 1.313: "O proprietário ou ocupante do imóvel é obrigado a tolerar que o vizinho entre no prédio, mediante prévio aviso, para: I - dele temporariamente usar, quando indispensável à reparação, construção, reconstrução ou limpeza de sua casa ou do muro divisório; (...) $\S 3^{\circ}$ Se do exercício do direito assegurado neste artigo provier dano, terá o prejudicado direito a ressarcimento".

12 HIRONAKA, Giselda Maria Fernandes Novaes. Responsabilidade pressuposta. Belo Horizonte: Del Rey, 2005. p. 2 e ss.

13 PEREIRA, Caio Mário da Silva. Responsabilidade civil. 9. ed. Rio de Janeiro: Forense, 2001. $\S 5^{\circ}$, p. 4 e ss.

14 LORENZETTI, Ricardo Luis. El sistema de la responsabilidad civil ¿Una deuda de responsabilidad, un crédito de indemnización o una relación jurídica? Ajuris, Porto Alegre, n. 63, 1995, p. 166 e ss. 


\section{JUSTIFICATIVA DO TEMA DO ESTUDO}

O interesse no tema responsabilidade civil ex lege por conflito de direitos decorre da existência de hipóteses de responsabilidade civil, cujo fundamento não está na conduta ilícita ou na existência de riscos objetivos.

Obras dedicadas ao estudo da responsabilidade civil em sua categoria subjetiva indicam séculos de desenvolvimento de tal categoria. No último século, por seu turno, verificou-se dedicação aos estudos relacionados às hipóteses de responsabilidade civil decorrentes dos riscos objetivos.

Todavia, no desenvolvimento da pesquisa bibliográfica, verificamos que a doutrina aborda timidamente o fundamento da reparação indenizatória nos casos de responsabilidade civil decorrente do conflito de direitos. Não raro, há uma completa omissão quanto ao assunto.

Supomos que esse silêncio decorra de dois motivos principais. Primeiro, a pouca dificuldade de aplicação dos dispositivos legais associados à categoria. A reparação indenizatória oriunda das hipóteses relacionadas à categoria em estudo decorre da aplicação da lei criada especificamente para cada caso, pela mera subsunção da norma aos fatos. Assim, ficam reduzidas as interpretações divergentes no momento da aplicação da norma, e o interesse prático de tal estudo diminui.

Reafirma-se, o estudo da categoria da responsabilidade civil por conflito de direitos, nesse momento, apenas visa à organização teórica das hipóteses de responsabilidade civil.

A segunda razão para o silêncio doutrinário residiria no fato de que as hipóteses estão pulverizadas por toda a legislação e relacionadas aos mais diversos pressupostos fáticos. Então, quaisquer conclusões envolvendo tal diversidade de hipóteses pouco poderiam avançar em conclusões no plano teórico. 
Esses argumentos - que, ressalte-se, são ilações sobre prováveis motivos da omissão da doutrina sobre a categoria objeto deste estudo ${ }^{15}$ - não prevalecem. Em relação ao primeiro argumento, pode-se afirmar que, mesmo em se tratando de hipóteses devidamente especificadas em lei, cada uma, observada em suas características próprias, possui questões extremamente importantes a serem debatidas no âmbito doutrinário. Cita-se como exemplo a questão da escolha do legislador sobre o direito a prevalecer. É mesmo a mais acertada no caso concreto? Cabem excludentes à sua opção, as quais devem ser interpretadas pelo aplicador do direito? O conflito já está devidamente solucionado pelo legislador ou deve ser levantada uma antinomia valorativa, decidindo o julgador por eqüidade? As questões são as mais variadas na aplicação desse tipo de responsabilidade e não se pode relegar o seu estudo a um segundo plano.

Já o segundo argumento deve ser visto cum grano salis. O fato de as hipóteses de responsabilidade ex lege, decorrente de conflito entre direitos, estarem pulverizadas por toda a legislação não implica desagregação doutrinária. A diversidade dos fatos não impossibilita a formação de uma teoria geral. Contudo, deve-se tomar o instituto em um plano um pouco mais elevado e abstrato, não o tratando com os fatos descritos especificamente com a lei para sua ocorrência (que devem ser abordados em uma parte especial), mas com suas características comuns, seus elementos gerais. Dessa forma, viabiliza-se o estudo desse tipo especial de responsabilidade como categoria que está no mesmo plano sistemático dos atos ilícitos e dos riscos objetivos.

Essa dispersão das hipóteses por todos os ramos do direito apenas demonstra, também, a importância de um instituto que não pode ser tratado como mero casuísmo ou exceção a uma regra, mas que merece um cuidado próprio e especial.

Assim, deve ser renovada a necessidade do estudo de tal categoria com o objetivo de contribuir para o desenvolvimento da responsabilidade civil ex lege por conflito de direitos como categoria autônoma e, conseqüentemente, oferecer alguma contribuição ao aperfeiçoamento da responsabilidade civil no âmbito de sua teoria geral.

15 Apenas VARELA, João Matos Antunes (Das obrigações em geral. Coimbra: Almedina, 1970. p. 492) manifesta-se no sentido da desnecessidade do estudo genérico da questão no direito português. Para tanto, cita o casuísmo das hipóteses e a retirada, do projeto que originou o Código Civil português de 1966, do princípio genérico dessa categoria. 
Para o desenvolvimento deste trabalho, buscou-se, essencialmente, o estudo do tratamento doutrinário oferecido às hipóteses de responsabilidade civil estranhas aos fundamentos das condutas ilícitas e das condutas que oferecem riscos objetivos.

Trabalhou-se, portanto, com as hipóteses cujo enquadramento nos dois primeiros fundamentos da responsabilidade civil era inadequado, e que pouco ou nada contribuíam à justificativa racional da obrigação indenizatória.

Tratando-se de categoria residual, formada inicialmente por critério excludente, grandes seriam as possibilidade de dispersão da pesquisa em rol extenso de hipóteses, enfraquecendo o presente estudo. Para evitar tal fato, manteve-se a guia da pesquisa na legislação, pois daqui decorre a força do instituto. Por isso, fez-se a opção pelo estudo da responsabilidade civil ex lege, relegando-se as hipóteses ex judicio a estudo posterior.

Observado o tratamento doutrinário oferecido, buscou-se viabilizar o enquadramento de tal hipótese no sistema da teoria geral da responsabilidade civil.

Por se tratar, em última análise, de responsabilidade civil decorrente de uma conduta em exercício regular de um direito, apenas pela afirmação dos princípios contemporâneos que norteiam o instituto da responsabilidade civil, tais como: a primazia do interesse da vítima, a máxima reparação do dano e a solidariedade social $^{16}$, tal empreitada tornou-se possível.

Em momento posterior, visou-se oferecer as similitudes, que aproximam a categoria da responsabilidade civil ex lege por conflito de direitos aos demais elementos do sistema da responsabilidade, especialmente aos fundamentos da conduta ilícita e dos riscos objetivos, porém oferecendo ainda a sua diferença específica quanto a estes institutos.

Assim, a inserção desse tipo de obrigação no sistema da responsabilidade civil deu-se tomando tal instituto como um fundamento autônomo gerador de obrigação de

16 LOBO, Paulo Luiz Netto. Teoria geral das obrigações. São Paulo: Saraiva, 2005. p. 14. 
ressarcir o dano, e não como mero apêndice decorrente de exceções à regra geral da responsabilidade civil ${ }^{17}$. Pelo contrário, defendeu-se sua posição de igualdade e autonomia diante dos outros fundamentos da responsabilidade civil, buscando-se, nessa nova visão, seus princípios, elementos, dinâmica e hipóteses práticas de aplicação.

Delinearam-se, em síntese, três categorias gerais que ensejam a obrigação indenizatória: a) a ação proibida que rompe com o ordenamento jurídico, e nesse ato prejudica terceiro (ato ilícito); b) a ação permitida que cria uma situação perigosa (riscocriado) ou dela tira proveito (risco-proveito); e c) a ação permitida que, em exercício regular de direito, causa dano a outro direito, dano que a vítima não é obrigada a suportar.

Após a análise da categoria em estudo em suas relações externas com os demais institutos que integram o sistema da responsabilidade civil, passou-se à análise de seus elementos internos, ou seja, os índices caracterizadores do tipo.

Como a categoria em tela é um fundamento jurídico, atenção especial foi dada ao seu suporte fático, isto é, ao conjunto de fatos que, presentes e interligados em uma mesma situação, originam a relação jurídica indenizatória. Foram oferecidos, assim, os elementos específicos que a caracterizam ${ }^{18}$.

Este estudo aspirou também a abordar o tema responsabilidade civil pelo seu modo mais estável e seguro e, portanto, doutrinariamente mais adequado, isto é, o seu fundamento. Houve o cuidado de não se cometer o erro de, no desenvolvimento do tema, determinar apenas sua casuística e vicissitudes de aplicação, e incorrer, desse modo, em uma petitio principii, dando por certo o que deveria ser questionado. Antes, preferiu-se buscar os fundamentos da reparação, suas origens e justificações.

Buscou-se também, de forma diligente, a aproximação entre teoria e realidade. Mesmo em se tratando de tema doutrinariamente complexo, partiu-se, muitas vezes, apenas da análise do fato em si, independentemente de ponderações para, distanciando-se de qualquer pré-conceito, atingir-se a sistematização que, humildemente, entende-se ser a adequada.

17 No mesmo sentido: CASTILLA, Gustavo Ordoqui. Obligación de compensar daños causados por conductas lícitas. Revista dos Tribunais, n. 726, 1996, p. 12; LARENZ, Karl. Derecho de obligaciones, § 72, p. 690.

18 LARENZ, Karl. Metodologia da ciência do direito. 3. ed. Lisboa: Fundação Calouste Gulbenkian, 1997. p. 655 e ss. 
Para tanto, foi ofertado um rol de hipóteses a serem analisadas com os subsídios dos pressupostos teóricos desenvolvidos na primeira parte do trabalho.

Por fim, ressalte-se que não se pretende, de forma alguma, neste trabalho, esgotar o tema. Pelo contrário, busca-se apenas acenar com alguns primeiros traços de uma grande discussão, tanto das deficiências do ordenamento jurídico na solução de crises no âmbito social como sobre a própria natureza da responsabilidade civil, tudo permeado pelo estudo dessa categoria no escopo da teoria geral da responsabilidade civil. 


\section{O CONFLITO DE DIREITOS}

O conflito é um fato inerente ao próprio Direito. Tanto que, em alguns aspectos, é comum apresentá-lo como "ciência da solução de problemas"19. A noção de direito perpassa, necessariamente, pela composição do conflito de interesses em busca das finalidades da sociedade por justiça e segurança ${ }^{20}$.

Luis Roberto Barroso afirma que a função social do direito é dar valores às situações da vida, criadas pelos interesses mais diversos, e regular-lhes a distribuição entre os homens ${ }^{21}$. Indiscutível é a função ordenadora do Direito sobre a sociedade, coordenando os "interesses que se manifestam na vida social, de modo a organizar a cooperação entre as pessoas e compor os conflitos que se verificarem entre os seus membros" ${ }^{22}$. No entanto, no cumprimento de seu desígnio, o ordenamento jurídico é, em alguns momentos, gerador do próprio mal que visa eliminar o conflito social.

Criado pelo ordenamento jurídico, este tipo muito especial de conflito, na situação em estudo, ocorre quando o ordenamento jurídico admite, numa mesma situação, exercícios regulares de direitos opostos, cuja concordância prática é inconciliável no mesmo tempo e espaço.

LORENZETTI, Ricardo Luis. Fundamentos do direito privado, p. 422.

20 TEPEDINO, Gustavo. Temas de direito civil. 2. ed. Rio de Janeiro: Renovar, 2001. p. 173.

21 BARROSO, Luis Roberto. Interpretação e aplicação da Constituição. 6. ed. São Paulo: Saraiva, 2004. p. 152.

22 GRINOVER, Ada Pelegrini. Teoria geral do processo. 22. ed. São Paulo: Malheiros, 2006. p. 25. 


\subsection{ORIGEM}

A proteção simultânea de interesses opostos tem lugar, por duas razões. A primeira, uma deficiência econômica relacionada ao problema da escassez. Se fosse possível dar aos homens tudo o que desejassem, não haveria conflito, pois todos satisfazer-se-iam. No entanto, “a realidade é que há proliferação de direitos e escassez de bens; direitos que colidem entre si e é necessário adjudicar" ${ }^{\text {,23. }}$.

O ordenamento jurídico, por vezes, apresenta um catálogo de direitos, muitas vezes desconsiderando o fato de que o nosso mundo é marcado pela finitude e pela escassez, o que leva à criação do conflito ${ }^{24}$.

É comum que a concessão de direitos a alguém implique necessariamente na retirada do direito de outro. A opção é, no mais das vezes, excludente. É o caso, por exemplo, da passagem forçada prevista no artigo 1.285 do Código Civil, segundo o qual ao proprietário do prédio encravado é dado o direito à saída para via pública, porém, para satisfazê-lo, é necessário ofender o direito à propriedade de seu vizinho.

Isto ocorre, pois há carência de bens a satisfazer os indivíduos ${ }^{25}$. A escassez relaciona-se ao fato de que há um número restrito de bens produzidos por determinada sociedade, em determinada época. Todavia, a escassez associa-se à limitação dos recursos disponíveis a cada indivíduo, diante dos desejos que são maiores do que tal disponibilidade. O homem, enquanto incivilizado, não tem mais necessidades do que o animal; entretanto, à medida que progride, seus desejos aumentam, diversificam-se, e este passa a ter necessidades de maior quantidade e variedade a serem satisfeitas ${ }^{26}$.

Ao considerar a carência de bens para satisfazer os indivíduos, seja em virtude da mitigação que uma dada renda impõe ao indivíduo, ou em razão da óbvia limitação social imposta pela disponibilidade de fatores de produção (por exemplo, o tamanho da força de trabalho, a existência de terras férteis ou montante de capital e seu grau de desenvolvimento), infere-se que há equivalente carência de bens a cada um atribuídos. Dadas tais limitações, à

LORENZETTI, Ricardo Luis. Fundamentos do direito privado, p. 422.

24 ALEXY, Robert. Direitos fundamentais no estado constitucional democrático. Revista de Direito Administrativo, Rio de Janeiro, n. 217, p. 65, 1999.

25 MORCILLO, Francisco Mochón. Introdução à economia. 2. ed. São Paulo: Makron-Books, 1994. p. 6.

26 MARSHALL, Alfred. Princípios de economia: tratado introdutório. 3. ed. São Paulo: Nova Cultural, 1988. p. 85. 
proporção que surgem pretensões que recaem sobre o mesmo bem, origina-se o conflito, em que cada um exige a subordinação do interesse alheio ao interesse próprio ${ }^{27}$.

Dessa forma, há, inegavelmente, carência de bens atribuídos a cada um pelo ordenamento jurídico para que haja o exercício regular de direitos plenamente protegido de todos, ou ao menos de alguns, num mesmo momento. Esta escassez, quando recai sobre o mesmo bem, gera o conflito, objeto deste estudo.

A segunda razão para proteção de interesses opostos, no ordenamento jurídico, refere-se a critérios legislativos e lógicos.

A descodificação do sistema, a proliferação de leis especiais e dos chamados "microssistemas de direito", a "enxurrada legislativa" que apenas busca o interesse político governante de sua época, descuidando do ordenamento jurídico estabelecido, a pluralidade do tecido social, que motiva a formação de leis das mais diversas a fim de responder as mais variadas questões sociais - entre outros fatores - são potencialmente geradores de conflito entre as normas, e conseqüentemente entre os direitos ali estabelecidos. É o que na visão de Karl Engish ${ }^{28}$ se denomina “direito incorreto", que ofende o princípio da unidade do sistema jurídico e demanda uma solução corretiva.

Chamadas, em sentido amplo, de antinomias, estas formas de conflitos se apresentam nos mais diversos níveis: de contradições de técnicas legislativas, em que no texto legislativo há o uso de um mesmo termo, porém com sentidos diferentes, esta contradição decorre de uma necessidade material do próprio direito; contradições normativas em que uma conduta em abstrato ou em concreto aparece ao mesmo tempo como prescrita e não prescrita, proibida e não proibida, ou até como prescrita e proibida; contradições valorativas, que resultam de uma postura do legislador em não se manter fiel a uma mesma ordem valorativa em todo o ordenamento jurídico; contradições teleológicas, que são aquelas nas quais o legislador prevê determinado fim, mas o meio único e hábil a atingir aquele fim está proibido por outro conjunto de normas; contradições de princípios, ocorre quando há alteração nas orientações supra legais do ordenamento jurídico, isso porque houve modificações nas circunstâncias de fato, das concepções

27 PINDYCK, Robert S.; RUBINFELD, Daniel L. Microeconomia. 4. ed. São Paulo: Makron-Books, 1999. p. 83.

28 ENGISH, Karl. Introdução ao pensamento jurídico. 6. ed. Lisboa: F. Calouste Gulbenkian, 1983. p. 310 e ss. 
políticas, culturais e morais; normalmente ocorre a rejeição dos "velhos" princípios em confronto com os "novos" princípios ${ }^{29}$.

Todavia, seja o conflito motivado economicamente, ou por uma deficiência lógico-legislativa, demanda invariável e necessariamente uma solução.

\subsection{FORMAS DE SOLUÇÃO}

Apesar de o próprio ordenamento jurídico garantir, em alguns casos específicos, direitos contrapostos numa mesma situação - de forma a garantir a licitude dos atos que naquele momento e espaço são contrapostos e inconciliáveis - o mesmo ordenamento pressupõe a regra de coerência, na qual "num ordenamento jurídico não devem existir antinomias", , seja qual for a sua origem.

Assim, apesar de, em abstrato, o ordenamento jurídico ser, em alguns momentos, contraditório, garantindo direitos opostos, em concreto, esta situação é inadmissível ${ }^{31}$.

A colisão em abstrato é indesejável num ordenamento jurídico, porém não é, como afirma Ricardo Luiz Lorenzetti "um requisito sine qua non, mas é uma aspiração; não é só um problema de lógica". ${ }^{32}$ Contudo, na aplicação do ordenamento, isto é, em concreto, o ordenamento jurídico não pode admiti-la, pois o Direito há de ser um sistema, e não um simples agregado de normas ${ }^{33}$.

Para a solução dos conflitos gerados no âmbito interno do ordenamento jurídico, são previstas basicamente duas formas. A primeira, denominada via legislativa, ou ex

29 Vale ressaltar que Claus-Wilheim Canaris (Pensamento sistemático e conceito de sistema na ciência do direito. Tradução de A. Menezes Cordeiro. 2. ed. Lisboa: Calouste Gulbekian, 1996. § 3º, p. 200) afirma que as contradições de princípios apenas são uma forma especial da contradição dos valores fundamentais.

30 BOBBIO, Norberto. Teoria do ordenamento jurídico. 8. ed. Brasília: Editora da UnB, 1996. p. 110.

31 No mesmo sentido, é a lição de Grünhut citado e complementado por Karl Engish (Introdução ao pensamento jurídico, p. 312) para quem a "relativização do dogma da unidade e da coerência (ausência de contradições) da ordem jurídica não afecta propriamente a substância do Direito".

32 Fundamentos do direito privado, p. 424.

33 LUMIA, Giuseppe. Elementos de teoria e ideologia do direito. São Paulo: Martins Fontes, 2003. p. 86. 
$\operatorname{lege} e^{34}$, é aquela na qual o próprio legislador prevê, a priori, a possibilidade conflituosa e determina de antemão qual dos valores materializados em direitos deve prevalecer, ou a solução que se entende justa e possível na hipótese ${ }^{35}$.

Muito comum ao legislador é, no balanço adequado dos valores, prever a prevalência de um, entendido como mais importante e necessário, em detrimento do outro. Na lição de Ricardo Luiz Lorenzetti, deve-se buscar praticar o justo em um nível ótimo; "em alguns casos, isto supõe realizar opções excludentes. Para tanto, nestes casos, o Direito tem proibido algumas condutas, ou há um conflito entre bens não comparáveis, ou trata-se de bens que gozam de uma proteção máxima, não suscetível de restrições”36.

O conflito torna-se mais evidente quando consideramos o movimento de positivação dos direitos fundamentais feito pelo legislador. A concessão de tais direitos é realizada em defesa dos mais importantes valores de uma sociedade, porém, para sua efetiva aplicação e conciliação na prática, esses direitos demandam outras normas, restritivas de seu conteúdo ${ }^{37}$.

Sobre os limites dos direitos fundamentais e a escolha a se fazer sobre direitos concorrentes, leciona Norberto Bobbio:

"são bem poucos os direitos considerados fundamentais que não entram em
concorrência com outros direitos também considerados fundamentais, e que,
portanto, não imponha, em certas situações e em relação a determinadas
categorias de sujeitos, uma opção"38.

É o que ocorre, por exemplo, na proteção do bem de família caso, em que, entre o direito patrimonial de um, o credor, e o direito à moradia do devedor e sua família, preferiu o legislador a proteção da única habitação da entidade familiar, impedindo o credor de se satisfazer sobre aquele bem. A opção é excludente.

34 ZAVASCKI, Teori Albino. Antecipação de tutela e colisão de direitos fundamentais, p. 15.

35 No mesmo sentido é a posição de Edilsom Pereira de Farias em sua obra Colisão de direitos (Porto Alegre: Safe, 1996. p. 94), “... assim, verificada a existência de reserva de lei na constituição para pelo menos um dos direito colidentes, o legislador poderá resolver a colisão comprimindo o direito ou direito restringíveis, respeitando, é claro, requisitos tais como o núcleo essencial dos direitos envolvidos".

36 LORENZETTI, Ricardo Luis. Fundamentos do direito privado, p. 421.

37 CANOTILHO, José Joaquim Gomes. Direito constitucional, 5. ed. Coimbra: Almedina, 1992. p. 647. No mesmo sentido FARIAS, Edilsom Pereira de. Colisão de direitos. Porto Alegre: Safe, 1996. p. 75.

38 BOBBIO, Norberto. A era dos direitos. Rio de Janeiro: Campus, 1992. p. 20. 
O balanço entre valores normatizados em regras e geradores de direitos e deveres é uma constante no processo legislativo.

Em outros casos, porém, ao legislador pareceu ser injusta a escolha excludente, mas, na impossibilidade de conciliação dos dois direitos, escolhe-se um para que prevaleça, garantindo ao outro quantia indenizatória.

Norberto Bobbio já nos alerta sobre a necessidade de proteção do direito limitado ao afirmar: "A dificuldade de escolha se resolve com a introdução dos limites à extensão de um dos dois direitos, de modo que seja em parte salvaguardado também o outro"39.

Nos casos em que a salvaguarda possível é feita na forma de quantia indenizatória previamente definida pelo legislador, verificam-se as hipóteses objeto do presente trabalho. Tem-se como exemplo desta situação a desapropriação na qual, entre o conflito de direitos entre o interesse público e o particular, valoriza-se, por sua importância, o público, surgindo, para o Estado, a obrigação indenizatória do direito ofendido do particular ${ }^{40}$.

Outra forma de solução dos conflitos internos no âmbito do ordenamento jurídico é a via judicial, ou ex iudicio, na qual o judiciário deve solucionar, a posteriori, o conflito. Tem lugar quando não houver regra legislada sobre aquela questão ou quando as regras forem insuficientes para a solução do conflito.

É o caso, por exemplo, da colisão existente entre a "liberdade de expressão e informação" e "a honra, a intimidade, a vida privada e a imagem". Como estes princípios estão em mesmo nível, qual seja o constitucional, e de importância semelhante no plano principiológico, o juiz, fazendo a valoração dos bens envolvidos ao caso particular, com o mínimo de sacrifícios dos direitos contrapostos ${ }^{41}$, deve decidir qual dos direitos deve prevalecer e se à parte contrária, prejudicada pela solução, é devida ou não reparação ${ }^{42}$.

39 BOBBIO, Norberto. A era dos direitos. Rio de Janeiro: Campus, 1992. p. 21.

40 Constituição Federal de 1998, arts. $5^{\circ}$, XXIV, e $182, \S \S 3^{\circ}$ e $4^{\circ}$.

41 FARIAS, Edilsom Pereira de. Colisão de direitos, p. 140.

42 Superior Tribunal de Justiça, Recurso Especial 719.592/AL, Ministro Jorge Scatezzini, em 12/12/2005. RECURSO ESPECIAL - RESPONSABILIDADE CIVIL - DANO MORAL - LEI DE IMPRENSA ACÓRDÃO - OMISSÃO - AFRONTA AO ART. 535 DO CPC - INOCORRÊNCIA - ART. 49 DA LEI N. 5.250/67 - DIREITO DE INFORMAÇÃO - ANIMUS NARRANDI - EXCESSO NÃO CONFIGURADO REEXAME DE PROVA - INADMISSIBILIDADE - SÚMULA 07/STJ - DISSÍDIO JURISPRUDENCIAL - AUSÊNCIA DE SIMILITUDE FÁTICA - RECURSO NÃO CONHECIDO. (...) 2. A responsabilidade civil decorrente de abusos perpetrados por meio da imprensa abrange a colisão de dois direitos fundamentais: a liberdade de informação e a tutela dos direitos da personalidade (honra, imagem e vida privada). A atividade jornalística deve ser livre para informar a sociedade acerca de fatos cotidianos de interesse público, em 
Nesta situação, em que se demanda solução pela via judicial aos conflitos no âmbito do ordenamento jurídico, é relevante a aplicação do princípio da ponderação de bens ou valores ${ }^{43}$, como um critério a orientar o julgador na obtenção de solução ao conflito. Por esse critério, o julgador, na presença de um caso difícil em que os comandos normativos não permitem a mera subsunção, deverá examinar os fatos, as circunstâncias concretas do caso e sua relação com os comandos normativos para, por fim, atribuir pesos aos elementos em disputa ${ }^{44}$. Assim, um ou outro direito deverá ceder até a obtenção do ponto ótimo entre eles, por meio da ponderação dos direitos que estão em jogo ${ }^{45}$.

A ponderação, como aspecto do princípio da proporcionalidade, expressa-se ainda, na lição de Robert Alexy, em três subprincípios: a adequação e a necessidade que visam otimizar a conciliação prática possível à atenção dos direitos e o sub-princípio da proporcionalidade em sentido estrito, que rege-se pela regra "quanto maior o grau de nãosatisfação, ou detrimento, de um princípio, maior deve ser a importância de se satisfazer o outro" 46 .

Todavia, o citado autor ao versar sobre as diferenças entre regras e princípios, reforça, no entanto, os limites aos quais deve-se manter o presente estudo ao afirmar que a ponderação é essencialmente o procedimento de solução de colisão dos princípios, mas "a forma de aplicação de regras não é a ponderação, senão a subsunção" ${ }^{\text {"47 }}$.

observância ao princípio constitucional do Estado Democrático de Direito; contudo, o direito de informação não é absoluto, vedando-se a divulgação de notícias falaciosas, que exponham indevidamente a intimidade ou acarretem danos à honra e à imagem dos indivíduos, em ofensa ao princípio constitucional da dignidade da pessoa humana. 3. No que pertine à honra, a responsabilidade pelo dano cometido através da imprensa tem lugar tão-somente ante a ocorrência deliberada de injúria, difamação e calúnia, perfazendo-se imperioso demonstrar que o ofensor agiu com o intuito específico de agredir moralmente a vítima. Se a matéria jornalística se ateve a tecer críticas prudentes (animus criticandi) ou a narrar fatos de interesse coletivo (animus narrandi), está sob o pálio das "excludentes de ilicitude" (art. 27 da Lei n. 5.250/67), não se falando em responsabilização civil por ofensa à honra, mas em exercício regular do direito de informação. 4. O Tribunal a quo, apreciando as circunstâncias fático-probatórias, é dizer, todo o teor das reportagens, e amparando-se em uma visão geral, entendeu pela ausência de dano moral, ante a configuração de causa justificadora (animus narrandi), assentando, de modo incontroverso, que os recorridos não abusaram do direito de transmitir informações através da imprensa, atendo-se a narrar e a licitamente valorar fatos relativos a prostituição infanto-juvenil, os quais se encontravam sob apuração policial e judicial, obtendo ampla repercussão em virtude da autoridade e condição social dos investigados. Maiores digressões sobre o tema implicariam o reexame da matéria probatória (...).

43 LARENZ, Karl. Metodologia da ciência do direito, p. 574.

44 BARROSO, Luis Roberto. Interpretação e aplicação da Constituição. 6. ed. São Paulo: Saraiva, 2004. p. 360 e ss.

45 LARENZ, Karl. Metodologia da ciência do direito, p. 574.

46 ALEXY, Robert. Ponderação, jurisdição constitucional e representação popular. In: SARMENTO, Daniel; SOUZA NETO, Cláudio Pereira de. A constitucionalização do Direito. Rio de Janeiro: Lúmen Júris, 2007. p. 295 e ss.

47 ALEXY, Robert. Colisão de direitos fundamentais e realização de direitos fundamentais no Estado de direito democrático. Revista de Direito Administrativo, Rio de Janeiro, n. 217, p. 75, 1999. 
Dessa forma, este trabalho limita-se a esboçar alguns estudos sobre o caso específico em que, na primeira forma de solução de conflito no âmbito do ordenamento jurídico, isto é, a via legislativa (ex lege), o legislador determina a prevalência de um direito em relação a outro a ele oposto, porém com a conseqüente obrigação indenizatória do direito ofendido.

Assim, a opção pelo estudo da responsabilidade civil ex lege por conflito de direitos resolve-se, essencialmente pelo processo de subsunção, uma vez que a ponderação dos interesses foi feita pelo legislador ao elaborar a norma a ser aplicada.

Mas esta não é razão para negarmos que o estudo da colisão de direitos em todos os seus aspectos é tema relevante a ser enfrentado pela doutrina. A opção doutrinária decorrente de uma imposição metodológica por um sistema não tão hermético de direito, isto é, mais flexível, visando acompanhar as mudanças da sociedade, preocupado mais com seu conteúdo do que com sua forma, com a sua efetividade do que com sua natureza e fundamentação, valendo-se muitas vezes de princípios como solução metodológica, tornará muito mais comum a ocorrência destes conflitos criados pelo próprio sistema jurídico ${ }^{48}$. É, de certa forma, o preço que se pagará por um direito mais justo. Contudo, obrigará, sempre, uma solução do próprio ordenamento jurídico.

Mesmo por que, em analogia superficial, constatamos que os mecanismos desenvolvidos para avaliações e ponderações da solução dos conflitos de direitos pelos julgadores, em momento posterior à sua ocorrência no âmbito social, em muito podem contribuir e orientar a atividade do legislador, ao tratar previamente de hipóteses que contemplem, também, colisão de direitos. Especialmente se tratar de hipóteses de direitos considerados fundamentais. Nesse sentido, verificamos a aproximação dos raciocínios do legislador e do julgador permitindo que todo o trabalho doutrinário no desenvolvimento de tais mecanismos possam ser aproveitados, por um ou outro, em suas atividades.

Espera-se, por fim, que este estudo traga idéias aos casos em que a solução ao conflito de direitos seja vislumbrada, a priori, pelo legislador, na qual haverá a prevalência de um direito, mas que, no entanto, prejudicará o outro, ao qual, o próprio legislador previu, como regra de justiça, uma indenização ao seu dano.

48 PERLINGIERI, Pietro. Perfis de direito civil. Tradução de Maria Cristina De Cicco. 3. ed. Rio de Janeiro: Renovar, 1997. p. 72. 


\section{A RESPONSABILIDADE - POSIÇÃO SISTEMÁTICA}

\subsection{NOÇÃO DA RESPONSABILIDADE CIVIL POR CONFLITO DE DIREITOS}

Situada a responsabilidade civil ex lege por conflitos de direitos quanto aos limites de sua origem e determinada a sua real função específica, qual seja solucionar a colisão entre dois direitos incompatíveis no plano fático e material, pode-se avançar o estudo para a responsabilidade civil resultante deste conflito.

A responsabilidade civil decorrente de conflitos de direitos nada mais é do que o reequilíbrio de uma situação afetada pelo exercício de outro direito contraposto.

Da solução legislativa para um conflito do próprio ordenamento jurídico, preteriuse um dos direitos envolvidos, mas ao seu titular foi garantido, por juízo de justiça feito pelo legislador, ação indenizatória de seus prejuízos, como forma de compensação.

Este é um caso de responsabilidade no qual, pelo exercício regular de um direito, em atividade lícita, sem abuso nem erro de conduta, ofende-se o direito de outro e a este é devida uma reparação, por imposição do comando legal.

Como exemplo, pode-se citar o caso daquele que, dirigindo prudentemente seu carro, é surpreendido por uma pessoa descuidada que atravessa a rua e, para não atingi-la, direciona seu carro contra outro automóvel estacionado. É o caso de responsabilidade em estado de necessidade, prevista no artigo 929 do Código Civil. Aqui há um choque entre dois direitos reconhecidos pelo ordenamento jurídico: a vida da pessoa e o patrimonial relativo ao carro estacionado. Em situações como esta, estabelece o legislador, caso seja imprescindível a lesão de um dos bens, que se prefira o de menor valor, que neste exemplo seria o carro, pois o bem a ser mantido, por sua importância, é a vida. No entanto, ao que 
sofreu o dano, o proprietário do carro, cabe ação indenizatória contra o motorista, que, por conseguinte, tem regresso contra a pessoa que atravessava descuidadamente a rua ${ }^{49}$. Notese que o motorista não agiu em nenhum momento contra o ordenamento jurídico, ao contrário: seu ato foi apropriado, porém, ao mesmo tempo, não é justo deixar sem reparação o proprietário do carro abalroado.

Esta obrigação pode parecer, prima facie, um paradoxo ao sistema da responsabilidade $\operatorname{civil}^{50}$, pois que: em exercício regular de direito, em atividade plenamente permitida pelo ordenamento jurídico, ou seja, lícita, dever-se-á reparar a alguém. Entretanto, ao contrário, e pelo que foi exposto até aqui, esta responsabilidade é não o paradoxo, mas, sim, a justa solução, entendida pelo legislador, de outro paradoxo criado pelo próprio ordenamento jurídico. Miguel Maria Serpa Lopes ${ }^{51}$ põe a questão em termos, esclarecendo este tipo de posicionamento do legislador ao afirmar que

\footnotetext{
"a cada atentado sofrido pelo homem, seja em relação à sua pessoa física, seja ao seu patrimônio, corresponde uma quebra do equilíbrio patrimonial, cuja inalterabilidade a ordem jurídica tem o dever de manter. Há, por conseguinte, a imperativa necessidade de criar remédios adequados ao restabelecimento deste status quo ante. Como se vê, normalmente a vida do homem deve correr imune de qualquer lesão aos seus direitos, seja qual for a sua natureza".
}

Ou seja, independentemente de sua origem, há de se equilibrar a posição da vítima, buscando a recomposição de sua situação jurídica patrimonial afetada pelo dano sofrido, e mais, "pelo refazimento de sua condição de titular do direito à dignidade constitucionalmente plasmada enquanto valor máximo da pessoa humana, pela imposição do dever indenizatório ao causador do dano" ${ }^{, 52}$.

Reafirme-se, a responsabilidade civil ex lege por conflito de direitos tem por função específica a reparação por critério de justiça e eqüidade determinado pelo legislador, dos prejuízos causados pela ofensa de um direito ou exercício de outro, naquele momento, considerado mais importante ou necessário.

49 Artigo 930 do Código Civil.

50 CAVAliERI FILHO, Sergio. Programa de Responsabilidade Civil. 6. ed. São Paulo: Malheiros, 2006. p. 547.

51 LOPES, Miguel Maria de Serpa. Curso de direito civil. 4. ed. Rio de Janeiro: Freitas Bastos, 1995. v. V, p. 158-159.

52 HIRONAKA, Giselda Maria Fernandes Novaes. Responsabilidade civil e contemporaneidade: retrato e moldura. Revista EPD, São Paulo, Escola Paulista de Direito, ano 1, n. 1, 2005. p. 207. 


\subsubsection{Análise crítica dos conceitos e posições de alguns doutrinadores}

Seja tratando a responsabilidade civil por conflito de direitos como categoria genérica, seja versando sobre uma de suas espécies, alguns doutrinadores já abordaram a situação em tela. A seguir, são analisadas sucintamente as posições e as idéias de alguns deles. Ressaltamos, no entanto, que outros doutrinadores pátrios e estrangeiros serão citados no decorrer deste trabalho.

\subsubsection{Alemães}

Talvez, uma das maiores contribuições para o estudo da categoria objeto deste estudo decorra das lições de Karl Larenz ${ }^{53}$. Este autor, compreende as hipóteses que se apresentam como responsabilidade por conflito de direitos, como um fundamento autônomo do dever de indenizar danos, ao lado do ato ilícito e do risco, afirmando:

"um último grupo de danos imputáveis representam os casos em que a lei, em consideração ao interesse predominante, permite um ataque contra o direito protegido 'erga omnes, sempre que concorram circunstâncias muito especiais; impõe, desta forma, ao titular um dever de tolerar ou lhe nega as faculdades de defesa que em outros casos lhe são dadas; mas se reconhece, em compensação pela perturbação suportada, uma pretensão de indenização de danos". 54

Assim, conceituando a questão na visão daquele que sofre o prejuízo, Karl Larenz afirma "é sempre pressuposto que um direito tenha sido perturbado e que o titular do mesmo deva suportar excepcionalmente esta perturbação" ${ }^{, 55}$, mas ao mesmo tempo deve-se

53 Derecho de obligaciones, $\S 72$, p. 690.

54 LARENZ, Karl. Derecho de obligaciones, $§ 72$, p. 690. No original: "un último grupo de daños imputables representan los casos en que la ley en consideración al interés predominante de otro, permite un ataque contra el derecho protegido 'erga omnes', siempre que concurran circunstancias muy especiales; impone, por tanto, al titular un deber de tolerar o le niega las facultades de defensa en otro caso dadas; pero se le reconoce, en compensación por la perturbación soportada, una pretensión de indemnización de daños”.

55 LARENZ, Karl. Derecho de obligaciones, § 72, p. 690. No original: "es siempre presupuesto que un derecho haya sido perturbado y que el titular del mismo haya de soportar excepcionalmente esa perturbación”. 
"lhe conceder uma pretensão de indenização mediante a qual se restabelece o justo equilíbrio entre ambos interesses que chocam-se em colisão",56.

A questão é exposta por Karl Larenz em seus mais exatos termos: a autonomia do fundamento de reparação, o conflito entre os direitos, a prevalência de um e o dever de tolerar a ofensa do outro e, por fim, a obrigação indenizatória que é a compensação do dano.

Enneccerus Lehmann, em pesquisa semelhante sobre os fundamentos da responsabilidade civil, encontra esta categoria e a denomina intromissão consentida na esfera jurídica alheia, citando como exemplo o § 904 do Bürgerliches Gesetzbuch, o Código Civil Alemão ${ }^{57}$ (estado de necessidade ofensivo do direito de vizinhança).

\subsubsection{Portugueses}

O Código Civil português, em seu artigo 335, trata diretamente da colisão de direitos, admitindo assim a possibilidade, bem como oferecendo guias à sua solução. É o dispositivo legal:

"Artigo 335 Havendo colisão de direitos iguais ou de mesma espécie, devem os
titulares ceder na medida do necessário para que todos produzam igualmente o
seu efeito, sem maior detrimento para qualquer das partes. 2. Se os direitos
forem desiguais ou de espécie diferente, prevalece o que deva considerar-se
superior".

Note-se, no entanto, que o artigo em si não prevê a possibilidade de indenização à parte prejudicada. Contudo, a positivação do conflito e a indicação da forma de como superá-lo influenciaram a produção doutrinária daquele país.

56 LARENZ, Karl. Derecho de obligaciones, p. 691. No original: "concederle una pretensión de indemnización mediante la cual se restablece el justo equilibrio entre ambos intereses que se hallan entre sí en colisión".

57 ENNECERUS, Ludwig e LEHMANN, Heinrich. Lehrbuch des Bürgerlichen Rechts, Band 2: Recht der Schuldverhältnisse. Tübingen: Tübingen, 1958. p. 61. 
Carlos Alberto da Mota Pinto denomina a categoria em estudo como "responsabilidade por actos lícitos ou intervenções lícitas"58 e complementa discorrendo que:

\begin{abstract}
"apesar da situação parecer, prima facie, paradoxa, surge nos casos em que é necessário compensar o sacrifício de um interesse menos valorado na composição de um conflito teleológico, porque uma prevalência absoluta e total do interesse oposto será injusta. Assim, mesmo sendo a atividade do agente secundum jus, pareceu excessivo não dar à pessoa sacrificada uma reparação. ${ }^{, 59}$
\end{abstract}

Ressalte-se sua preocupação em demonstrar que não se trata de um paradoxo do ordenamento jurídico - que pode haver sido gerado por visão binária da responsabilidade civil $^{60}-$, mas a solução de um conflito teleológico.

Pode-se opor a Carlos Alberto da Mota Pinto apenas no que se refere à nomenclatura por ele utilizada para a categoria em questão. A denominação "responsabilidade civil por actos lícitos" não parece a mais adequada. Isso porque, apesar deste tipo de responsabilidade surgir em atividade lícita, ela não encerra toda responsabilidade decorrente de atos lícitos. Os casos de responsabilidade objetiva por risco são, em síntese, também decorrentes de atividade permitida pelo direito, isto é, lícitas. Assim, haveria uma ampliação do objeto definido abrangendo também as hipóteses de responsabilidade por risco.

Além disso, trata-se de uma questão de ênfase. Parece mais preciso conceituar a questão como responsabilidade ex lege decorrente do conflito de direitos, entendendo a atividade lícita como elemento incidental à questão, posto que, essencialmente, a responsabilidade surge do conflito entre direitos e não da licitude da conduta, que, em si, e destacada do conflito entre direitos, não gera responsabilidade.

Outro doutrinador português, João Matos Antunes Varela, em sua obra Das obrigações em geral, ${ }^{61}$ discorre sobre o que ele também nomeia como "responsabilidade por factos lícitos". Em sua concepção, este tipo de responsabilidade ocorre pois:

58 Teoria geral do direito civil. 3. ed. Coimbra: Editora Coimbra, 1994. p. 122.

59 MOTA PINTO, Carlos Alberto da. Teoria geral do direito civil. 3. ed. Coimbra: Editora Coimbra, 1994. p. 122.

60 Essa visão binária decorre da concepção simplista de que todo ilícito deve ser indenizado e que todo lícito deve ser tolerado. Idéia esta que se sustenta pela crença, pois se nada possui de científico, de que o ordenamento jurídico não possui antinomias em abstrato. Cf. Cap. 1, item 1.2 (Antinomias - no início).

61 VARELA, João Matos Antunes. Das obrigações em geral. 10. ed. Coimbra: Almedina, 2003. 
"o acto (lesivo) pode ser lícito, porque visa satisfazer um interesse coletivo ou interesse qualificado de uma pessoa de direito privado. Mas pode, ao mesmo tempo, não ser justo (no plano da justiça comutativa ou no da distributiva) que se sacrifique, sem nenhuma compensação, os direitos de um ou mais particulares ou bens de outra pessoa", ${ }^{, 2}$.

Em relação à nomenclatura, os mesmos comentários feitos ao professor Carlos Alberto da Mota Pinto podem ser retomados.

João Varela entende este instituto fundado direta e exclusivamente em um juízo de justiça, porém deixa a entender não crer em sua sistematização, pois valoriza sua casuística afirmando que "a lei preferiu deixar a disciplina de cada uma delas (situações deste tipo) entregue ao seu condicionalismo específico",63.

Outro doutrinador que abordou a questão, mesmo que de forma sucinta, foi Inocêncio Galvão Telles, quando trata das categorias de responsabilidade extraobrigacional. Neste tópico, ao lado da responsabilidade por ato ilícito e da responsabilidade pelo risco, entende este doutrinador a existência de uma "responsabilidade por acto lícito" ${ }^{, 64}$. Afirma o autor:

\footnotetext{
"trata-se de acto que a lei consente por o considerar justificado em atenção à natureza do interesse que visa satisfazer. Mas desse acto resulta prejuízo para outrem. E a lei considera de justiça que o titular daquele interesse, podendo embora realizar o acto, não deixe contudo de indemnizar o terceiro pelos danos que lhe cause" 65 .
}

Conceitua, desta forma, o instituto pela visão daquele que causa prejuízo e considera a indenização uma questão de justiça. O ponto mais importante em suas idéias é a clara divisão tripartida do fundamento na obrigação de reparar.

Em relação à nomenclatura utilizada por Inocêncio Galvão Telles, pode-se proferir a mesma crítica feita aos outros estudiosos apresentados nesta parte.

62 VARELA, João Matos Antunes. Das obrigações em geral, § 164, p. 573.

63 VARELA, João Matos Antunes. Das obrigações em geral, § 164, p. 573.

64 TELLES, Inocêncio Galvão. Direito das obrigações. 7. ed. Coimbra: Editora Coimbra, 1997. p. 214.

65 TELLES, Inocêncio Galvão. Direito das obrigações, p. 214. 


\title{
2.1.1.3 Italianos
}

No estudo da responsabilidade civil por seu real fundamento, o dano, Adriano de Cupis busca, como primeira questão, diferenciar os danos com relevância jurídica e aqueles que não interessam ao ordenamento jurídico. Os primeiros são classificados quanto à sua licitude e dividem-se em danos antijurídicos e danos não-antijurídicos.

Quanto à categoria dos danos não-antijurídicos, isto é, danos lícitos, Adriano de Cupis versa: "o direito considera um interesse digno de prevalecer, preocupando-se, por outro lado, em estabelecer conseqüência apta a compensar o sujeito que teve seu interesse sacrificado" e continua "a reação a isso correspondente não é uma sanção, pelo simples motivo de que o direito não visa garantir que um direito prevaleça sobre outro, mas, tãosomente visa compensar o sujeito que teve seu interesse sacrificado" 66 .

A linha argumentativa de Adriano de Cupis demonstra a necessidade de um dos direitos prevalecer sobre outro, porém com a conseqüente indenização.

Domenico Rubino $^{67}$, de forma precisa, aponta que:

\begin{abstract}
"sustentar o argumento de que onde há um ressarcimento deve necessariamente preexistir uma obrigação e um direito subjetivo (ou um interesse legitimo), significa incorrer em uma petição de princípio ao se excluir, a priori, por falso preconceito, a categoria do ato lícito danoso, que ao invés, é rigorosamente deduzida do direito positivo posto, frente à impossibilidade de detectar-se, em cada caso, uma obrigação preexistente ao ressarcimento, que foi violada com o evento danoso."
\end{abstract}

Guido Alpa e Mário Bessone também contemplam a categoria dos atos lícitos danosos e afirmam:

66 DE CUPIS, Adriano. Il danno: teoria generale della responsabiltà civile. 2. ed. Milão: Giuffrè, 1966. v. 1, nota 34, p. 20. No original: "il diritto consideri un determinato interesse degno di prevalere, preoccupandosi, d'altra parte, di stabilie conseguenze atte a compensare il soggetto dell'interesse sacrificato" e "la reazione ad esso corrispondente non è una sanzione, per il semplice motivo che com essa il diritto intende non già garantire la prevalenza di un interesse, ma, bensì, compensare il soggetto dell'interesse da esso stesso sacrificato".

67 RUBINO, Domenico. La fattispecie e gli effetti giuridici preliminari. Milão: Giuffrè, 1939. p. 205. No original: "L'irrigidirsi nell'argomentare che, là dove è ammesso un risarcimento, ivi debbano necessariamente preesistere un obbligo ed un diritto subiettivo (o un interesse legittimo), significherebbe avvolgersi in una petizione di principio, ed escludere a priori, per falsi preconcetti, la categoria dell'atto lecito dannoso, che invece è rigorosamente indotta daí dati di diritto positivo, di fronte alla impossibilità di rinvenire, in taluni casi, un obbligo preesistente al risarcimento e violato col contegno dannoso." No mesmo sentido, ver DE CUPIS, Adriano. Il danno. nota 34, p. 20. 


\begin{abstract}
"Tem-se defendido que nem todo dano é ressarcível: e que se deve considerar tão-somente o dano derivado de um ato ilícito. O legislador considera, todavia, hipóteses, caso a caso, do ato que, mesmo sendo lícito, resulta dano a um terceiro, gerando, portanto, a questão da reintegração" ${ }^{\text {"68 }}$.
\end{abstract}

Sobre a sistematização de tais casos como hipóteses de responsabilidade civil, os citados autores lecionam: "É, todavia, comum o entendimento que tal hipótese, própria porque relativa ao ato lícito, exorbita à área de aplicação da regra de responsabilidade civil. Tais opiniões, todavia, se fundam em uma razão nominalista, e portanto não podem ser aceitas. Se pensa na verdade que a regra de responsabilidade é aplicável somente ao fato danoso que comporta um ressarcimento, mas não ao fato lícito que não é punível e que comporta somente uma mera indenização. Se todavia se supera a concepção tradicional, que introduz na regra de responsabilidade civil um instrumento punitivo do ato contrário à norma jurídica, e se considera a disciplina da responsabilidade como um corpo de regras destinado a prescrever diretivas para o ressarcimento do dano (exaltando, portanto, a citada função ressarcitória), também o ato lícito danoso pode reentrar na área de aplicação do artigo $2.043^{69, "}$ e ss. do Código Civil" ${ }^{\prime 70}$.

68 ALPA, Guido; BESSONE, Mario. Atipicità dell'illecito: parte prima. 2. ed. Milano: Giuffrè Editore: 1980. p. 96 e 97. No original: Si è precisato Che non tutti i danni sono risarcibili: e che si debbono considerare tali soltanto $\mathrm{i}$ danni che derivano da um atto illecito.Il legislatore prende tuttavia in considerazione alcune ipotesi sintomatiche di atti Che, pur essendo leciti, risultano dannosi per i terzi, e investono pertanto questione di reintegrazione".

$69 \mathrm{O}$ autor, por óbvio, refere-se ao Código Civil italiano. Esclareça-se que o artigo 2.043 é tratado como fundamento tradicional e consolidado da responsabilidade civil, em que pese tratar-se do ressarcimento decorrente do fato ilícito.

70 ALPA, Guido; BESSONE, Mario. Atipicità dell'illecito, p. 97. No original: "È tuttavia comune opinione che tali ipotesi, próprio perché relative ad atti leciti, esorbitano l'area di applicazione delle regole di responsabilità civile. Tale opinione, tuttavia, si Fonda su uma ragione nominalistica, e quindi non accettabile. Si ritiene infatti Che lê regole di responsabilità siano applicabili solo ai fatti danosi Che comportano um risarcimento, ma non ai fatti leciti Che non sono sanzionati e Che comportano soltanto uma mera "indennità. Se tuttavia si supera la concezione tradizionale, Che intravvede nelle regole di responsabilità civil elo strumento sanzionatorio degli atti contrari alle norme giuridiche e si considera inveceladisciplina della responsabilità come un corpo di regole destinato a predispore direttive per il risarcimento del danno (esaltandone pertanto la c.d. funzione risarcitoria), anche gli atti leciti dannosi possono rientrate nell'area di aplicazione degli artt.2043 ss. cod. civ". 


\subsubsection{Brasileiros}

$\mathrm{Na}$ doutrina nacional, Alvino Lima, versando sobre os artigos 1.519, $1.520 \mathrm{e}$ 1.540 do Código Civil de $1916^{71}$, afirma que: "se trata da responsabilidade decorrente de um lícito, no exercício regular de direito ${ }^{72}$, , e complementa, “impossível seria pretender que o fundamento desta responsabilidade repouse a culpa, pois se esta nada mais é do que um erro de conduta, incompatível se torna com o exercício de um direito ${ }^{73}$ ".

Demonstra-se assim o caráter objetivo deste tipo de responsabilidade civil, excluindo-a de qualquer sistematização no âmbito da responsabilidade subjetiva.

Orlando Gomes ${ }^{74}$, versando sobre as hipóteses de responsabilidade sem culpa, afirma serem duas as suas razões: " $1^{a}$ ) a consideração de certas atividades do homem criam um risco especial para os outros", que se conhece como hipóteses de responsabilidade por riscos, e " $2^{\mathrm{a}}$ ) a consideração de que o exercício de determinados direitos deve implicar a obrigação de ressarcir os danos que origina", as quais são objeto deste trabalho e é denominada responsabilidade civil por conflito de direitos.

Sobre este segundo tipo, são suas hipóteses "a) o ato praticado em estado de necessidade ou legítima defesa; b) atos praticados no exercício de um direito real, notadamente de vizinhança",75.

Para a explicação do fundamento deste tipo de responsabilidade afirma Orlando Gomes: "Nestes casos o ato é lícito, estando expressamente autorizada sua prática na lei, mas, com fundamento na eqüidade, impõe-se ao agente da obrigação de indenizar danos presumidos. Assim, é obrigado a repará-los sem culpa"76.

71 Correspondentes aos artigos 929 e 930 do Código Civil vigente.

72 LIMA, Alvino. Culpa e risco. 2. ed. São Paulo: RT, 1998. p. 303.

73 LIMA, Alvino. Culpa e risco, p. 303.

74 Obrigações. 10. ed. Rio de Janeiro: Forense, 1995. § 216 e ss., p. 307 e ss. Vale ressaltar que após a promulgação do Código Civil vigente, foram suprimidos, pelo atualizador da obra de Orlando Gomes, os capítulos referentes à Responsabilidade Civil visando à elaboração de obra específica sobre este assunto, ainda no prelo. Por esse motivo, nos valemos, neste tema, da $10^{\mathrm{a}}$ edição para as lições de Orlando Gomes.

75 GOMES, Orlando. Obrigações. 10. ed., p. 308.

76 GOMES, Orlando. Obrigações. 10. ed., p. 308. 
Por fim, como hipótese deste instituto jurídico, enumera os seguintes artigos do Código Civil de 1916: “a) arts. 160, 1.519, 1.520 e 1.540; b) art. 560; c) art. 564; d) art. 567; e) art. 587; f) art. 541. ${ }^{77, " ~ A ~ p o s i c ̧ a ̃ o ~ d o ~ j u r i s t a ~ b a i a n o ~ e ́ ~ m u i t o ~ s o ́ b r i a ~ e ~ p o n d e r a d a . ~}$

Francisco Cavalcanti Pontes de Miranda $^{78}$, em seu vocabulário cuidadoso e próprio, informa que, no caso do artigo 160, inciso II, do Código Civil de $1916^{79}$, em que pese ser esta uma "pré-exclusão de contrariedade ao direito", a obrigação surge do "ato-fato jurídico" que atende ao "princípio do interesse mais relevante". Demonstra o autor a desconsideração da vontade subjetiva do agente, valorizando-se mais a sua conduta e o seu resultado (ato-fato) e, principalmente, a graduação dos valores envolvidos.

Carlos Roberto Gonçalves $^{80}$ denomina a categoria aqui estudada como "responsabilidade extracontratual decorrente de fatos permitidos por lei" e enumera como exemplos os artigos 929 (estado de necessidade), 1.285 (passagem forçada) e 1.313 (entrada necessária e danosa a terreno vizinho para execução de serviços necessários) todos do Código Civil de 2002.

Sérgio Cavalieri Filho, mesmo em concepção e sistematização diversa da ofertada neste estudo, afirma:

\footnotetext{
“muitas são as hipóteses em que a lei concede um direito mas condiciona o seu exercício, apesar de legítimo, à reparação dos eventuais prejuízos sofridos por terceiros. Assim, por exemplo, na desapropriação, na servidão e no estado de necessidade" $" 81$.
}

Sobre as hipóteses de aplicação, prossegue o mencionado autor:

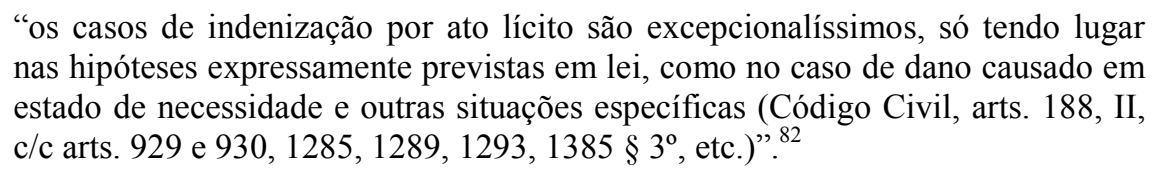

Apesar de a maioria dos autores pátrios apresentar aplicações desta categoria na esfera do Direito Privado, alguns vão além, visualizando, ainda, aplicações para este instituto no campo do Direito Público.

7 GOMES, Orlando. Obrigações. 10. ed., p. 308.

Tratado de direito privado. Campinas: Bookseller, 2000. t. II, § 163, p. 234.

79 Correspondente ao artigo 188, inciso II, do Código Civil vigente.

80 Responsabilidade civil. 8 ed. São Paulo: Saraiva, 2003. p. 29.

81 CAVALIERI FILHO, Sergio. Programa de responsabilidade civil. p. 551.

82 CAVALIERI FILHO, Sergio. Programa de responsabilidade civil, p. 31. 
Elcio Trujillo, apoiado na doutrina nacional e estrangeira, demonstra de forma cabal a presença de responsabilidade por ato lícito decorrente de atividade do Estado. Esclarece este jurista que "será indenizável quando o ato embora lícito, motivado pelo interesse público, causar um prejuízo especial e anormal [ao particular]” ${ }^{\prime 83}$. Assim, no conflito lícito de direitos entre o particular e o Estado, este último, representando o interesse público, prevalecerá e exercerá seu direito, mas, ao mesmo tempo, assume a obrigação de compensar os danos sofridos pelo particular.

Elcio Trujillo vai além, afirmando: "a responsabilidade decorrente do ato ilícito, o dever de reparar é a contrapartida da violação da legalidade; no caso da responsabilidade motivada pelo ato lícito danoso, temos que o fundamento é a idéia da igualdade dos cidadãos perante os encargos públicos" ${ }^{\$ 84}$. Demonstra assim não haver confusão entre a responsabilidade por culpa e os casos de responsabilidade por conflito de direitos e que o fundamento desta última categoria, quando se referir a sacrifício de direitos por imposição pública, é a igualdade e a divisão dos encargos de atos que visam o bem da coletividade.

Percebe-se uma diferença fundamental entre a responsabilidade civil por conflito de direitos no âmbito dos direitos público e privado. Enquanto no direito privado o fundamento reside na igualdade entre os sujeitos da relação, sendo tomado por injusto que o direito de um dos iguais prevaleça sem que seja devida reparação ao outro, no direito público, o fundamento está não na igualdade entre os sujeitos, posto que o interesse público pretere o privado, mas na insuportabilidade por um sujeito dos ônus pelos benefícios que toda a coletividade usufruirá ${ }^{85}$.

Outra hipótese de aplicação deste instituto no campo do direito público, no direito nacional, refere-se à indenização decorrente do exercício da tutela jurídica como a concessão de medidas cautelares prevista no inciso I do artigo 811 do Código de Processo Civil $^{86}$.

83 TRUJILLO, Elcio. Responsabilidade do estado por ato lícito. Leme: LED, 1996. p. 101.

84 TRUJILLO, Elcio. Responsabilidade do estado por ato lícito, p. 105.

85 No mesmo sentido, é a posição do jurista lusitano Luiz da Cunha Gonçalves. (Tratado de direito civil. 2. ed. São Paulo: Max Limonad, 1956. v. XII, t. I, § 1.858, p. 390).

86 Artigo 811 do Código de Processo Civil: "sem prejuízo do disposto no art. 16, o requerente do procedimento cautelar responde ao requerido pelo prejuízo que lhe causar a execução da medida: I - se a sentença no processo principal lhe for desfavorável." 
Humberto Theodoro Júnior argumenta neste sentido quando, ao discorrer sobre o artigo 811 do Código de Processo Civil, afirma:

"tudo se passa a semelhança do ato danoso praticado em estado de necessidade. $\mathrm{O}$ agente tinha o direito reconhecido de praticá-lo, mas se a vítima não tinha o dever de suportar o prejuízo, cabe ao agente proceder ao competente ressarcimento, embora tenha agido na licitude". ${ }^{87}$

Como se observa, presentes os requisitos do artigo 811 do Código de Processo Civil, é permitido à parte obter tutela cautelar para proteção do objeto do processo, porém, vindo no processo principal sentença posterior em sentido contrário, não deve aquele que teve dano com a concessão da cautela suportar este ônus processual, surgindo, então, a obrigação reparatória descrita no artigo mencionado.

Cabe ressaltar tratar-se este de um conflito entre direitos no plano meramente processual. Os valores em conflito são: o direito à efetividade da jurisdição ${ }^{88}$ versus a segurança jurídica ${ }^{89}$. Deste confronto, o legislador, a priori, previu, no artigo 811 , inciso I, do Código de Processo Civil, que deve prevalecer o direito à efetividade da jurisdição, concedendo a medida cautelar necessária ao resultado prático efetivo do processo, porém, caso a sentença final seja reversa, isto é, aquele que se beneficiou da medida cautelar o fez injustamente, deverá indenizar aquele que a suportou indevidamente, por regra de justiça.

Verifica-se assim que o tratamento dado pelos citados doutrinadores, em que pesem as divergências, apresenta elementos comuns, especialmente se considerarmos as hipóteses apresentadas, o que é o objeto deste estudo.

87 THEODORO JR., Humberto. Processo cautelar. 23. ed. São Paulo: Leud, 2006. p. 186.

88 Por direito à efetividade da jurisdição se compreende, à semelhança de Teori Albino Zavascki, todo o "conjunto de direitos e garantias que a Constituição atribuiu ao indivíduo que, impedido de fazer justiça por mão própria, provoca a atividade jurisdicional para reivindicar bem da vida de que se considera titular" (Antecipação de tutela e colisão de direitos fundamentais, p. 15).

89 Constituição Federal, artigo $5^{\circ}$, inciso LIV. "ninguém será privado da liberdade ou de seus bens sem o devido processo legal". 


\subsection{A QUESTÃO TERMINOLÓGICA}

Um cuidado especial deve ser tomado com a linguagem na indicação de uma categoria sob a qual não há consenso estabelecido tradicionalmente. Esta linguagem deve expressar com clareza, por meio da adequada utilização dos termos, a categoria em estudo, e apenas ela, afastando qualquer ampliação ou restrição indesejável.

Para tanto, esta categoria merece uma análise de suas diferentes denominações.

Como visto ${ }^{90}$, principalmente quanto aos doutrinadores portugueses, é comum a denominação "responsabilidade civil por atos lícitos" para esta categoria. No entanto, o uso de tais termos não revela o verdadeiro fundamento da responsabilidade em questão. A obrigação indenizatória surge da concorrência prática entre direitos contrapostos e nunca em virtude da licitude do ato, o que em si, é, em princípio, uma excludente da responsabilidade subjetiva. Denominar esta obrigação como responsabilidade por ato lícito é, portanto, valorizar uma característica acessória desta responsabilidade e não a sua essência, qual seja a opção do legislador, por critério de justiça, na solução de uma colisão entre direitos.

Em segundo lugar, porque uma responsabilidade por ato lícito abarcaria, além das situações em tela, os casos de responsabilidade objetiva por risco, no qual se indeniza também pelo exercício de uma atividade lícita que causa dano, mas que não se confunde com a responsabilidade civil pelo conflito de direitos, como demonstrar-se-á no Tópico 2.3.5.

Os dois institutos, em que pese serem as espécies do gênero responsabilidade objetiva $^{91}$, isto é, sem culpa, diferem entre si, sendo necessário extremá-los em sua nomenclatura: um, a responsabilidade pelo risco, o outro, a responsabilidade por conflito entre direitos.

Desta forma, seria cientificamente mais correto a denominação "responsabilidade civil ex lege decorrente do conflito de direitos" expressando por meio desta nomenclatura o fundamento da obrigação indenizatória, como ocorre com as outras categorias da responsabilidade civil: a responsabilidade por culpa e a responsabilidade pelo risco.

90 Cf. neste capítulo, item 2.1.1.2 Portugueses.

91 Cf. Cap. 2.3.4 deste trabalho. 
Evitou-se, também, a denominação de dano lícito ou não-antijurídico a esta categoria, como o fazem os italianos por influência de Adriano de Cupis, pois entende-se que o dano, em si, não possui, e nem deve possuir, adjetivos. Como elemento constituinte da parte objetiva da responsabilidade civil, não tem sua natureza alterada pela conduta do agente, seja ela lícita ou ilícita. Ele simplesmente é.

Visando também dissipar confusões, esclareça-se que o vocábulo ex lege utilizado para denominar o tipo da responsabilidade civil não indica que a fonte da obrigação seja a lei, como seria se fosse adotada a tradicional bipartição das fontes das obrigações em "contrato" e "lei" "92. Não nos filiamos a esta posição, uma vez que a fonte das obrigações sempre é um fato jurídico ${ }^{93}$.

Nessa concepção, o vocábulo ex lege vinculado à responsabilidade civil por conflito de direitos indica exclusivamente que esta se refere à solução dada pelo legislador ao conflito de direitos, em oposição à denominada responsabilidade ex iudicio por conflito de direitos, em que a solução é oferecida pelo julgador.

Ainda no âmbito terminológico, especula-se, por mero rigor, a proposta de tratar os sujeitos envolvidos em uma obrigação indenizatória por danador, para o agente, e por danado, danificado para o sujeito passivo.

Estar-se-ia, dessa forma, nomeando os atores da responsabilidade civil adequadamente, com real fundamento, o dano. Substituir-se-iam, assim, os conceitos de autor ou culpado (pólo ativo) e vítima (pólo passivo), que refletem apenas uma concepção subjetivo-culposa de responsabilidade civil, e que se tornam inadequados nos casos de responsabilidade objetiva.

Resguarda-se, porém, de utilizar essas sugestões de denominações em virtude de seus significados populares, barreira que somente se venceria com a utilização científica disseminada dos termos. Assim, prefere-se a utilização do binômio responsável, ao agente e prejudicado, ao que suporta o dano, para denominar os atores da responsabilidade civil.

92 NORONHA, Fernando. Direito das obrigações. São Paulo: Saraiva, 2003. v. 1, p. 343 e ss.

93 NORONHA, Fernando. Direito das obrigações, v. 1, p. 345. 
Por fim, esclarece-se que apesar de se admitir a hipótese de responsabilidade civil por conflito de direitos, tanto pela via legislativa quanto pela judicial, utilizar-se-á, neste estudo, por conveniência prática, a expressão "responsabilidade por conflito de direitos" para expressar a responsabilidade na modalidade ex lege, salientando que, quando se tratar da hipótese ex iudicio, esta denominada expressamente.

\subsection{NATUREZA JURÍDICA E POSIÇÃO NO SISTEMA DA RESPONSABILIDADE CIVIL}

Em um primeiro momento, cumpre questionar a natureza jurídica da responsabilidade civil por conflito de direitos, enquadrando-a no sistema da responsabilidade civil e afirmando sua essência. Desta forma, busca-se determinar suas "relações externas" com outros institutos a ela relacionados.

Uma análise cuidadosa deve ser feita para qualificar este instituto em todos os novos pressupostos, princípios e conceitos incorporados ao sistema de responsabilidade civil, principalmente nas últimas décadas, como as noções de prevalência do dano, a preocupação com a posição daquele que suportou o dano, e a mitigação da função punitiva da responsabilidade civil $^{94}$.

Posteriormente, passa-se à análise da natureza extracontratual do instituto, em que pesem as possibilidades da categoria também admitir a origem contratual. Em seguida, analisa-se sua natureza objetiva, excluindo-a do âmbito de qualquer análise de culpa, centrada fundamentalmente no dano. Por fim, a independência da responsabilidade decorrente do conflito de direitos como fundamento autônomo da responsabilidade civil. Com isso, pretende-se um enquadramento da matéria no sistema da responsabilidade civil.

94 MARIN, Rubens Leonardo. Dos sentidos da responsabilidade civil no Código Civil de 2002 e sua correlação aos tipos. In: TARTUCE, Flávio; CASTILHO, Ricardo (Org.) Direito civil: direito patrimonial e direito existencial. São Paulo: Método, 2006. p. 425 e ss. 


\title{
2.3.1 Novas concepções sobre responsabilidade civil
}

Como nos informa o ilustre jurista Louis Josserand ${ }^{95}$, o homem antigamente, com seu modo de vida mais simplificado, "se sentia em segurança, na rua, na oficina ou na loja", e os acidentes eram tratados como "desgraças naturais" às quais a ninguém se podia pedir contas. No entanto, hodiernamente, 'fiéis' à recomendação de Friedrich Nietzsche ${ }^{96}$, "vivemos perigosamente e, cada vez mais intensamente", sujeitos a possibilidade de sofrer mais danos, além do fato de o homem contemporâneo possuir um domínio muito maior sobre a natureza, sendo responsável por grande parte dos acontecimentos que se refletem em seus semelhantes. Desprovido da segurança material e ciente da existência de um possível responsável para o dano sofrido, os homens buscam cada vez mais a segurança jurídica.

Mais diretamente ao tema em estudo, Washington de Barros leciona:

\begin{abstract}
"Os novos inventos, a intensidade da vida e a densidade das populações aproximam cada vez mais os homens, intensificando suas relações, no plano real e virtual, o que acarreta um aumento vertiginoso de motivos para a colisão de direitos" $"$.
\end{abstract}

A estas alterações sociais o instituto responsabilidade civil não ficou inerte. Ao contrário, sofreu alterações de monta neste último século ${ }^{98}$. A mais importante, sem dúvida alguma, foi a derrocada do primado da culpa como fundamento único da obrigação indenizatória, dando lugar ao dano como centro metodológico do instituto.

Não se sustentava a reparação apenas nos casos em que havia culpa. Esta concepção de responsabilidade civil somente refletia uma postura de um período individualista "coerente com o modelo do homem empreendedor e protestante do início do capitalismo" $" 99$ ou ainda uma concepção religiosa e moral assentada sobre o binômio culpapunição $^{100}$. Na lição de Alvino Lima,

95 Evolução da responsabilidade civil. Revista Forense, v. LXXXVI, jun. 1941, p. 53.

96 Como é, por exemplo, a presente em NIETZSCHE, Friedrich Wilhelm. Humano demasiado humano. São Paulo: Companhia das Letras, 2000. § 638, p. 306.

97 MONTEIRO, Washington de Barros. Curso de direito civil. 35. ed., São Paulo: Saraiva, 2007. v. 5, p. 500.

98 HIRONAKA, Giselda Maria Fernandes Novaes. Responsabilidade pressuposta, p. 120.

99 LORENZETTI, Ricardo Luis. El sistema de la responsablidad civil ¿Una deuda de responsabilidad, un crédito de indemnizacíon o una relacíon jurídica? Ajuris, Porto Alegre, n. 63, 1995, p. 171. No original: "coherente com el modelo del hombre emprendedor y protestante del capitalismo temprano". Orlando Gomes (Introdução ao direito civil. 18. ed. Rio de Janeiro: Forense, 2002. v. 1, p. 91) ressalta que a culpa como fundamento da 


\begin{abstract}
"O entrechoque, entretanto cada vez mais crescente de interesses, aumentando as lesões de direito em virtude da densidade progressiva das populações (...); a multiplicação indefinida das causas produtoras do dano advindas das invenções criadoras de perigos, (...). a necessidade de se proteger a vítima, assegurando-lhe a reparação do dano sofrido (...), não podiam deixar de influenciar no espírito e na consciência do jurista. Era imprescindível rebuscar um novo fundamento à responsabilidade extracontratual, que melhor resolvesse o grave problema da reparação dos danos, de molde a se evitarem injustiças que a consciência jurídica e humana repudiavam!"101.
\end{abstract}

Retomou-se em sua completude, no âmbito da responsabilidade civil, o princípio romano do neminem laedere, isto é, a proibição de ofender ${ }^{102}$, independentemente do elemento culpa ${ }^{103}$ introduzido, talvez, pela Lex Aquilia ${ }^{104}$, ou talvez por interpolações dos glosadores da Idade Média sobre a referida Lei.

O dano ressurge como primeiro elemento indicador de reparação, cabendo hoje a pesquisa sobre quais os danos indenizáveis e os não indenizáveis. Reafirma-se, não é a culpa ou o risco que geram indenização, mas é após a ocorrência do dano que se fará uma análise de tais condutas. Os danos aos quais se entende, por critério de justiça, ser devida a reparação, são os que interessam ao sistema da responsabilidade civil.

Confirma-se, assim, o princípio constitucional do dever geral de solidariedade e de justiça distributiva dispostos no artigo $3^{\circ}$, incisos I e III, da Constituição Federal ${ }^{105}$, que, como objetivos fundamentais da República, concretizam-se pelo amplo atendimento ao prejudicado por dano e pela aplicação do neminem laedere, como dever geral de não lesar os outros ${ }^{106}$.

O critério para se diferenciar um dano indenizável de um não indenizável, hoje, como se objetiva demonstrar neste estudo, é tripartite, ou seja, três são os fundamentos da obrigação indenizatória: os danos originários de uma conduta ilícita, os danos decorrentes de uma atividade lícita, porém de risco à sociedade, e os danos resultantes de uma colisão

responsabilidade civil decorre de uma concepção individualista do direito, em que todo dever jurídico resulta de uma vontade individual.

${ }^{100}$ HIRONAKA, Giselda Maria Fernandes Novaes. Responsabilidade pressuposta, p. 34 e 60.

101 LIMA, Alvino. Culpa e risco, p. 114.

${ }_{102}$ PONTES DE MIRANDA, Francisco Cavalcanti. Tratado de direito privado, $\S 5.498$, p. 1 e ss.

103 Sobre a controvérsia do elemento culpa como integrante da Lex Aquilia original, ou se produto dos glosadores na Idade Média, cf. PEREIRA, Caio Mário da Silva. Responsabilidade civil, p. 5 e HIRONAKA, Giselda Maria Fernandes Novaes. Responsabilidade pressuposta, p. 59 e 77.

${ }^{104}$ INELLAS, Gabriel Cesar Zaccaria de. Da culpa aquiliana. São Paulo: Oliveira Mendes, 1998. p. 8.

105 Constituição Federal. Artigo $3^{\circ}$ : “Constituem objetivos fundamentais da República Federativa do Brasil: I - construir uma sociedade livre, justa e solidária; II - garantir o desenvolvimento nacional; III - erradicar a pobreza e a marginalização e reduzir as desigualdades sociais e regionais; IV - promover o bem de todos, sem preconceitos de origem, raça, sexo, cor, idade e quaisquer outras formas de discriminação."

106 TEPEDINO, Gustavo. Temas de direito civil. 2. ed. Rio de Janeiro: Renovar, 2001. p. 175. 
entre direitos. No mesmo sentido, Giselda Maria Fernandes Novaes Hironaka nos oferece retrato da necessidade de ampliação da ativação contemporânea do instituto da responsabilidade civil afirmando:

"Hoje, os danos são outros e maiores e provêm de situações causadoras outras e novas. Hoje, a previsão de situações danosas ainda não conhecidas se torna difícil, embora a certeza de que existirão. Hoje, a vítima deve ter a possibilidade de ressarcimento garantida em escala de maior segurança" ${ }^{107}$.

Dessa forma, seja na atualidade, seja nos tempos modernos, a tônica da responsabilidade se traduz na função restauradora de uma situação maculada por um fato danoso $^{108}$. Essa função não foi afastada pelas alterações ocorridas, principalmente neste século, muito pelo contrário, prevalece sobre todos os conceitos e doutrinas.

A conduta ilícita, em que pese sua importância, hoje, como um dos fundamentos da responsabilidade civil, senão o mais importante, trouxe peculiaridades ao sistema da responsabilidade civil, deformando-o e retirando-o muitas vezes de sua real função, qual seja a reparação.

Esta situação é muito clara no caso dos acidentes decorrentes do uso de máquina no ambiente de trabalho do século XIX. Por não ter sido o fato danoso um ato de culpa direta do empresário, a vítima não tinha direito, por este sistema, à indenização. Esta exclusividade da culpa no âmbito da reparação civil ocorreu por uma influência econômica, filosófica, moral e até mesmo religiosa, presentes como pano de fundo às questões jurídicas da época ${ }^{109}$.

Eliseu Figueira afirma haver motivos econômicos para a defesa do primado da culpa à época da formação do Código Napoleônico, que posteriormente influenciou as codificações de todo o mundo. Segundo o estudioso:

\footnotetext{
“As verdadeiras razões deste regime jurídico assentam, não nos argumentos ideológicos dos juristas clássicos, mas sim na incapacidade econômica de uma sociedade mercantil, sujeita a crises freqüentes, e na necessidade de proteção da indústria nascente, cujo desenvolvimento não pode ser onerado por uma responsabilidade civil que não seja baseada na culpa"110.
}

107 HIRONAKA, Giselda Maria Fernandes Novaes. Responsabilidade civil e contemporaneidade, p. 209.

108 MONTENEGRO, Antonio Lindenberg C. Responsabilidade civil, p. 6.

109 HIRONAKA, Giselda Maria Fernandes Novaes. Responsabilidade pressuposta, p. 36.

110 FIGUEIRA, Eliseu. Renovação do sistema de direito privado. Lisboa: Editorial Caminho, 1989. p. 201 e ss. Cf. ainda no mesmo sentido: GHERSI, Carlos A. Responsabilidad por actos lícitos. In: BUERES, Alberto José et al (Coord.). Responsabilidad por daños en el tercer milenio. Buenos Aires: Abeledo-Perrot, 1997. p. 474. 
Por conseqüência, a reação do ordenamento jurídico a uma agressão danosa seria apenas a título de punição. Tratar-se-ia de vingança, por meio do aparato estatal, já que este tomou para si o jus punitionis e coibiu a autotutela e a vingança privada ${ }^{111}$. Indenizava-se, desta forma, os prejuízos causados por atitudes culposas. O centro da responsabilidade civil era a culpa do agente.

A responsabilidade civil era vista, nesta concepção, como uma dívida daquele que causou o dano. Suas questões giravam, por ordem decrescente de importância, em torno da ação culposa, da antijuridicidade, da causalidade, da imputabilidade e do dano causado $^{112}$.

Este tipo de visão justifica-se plenamente no âmbito do direito penal, no qual impera soberana a função punitiva do Direito. Todavia, a responsabilização civil atende, por definição e princípio, ao dever indenizatório à vítima. A punição do agente pela via civil é discutível ${ }^{113}$.

Ao direito civil tocam as questões entre os indivíduos, pela proibição da vingança privada, que é historicamente provada como forma de injustiça. Ao direito penal cabe verificar, isento de qualquer sentimento de vingança, se a atitude do indivíduo é merecedora de reprovação.

A reprovação da conduta não pertence ao sistema de responsabilidade civil. Pode ser, isto sim, um efeito acidental da responsabilidade subjetiva por ato ilícito ${ }^{114}$. Nesse sentido, a reparação do dano causado seria uma pena ao agente, tendo, inclusive, um efeito preventivo da conduta no indivíduo e na sociedade. Reafirma-se, porém, que a punição à conduta do indivíduo cabe ao Direito Penal e a reparação do dano sofrido pela vítima é o que toca ao Direito Civil por meio do instituto da responsabilidade civil.

Historicamente, esta visão punitiva predominou, por muito, no sistema da responsabilidade civil, causando sérias injustiças. Em virtude disto, formou-se movimento

Nesse sentido, deve ser interpretada a desconsideração da Súmula n. 229 do STF e a prevalência do inciso XXVII do artigo $7^{\circ}$ da $\mathrm{CF} / 88$.

111 GRINOVER, Ada Pelegrini. Teoria geral do processo, p. 26.

112 LORENZETTI, Ricardo Luis. El sistema de la responsablidad civil, p. 167-168.

113 MARIN, Rubens Leonardo. Dos sentidos da responsabilidade civil no Código Civil de 2002 e sua correlação aos tipos, p. 425 e ss.

114 MARIN, Rubens Leonardo. Dos sentidos da responsabilidade civil no Código Civil de 2002 e sua correlação aos tipos, p. 425 e ss. 
oposto que preconizou, de forma até certo ponto exagerada, ser a vítima o centro da responsabilidade civil ${ }^{115}$.

Para esta corrente extremada, importa muito mais o crédito da vítima do que uma dívida de quem causou dano. Estabeleceu-se, assim, um princípio favor victimae e visou-se a indenização de todo e qualquer dano por um fundo de seguro social comum a todos.

Nesta corrente é comum se preconizar a aplicação da teoria da responsabilidade civil objetiva a toda e qualquer situação, substituindo, de vez por todas, o conceito de culpa. No entanto, por não valorizar também a conduta do agente, por analisar-se apenas a posição da vítima e pela inviabilidade histórica de um fundo de seguridade social comum à sociedade, esta teoria tornou-se extremamente frágil. A posição ideal é exatamente compreender a responsabilidade como a interação dialética entre estas duas visões.

Tomar-se-á a responsabilidade civil como uma relação jurídica neutra, que busca a compensação dos danos sofridos pela vítima, imputando-os a seu agente causador e nada mais $^{116}$.

Silvio Neves Baptista, sobre a função da categoria em estudo leciona: "Não é propriamente sanção, porém uma mera 'compensação' ao titular pelo interesse sacrificado, donde a obrigação de indenizar surge em virtude de lesão do interesse de outrem autorizada por lei" ${ }^{\prime 17}$. Nesta ordem de conceitos, a responsabilidade por conflito de direitos não atende à prevenção da ocorrência dos danos, mas apenas a função da reparação dos danos já ocorridos ${ }^{118}$.

Busca-se, assim, a aplicação do princípio do neminem laedere em seu ponto ótimo, no sentido atribuído por Karl Larenz, de aplicação mais eficiente ${ }^{119}$. A respeito disso, são relevantes as palavras de Carlos Ghersi:

\footnotetext{
115 PEREIRA, Caio Mário da Silva. Responsabilidade civil. Rio de Janeiro: Forense, 1998. p. 22-23.

${ }^{116}$ HIRONAKA, Giselda Maria Fernandes Novaes. Responsabilidade civil e contemporaneidade, p. 210.

${ }^{117}$ BAPTISTA, Silvio Neves. Teoria geral do dano: de acordo com o novo código civil brasileiro. São Paulo: Atlas, 2003. p. 56.

${ }^{118}$ HIRONAKA, Giselda Maria Fernandes Novaes. Responsabilidade pressuposta: evolução de fundamentos e de paradigma da responsabilidade civil na contemporaneidade. In: DELGADO, Mario Luiz; ALVES, Jones Figueiredo (Coord.). Questões controvertidas: responsabilidade civil. São Paulo: Método, 2006. v. 5, p. 199.

119 LARENZ, Karl. Metodologia da ciência do direito, p. 574.
} 


\begin{abstract}
"os autores mais modernos, e em geral a doutrina vitoriosa nos últimos tempos, tem deixado de ver a responsabilidade civil como um castigo para o agente que causa o dano. Seu ponto de vista concentra-se na vítima, antes que no agente causador do dano. Desta forma opinam que toda a teoria da Responsabilidade Civil deve girar sobre aquele que suporta o dano. Os autores mais afinados com este pensamento dizem que não há Responsabilidade Civil, mas sim Reparação de Danos" $" 120$.
\end{abstract}

Nesse sentido, é que deve ser tomada a responsabilidade civil hoje: nem como punição pura ao ofensor nem como crédito daquele que sofreu o prejuízo, mas como compensação ideal destas finalidades ${ }^{121}$, tendo: a) por centro, o dano, como elemento de definição da reparação; b) por fundamento, todo fato que gere a obrigação de indenizar; e c) por princípio, a ordem de conduta expressa pelo neminem laedere ${ }^{122}$.

\title{
2.3.2 O conflito de direitos como fundamento da responsabilidade
}

Enquanto se concebia a responsabilidade apenas como a obrigação devida pelo culpado por dano decorrente de seu ato ilícito, cogitar de uma responsabilidade civil por ato lícito era, no mínimo uma contradictio in terminis, quando não uma antinomia, ou paradoxo interno do ordenamento jurídico.

No entanto, tomando a responsabilidade civil em sua acepção atual, centralizada no dano, a questão mostra-se pacífica.

${ }^{120}$ GHERSI, Carlos Alberto (Coord.). Responsabilidad objetiva: el artículo 1113 y la Ley 24.999. Mendoza: Ediciones Jurídicas Cuyo, 1999. p. 44. No original: "los autores más modernos, y en general la doctrina prevaleciente en los últimos tiempos, han dejado de ver la responsabilidad civil como un castigo para el agente culpable. Su punto de estudio se concentra en la víctima antes que en el agente dañador. De esta forma opinan que toda la teoría de la Responsabilidad Civil debe girar sobre el damnificado. Los autores más afines a este pensamiento hablan, no ya de Responsabilidad Civil, sino de Reparación de Daños".

121 LORENZETTI, Ricardo Luis. El sistema de la responsablidad civil, p. 190.

122 Ainda sobre o primado do dano como centro da responsabilidade civil, Eliseu Figueira (Renovação do sistema de direito privado, p. 205) afirma: "Na sociedade actual, onde a actividade se entrelaça em operações complexas, o problema da responsabilidade nessas áreas não pode constituir na descoberta do verdadeiro autor do facto gerador de danos, mas na atribuição do dever de ressarcimento a um sujeito, não porque a atribuição esteja condicionada por uma liberdade de escolha, mas porque, segundo um critério de valoração dos interesses, a responsabilidade é um conceito de relação entre uma actividade e um sujeito. Portanto, nestas áreas, onde uma rede complexa de factos se entrelaça, como acontece na actividade industrial desenvolvida, o problema da responsabilidade consiste, para se remover as conseqüências de um dano causado a outrem, em estabelecer a relação jurídica entre o facto danoso e um sujeito, o que a não ser possível (sic) remete aquele evento para a categoria de um facto natural. $\mathrm{Na}$ base desta reconstrução do sistema, o fundamento da responsabilidade já não assenta na ilicitude nem na culpa, mas no facto danoso e na relação, segundo um critério jurídico, entre ele e um sujeito responsável". 
Responsabilidade civil é, neste sentido, toda obrigação cujo fundamento, seja ele a culpa ou não, gere a obrigação de indenizar. Miguel Maria de Serpa Lopes ${ }^{123}$ corrobora esta posição em suas lições informando que "responsabilidade significa a obrigação de reparar um prejuízo, seja por decorrer de uma culpa ou de uma outra circunstância legal que a justifique, como a culpa presumida, ou por uma circunstância meramente objetiva". Observa-se que, essencialmente, responsabilidade visa reparação do dano, valorizando-se a função maior do instituto, a reparatória.

Também, a lição de Maria Helena Diniz é no sentido de identificar a responsabilidade como resposta ao dano ao lecionar que "a fonte de responsabilidade civil é o interesse em restabelecer o equilíbrio moral e patrimonial violado pelo dano" ${ }^{\text {124 }}$.

Clóvis Beviláqua, em comentários ao artigo 160 do Código Civil brasileiro de 1916, sobre questões suscitadas pelo Senador João Luís Alves, de serem contraditórios a excludente de ilicitude expressa no citado artigo e a responsabilidade prevista no artigo 1.519 do mesmo Código, corrobora a posição de Justiniano Serpa ${ }^{125}$ quando afirma:

\footnotetext{
"se o eminente senador João Luís Alves nele [no anteprojeto do Código Civil] descobriu contradição, é porque se colocou no ponto de vista da culpa, quando o ponto de partida do Projeto (do Código) é o dano, e emprestou, assim, aos dispositivos, intenção diversa da que eles, naturalmente tinham" (grifos nossos) $)^{126}$.
}

Se o dano é o centro da responsabilidade civil, é inegável que a obrigação indenizatória decorrente de danos sofridos em virtude do conflito entre direitos pertence ao sistema da responsabilidade civil, pois é certo que há dano ${ }^{127}$.

${ }^{123}$ LOPES, Miguel Maria de Serpa. Curso de direito civil, 4. ed., v. V, p. 160.

${ }^{124}$ DINIZ, Maria Helena. Curso de direito civil brasileiro. 20. ed. São Paulo, Saraiva, 2006. v. 7, p. 5.

${ }^{125}$ Beviláqua afirma que "as suas ponderações (de Justiniano Serpa - Presidente da Comissão de elaboração do Código Civil) elucidam, perfeitamente o dispositivo do artigo 160, II do Código Civil de 1916". A mesma interpretação é a de DIAS, José de Aguiar. Da responsabilidade civil. 10. ed. Rio de Janeiro: Forense, 1997. p. 678).

126 Justiniano Serpa, Diário do Congresso, 8 de dezembro de 1915, apud BEVILÁQUA, Clóvis. Código Civil dos Estados Unidos do Brasil comentado. 10. ed. São Paulo: Francisco Alves, 1953. v. 1, p. 347 e ss.

${ }^{127}$ É curiosa a posição de J. M. Carvalho Santos (Código Civil brasileiro interpretado: parte geral. 9. ed. Rio de Janeiro: Freitas Bastos, 1963. v. 3, p. 332), que mantém como fundamento para as hipóteses em tela, o elemento subjetivo. Afirma esse doutrinador "Tais atos lícitos, isto é, praticados de acordo com o direito, criam, não obstante, para o agente a obrigação de indenizar, porque neles interveio a vontade com o fito de assegurar um bem a quem o pratica ou a terceiro. Não é a conseqüência danosa que obriga à reparação, como têm dito escritores de tomo: é também a concorrência daquele elemento subjetivo, cuja presença faz com que o ato se opere de modo a não poder atribuir-se ao caso fortuito ou à força maior, que se identificam com a ação de causas que estão fora do alcance da vontade humana, isto é, tudo o que se não pode prever, ou que, previsto, não se pode evitar. Em suma, o sujeito que se vê em estado de necessidade, pode sujeitar-se ao mal evitável. A mesma coisa é possível no caso de agressão injusta: a vítima pode optar por sofrer a ofensa, em vez de repeli- 
Se com exercício regular de um direito causa-se dano, e este ato é tipificado pelo legislador como gerador de indenização, independentemente de sua licitude, esta obrigação reparatória inserir-se-á no sistema da responsabilidade civil, responsabilizando seu autor e provendo à vítima a sua justa reparação.

Ressalte-se ainda que, em se tratando de responsabilidade civil decorrente do conflito de direitos, o efeito punitivo da reparação não deve existir, pois a conduta do agente é secundum ius e, portanto, não é merecedora de repúdio e punição. Por conseqüência, a função preventiva também fica prejudicada ${ }^{128}$.

Todavia, a função reparatória, essência maior da responsabilidade civil, está presente em toda sua força neste instituto.

Alguns autores preferem sistematizar as hipóteses desta categoria como casos de enriquecimento sem causa, ou ainda enriquecimento ilícito. É o caso de G. P. Chironi que ao tratar do estado de necessidade afirma que é devida a indenização, mesmo sem culpa, por tratar-se de enriquecimento ilícito, pois se enriquecer com dano alheio é uma responsabilidade por ofensa objetiva ${ }^{129}$. Permissa venia, não se pode concordar com tal opinião.

Em primeiro lugar, não há enriquecimento de qualquer dos sujeitos na relação obrigacional da responsabilidade. Não há vantagem patrimonial $^{130}$ àquele que causa $o$ dano, e se há, foi determinada por lei. Em segundo lugar, a causa para a alteração patrimonial dos sujeitos é, faticamente, um ato lícito e, juridicamente, a lei. Assim, não se trata de enriquecimento, mas a imposição de um direito mais importante e necessário naquele momento, do qual, no mais das vezes, justifica-se por sua necessidade e importância. Assim, nem sempre há o enriquecimento, e quando existe é lícito e plenamente justificado, impossibilitando classificar esta categoria como hipóteses de enriquecimento ilícito ou sem causa. Por fim, deve ser lembrado o argumento de Alvino

la, matando ou ferindo". Assim, a existência da "opção" entre causar o dano ou sofrê-lo é que justificaria a reparação.

${ }^{128}$ MARIN, Rubens Leonardo. Dos sentidos da responsabilidade civil no Código Civil de 2002 e sua correlação aos tipos, p. 425.

${ }_{129}$ CHIRONI, G. P. La colpa nel diritto civile odierno. 2. ed. Torino: Fratelli Bocca, 1906. v. II, p. 515.

${ }^{130}$ Sobre o conceito de enriquecimento sem causa cf. GOMES, Orlando. Obrigações. 16. ed. Rio de Janeiro: Forense, 2006. § 182, p. 294. 
Lima, segundo o qual esta teoria não satisfaz, pois não abrange os casos de atos de necessidade altruístas, isto é, atos em estado de necessidade em favor de terceiro ${ }^{131}$.

Apenas como exemplo, cita-se o caso do motorista que, para desviar de pedestre, atinge carro alheio, tornando-se, desta forma, devedor de reparação. Pergunta-se: qual o enriquecimento deste motorista?

Mais correto seria afirmar, no mesmo sentido de Alberto Trabucchi ${ }^{132}$, Alvino Lima $^{133}$, Adriano de Cupis ${ }^{134}$ entre outros, ser esta indenização a compensação de um dano sofrido pelo exercício de um interesse da coletividade ao qual, por não ser justo ao prejudicado suportar sozinho o benefício de todos, a própria coletividade lhe prevê uma indenização compensatória por meio do Estado.

Também, neste trabalho, não se concorda, por entender ser parcialmente correta, com a posição de Giorgio Giorgi ${ }^{135}$, e aceita por José de Aguiar Dias, que sustenta ser este tipo de reparação baseada na eqüidade, na solidariedade ou na assistência social. Concorda-se que estes são os princípios que fundam a responsabilidade por conflito de direitos, mas, na verdade, são os que devem reger todo o ordenamento jurídico. A eqüidade e a solidariedade permeiam o Direito; adotá-las como fundamento exclusivo e imediato de um tipo específico de reparação pouco esclarece sobre a categoria.

Não se concorda com a posição de Gustavo Ordoqui Castilla ${ }^{136}$, que prefere enquadrar o instituto em questão como mera obrigação de compensar danos causados por condutas lícitas, negando a integração destas hipóteses ao sistema da responsabilidade civil.

Afirma este doutrinador uruguaio que em virtude de ter-se utilizado por muito tempo, o termo responsabilidade civil para denominar apenas os casos de responsabilidade subjetiva baseada na culpa, alterar-se isso, hoje, para contemplar todas as situações de dano reparável, traria confusão e perderia a utilidade do termo tornando-o um rótulo obscuro e confuso $^{137}$. Deve-se considerar a prudência do doutrinador em evitar confusões

\footnotetext{
131 LIMA, Alvino. Culpa e risco, p. 185.

132 TRABUCCHI, Alberto. Instituzione de diritto civile. 5. ed. Pádua: Cedam, 1950. § 93, p. 189.

133 LIMA, Alvino. Culpa e risco, p. 303.

134 DE CUPIS, Adriano. Il danno, p. 25.

135 GIORGI, Giorgio. Teoria delle obligazioni nel diritto moderno italiano. 7. ed. Firenzi: Fratelli Cannelli, 1909. v. 5, p. 277. No mesmo sentido, ver DIAS, José de Aguiar. Da responsabilidade civil, p. 677.

136 Obligacion de compensar daños causados por conductas lícitas, p. 12.

137 CASTILLA, Gustavo Ordoqui. Obligación de compensar daños causados por conductas lícitas, p. 12.
} 
terminológicas, mas não se pode aceitar o "engessamento" da responsabilidade civil aos casos de responsabilidade subjetiva.

A própria origem do termo não impede a utilização renovada. Giselda Hironaka ${ }^{138}$, nos conduz, com maestria, sobre este ponto, informando ser o conceito de responsabilidade civil construído, no ambiente jurídico civilista, apenas no século XIX, com o objetivo de explicar os fundamentos das obrigações de $\operatorname{reparar}^{139}$.

Todavia, em sua forma mais arcaica, o termo responsabilidade deriva etimologica e filologicamente dos verbos latinos spondere, spondeo, com sentido de "se tomar garantia em juízo, dar sua caução pessoal a alguém"140. O termo respondere, de mesma raiz etimológica de responsabilidade, mantém o sentido de garantia retribuída ${ }^{141}$.

Confirma-se a inexistência da idéia de culpa na formação de tais termos. Como leciona a citada autora, "spondere é comprometer, prometer, engajar, enlaçar. Respondere, quando muito, é a devolução, no mesmo ato, de uma promessa ou de uma dádiva equivalente" ${ }^{142}$, ou seja, uma reação, uma resposta.

Como bem sumarizado na obra de Washington de Barros, "a maior parte da doutrina nacional e estrangeira explica a responsabilidade civil por meio de seu resultado ou conseqüência: a reparação de danos" e continua o autor "a responsabilidade civil visa ao restabelecimento da ordem ou equilíbrio pessoa e social, por meio da reparação dos danos morais e materiais oriundos de ação lesiva a interesse alheio, único meio de cumprir-se a própria finalidade do direito, que é viabilizar a vida em sociedade, dentro do conhecido ditame de neminum laedere"

No mesmo sentido, a singela contribuição de De Plácido e Silva ${ }^{144}$, tratando do vocábulo RESPONSABILIDADE, leciona:

"Forma-se o vocábulo de responsável, de responder, do latim respondere, tomado na significação de responsabilizar-se, vir garantindo, assegurar, assumir o pagamento do que se obrigou ou do ato que praticou. (...) Onde quer, portanto,

\footnotetext{
${ }^{138}$ HIRONAKA, Giselda Maria Fernandes Novaes. Responsabilidade pressuposta, p. 73 e p. 76 e ss

139 HIRONAKA, Giselda Maria Fernandes Novaes. Responsabilidade pressuposta, p. 73.

140 HIRONAKA, Giselda Maria Fernandes Novaes. Responsabilidade pressuposta, p. 83.

141 HIRONAKA, Giselda Maria Fernandes Novaes. Responsabilidade pressuposta, p. 84.

142 HIRONAKA, Giselda Maria Fernandes Novaes. Responsabilidade pressuposta, p. 85.

${ }^{143}$ MONTEIRO, Washington de Barros. Curso de direito civil, p. 501 e 502.

144 SILVA, De Plácido e. Vocabulário Jurídico, 20. ed., Rio de Janeiro: Forense, 2002. p. 713
} 
que haja a obrigação de fazer, dar, ou não fazer alguma coisa, de ressarcir danos, de suportar sanções legais ou penalidades, há a responsabilidade, (...)”145.

Dessa forma, o responder não implica necessariamente uma conduta culposa, mas, sim, "a obrigação de satisfazer a prestação ou de cumprir o fato atribuído ou imputado à pessoa por determinação legal"146.

Portanto, apenas por costume se admitiria a reserva do vocábulo responsabilidade somente aos casos de responsabilidade por culpa. Costume que nada possui de científico e muito impróprio, diante do qual não nos posicionamos. A evolução de um instituto não gera sua descaracterização, mas, sim, evolução, portanto admitimos a utilização do termo responsabilidade civil para todos os casos, como propostos por grande parte da doutrina, em que existe o dano reparável.

Vários são os doutrinadores que corroboram a posição de que a responsabilidade civil implica a reparação de um dano sofrido, independentemente da natureza da conduta que o produz. É esta a posição de Maria Helena Diniz quando aponta que:

"A responsabilidade civil é a aplicação de medidas que obriguem uma pessoa a
reparar o dano moral ou patrimonial causado a terceiros, em razão de ato por ele
mesmo praticado, por pessoa por quem ela responde, por alguma coisa a ela
pertencente ou de simples imposição legal""

De acordo com Miguel Maria de Serpa Lopes “a responsabilidade é a obrigação de reparar um dano, seja por decorrer de uma culpa ou de uma outra circunstância legal que a justifique, como a culpa presumida, ou por uma circunstância meramente objetiva"148.

Caio Mário da Silva Pereira ressalta a independência das causas para determinação do instituto da responsabilidade civil quando leciona:

\footnotetext{
"A responsabilidade civil consiste na efetivação da reparabilidade abstrata do dano em relação a um sujeito passivo da relação jurídica que se forma. Reparação e sujeito passivo compõem o binômio da responsabilidade civil, que então se enuncia como o princípio que subordina a reparação à sua incidência na pessoa causadora do dano. Não importa se o fundamento é a culpa, ou se é independente desta. Em qualquer circunstância, onde houver a subordinação de um sujeito passivo à determinação de um dever de ressarcimento, aí estará a responsabilidade civil"149.
}

145 SILVA, De Plácido e. Vocabulário jurídico, p. 713.

146 SILVA, De Plácido e. Vocabulário jurídico, p. 713.

147 DINIZ, Maria Helena. Curso de direito civil brasileiro, p. 40.

148 LOPES, Miguel Maria de Serpa. Curso de direito civil, 4. ed. v. V, p. 160.

149 PEREIRA, Caio Mário da Silva. Responsabilidade civil, p. 11. 
Paulo Nalin nos recorda a importância de que a responsabilidade civil nada mais transparece do que os valores históricos de uma sociedade:

\begin{abstract}
"A riqueza e a extensão dos elementos que compõe a responsabilidade civil tornam difíceis a tarefa de conceituá-la, não sendo de todo imprudente, ao invés de elaborar um conceito, relacioná-la à sua finalidade primordial: sanção pelo desrespeito a valores socialmente reconhecidos e amparados pelas normas próprias, protetivas de direitos relativos ou absolutos. $\mathrm{O}$ destaque pelos seus elementos componentes também é interessante para afins de definição,"150.
\end{abstract}

No mesmo sentido Pablo Stolze e Rodolfo Pamplona afirmam: “(...) a responsabilidade civil deriva da agressão a um interesse eminentemente particular, sujeitando, assim, o infrator, ao pagamento de uma compensação pecuniária à vítima, caso não possa repor in natura o estado anterior de coisas"151.

Os sentidos amplos e estritos da responsabilidade civil são afirmados por Francisco Amaral que expõe:

“A expressão 'responsabilidade civil’ pode compreender-se em sentido amplo ou
em sentido estrito. Em sentido amplo, tanto significa a situação jurídica em que
alguém se encontra de ter de indenizar outrem quanto própria obrigação
decorrente dessa situação, ou, ainda, o instituto jurídico formado pelo conjunto
de normas e princípios que disciplinam o nascimento, conteúdo e cumprimento
de tal obrigação. Em sentido estrito, designa o específico dever de indenizar
nascido de fato lesivo imputável a determinada pessoa. É civil porque a relação
se estabelece entre particulares, deixando-se ao direito administrativo o problema
da responsabilidade do Estado, pelos danos resultantes do funcionamento dos
serviços públicos”152.

Todavia, não se coaduna com a posição, que neste trabalho se expõe, da lição de Sergio Cavalieri Filho, que conceitua responsabilidade civil de forma mais estrita como “dever jurídico sucessivo que surge para recompor o dano decorrente da violação de um dever jurídico originário"153. Para o citado autor, "alguém tem de reparar o prejuízo decorrente da violação de um outro dever jurídico" ${ }^{154}$. Mantém a necessidade de, no plano da responsabilidade civil, a prévia existência de um dever jurídico a ser cumprido.

Em que pese a posição do eminente doutrinador, tal sistematização não oferece subsídios para esclarecer a responsabilidade civil nos casos que, denomina-se, por conflitos

\footnotetext{
${ }^{150}$ NALIN, Paulo Roberto Ribeiro. Responsabilidade civil: descumprimento do contrato e dano extrapatrimonial. Curitiba: Juruá, 1996. p. 45.

151 GAGLIANO, Pablo Stolze; PAMPLONA FILHO, Rodolfo. Novo curso de direito civil: contém análise comparativa dos códigos de 1916 e 2002. São Paulo: Saraiva, 2004. v. III, p. 9.

152 AMARAL, Francisco. Direito civil: introdução. 5. ed., rev., atual. e aum. Rio de Janeiro: Renovar, 2003. p. 558.

153 CAVAlIERI FILHO, Sergio. Programa de Responsabilidade Civil, p. 24.

154 CAVALIERI FILHO, Sergio. Programa de Responsabilidade Civil, p. 24.
} 
de direitos, limitando-se a denominar tais hipóteses como simplesmente, "obrigação de indenizar",155 e 156 .

Por todo exposto, reafirmamos nosso entendimento no mesmo sentido de Carlos Alberto Bittar ${ }^{157}$, Miguel Maria de Serpa Lopes ${ }^{158}$ e Maria Helena Diniz ${ }^{159}$, identificando a responsabilidade civil à restauração de equilíbrio afetada pelo dano sofrido, tendo o dano como centro do sistema da responsabilidade civil, e com Karl Larenz ${ }^{160}$, Carlos Roberto Gonçalves ${ }^{161}$, entre vários outros doutrinadores de escol, que tratam os casos desta categoria como caso autônomo de fundamento da responsabilidade civil.

Desta forma, são três as hipóteses que fundamentam a responsabilidade civil: a primeira, a conduta ilícita na qual o agente ofende direito ou bem alheio contrariando o ordenamento jurídico; a segunda, a atividade que possui um risco intrínseco de dano e, apesar de admitida pelo ordenamento jurídico, todo o dano que dela provier deverá ser indenizado; e, por fim, a terceira hipótese é aquela na qual há um conflito entre dois direitos, em que, para sua solução, um deles, o menos valioso do ponto de vista ético e humano, cessará, definitiva ou transitoriamente, sobrepondo-o um mais importante.

Em apoio à tese, Inocêncio Galvão Telles ${ }^{162}$, de forma sucinta, assim se posiciona: "Temos assim, em resumo, três categorias de responsabilidade extraobrigacional: a) responsabilidade por acto ilícito; b) responsabilidade por acto lícito; c) responsabilidade pelo risco".

De forma mais detalhada, Alvino Lima ${ }^{163}$ elaborou quadro sistemático da responsabilidade extracontratual, no qual se vê como os casos da categoria em questão se

${ }^{155}$ CAVAlIERI FILHO, Sergio. Programa de Responsabilidade Civil, p. 28.

156 Acompanha a posição de Sergio Cavalieri Filho, sem adentrar na questão, Pablo Stolze e Rodolfo Pamplona quando, ao versar sobre a responsabilidade civil prevista nos arts. 1.285 e 1.313 informam que "em situações excepcionais, os atos lícitos poderão impor a obrigação de indenizar (GAGLIANO, Pablo Stolze; PAMPLONA FILHO, Rodolfo. Novo curso de direito civil. 7. ed. São Paulo: Saraiva, 2006. v. I, p. 505). Na obra específica sobre responsabilidade civil os autores apresentam, para os casos de estado de necessidade que "diz-se comumente, na hipótese, haver uma "colisão de interesses jurídicos tutelados" (GAGLIANO, Pablo Stolze; PAMPLONA FILHO, Rodolfo. Novo curso de direito civil, v. III, p. 9 e p. 112). Ora o que é isso senão a definição de direito subjetivo?

157 BITTAR, Carlos Alberto. Responsabilidade civil: teoria e prática. 3. ed. Rio de Janeiro: Forense Universitária, 1999. p. 2.

${ }^{158}$ LOPES, Miguel Maria de Serpa. Curso de direito civil. 4. ed. v. V, p. 160.

159 DINIZ, Maria Helena. Curso de direito civil brasileiro, p. 5.

160 Derecho de obligaciones, § 72, p. 690.

161 Responsabilidade civil, p. 6.

162 Direito das obrigações, p. 208 e ss.

163 Culpa e risco, p. 319. 
enquadram perfeitamente como hipóteses de responsabilidade civil. Em destaque, por grifo nosso, a responsabilidade ex lege decorrente do conflito entre direitos. As referências são de artigos do Código Civil de 1916.

Figura 2.1 Quadro sistemático da responsabilidade extracontratual

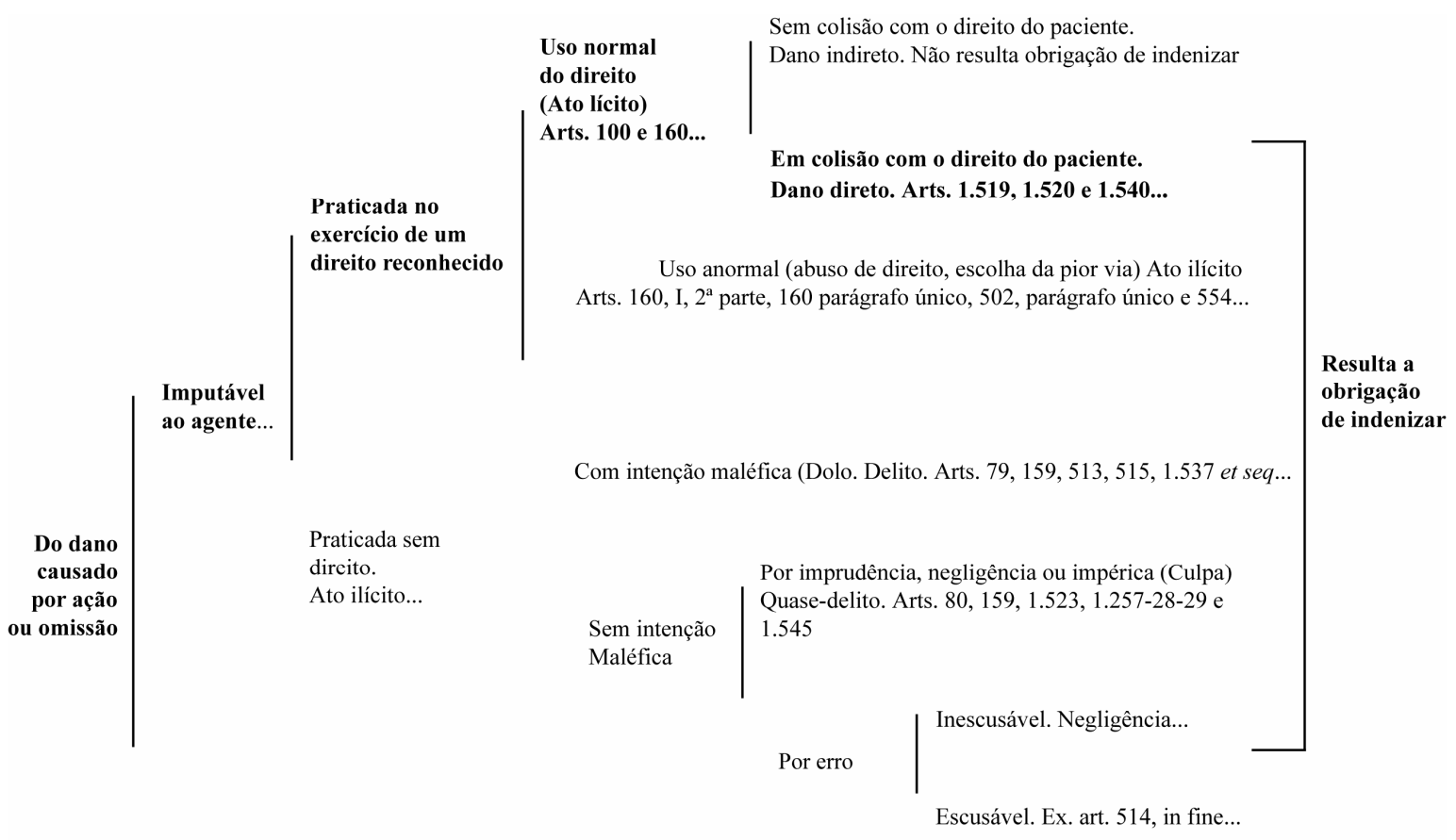

Não imputável (Enriquecimento indébito. Ato de pessoa incapaz. Ato de terceiro.

Reposição do incapaz ao responsável direto). Código Civil, arts. 96, 1.521 e 1.545; Digesto português I, 472.

Fonte: LIMA, Alvino. Culpa e risco, p. 319.

\subsubsection{Natureza extracontratual}

Concebe-se, a priori, a reparação decorrente do conflito de direitos como extracontratual. Todas as suas hipóteses estão descritas em texto legal e não importam em vínculo preexistente entre seus atores.

Carlos Roberto Gonçalves, sem argumentar a respeito, denomina o capítulo em que trata desta categoria como "Responsabilidade extracontratual por atos ilícitos e lícitos (fundada no risco e decorrente dos fatos permitidos por lei)"164 (grifo nosso).

${ }^{164}$ GONÇALVES, Carlos Roberto. Responsabilidade civil, p. 29. 
A classificação teria, desta forma, interesse meramente acadêmico, visto que pouco esclareceria sobre o assunto. No entanto, na análise desta possibilidade, duas situações conexas tornaram-se dignas de nota e estudos e nos levaram a algumas conclusões.

A primeira surge da análise da Lei n. 9.610 de 19/02/1998, sobre direitos autorais. Ao autor de obra intelectual é concedido, entre outros, o direito de modificar sua obra ou de retirá-la de circulação, porém, deve ressalvar os direitos de, por exemplo, seu editor que investiu e produziu exemplares que não poderão ser vendidos por determinação do autor. Surge daí o conflito. De um lado, o autor plenamente garantido em exigir que sua obra não circule; de outro, o editor que se vê à mercê da vontade unilateral de seu contratado. Deste conflito, por previsão expressa no artigo $24 \S 3^{\circ}$ desta mesma lei ${ }^{165}$, prevalece, por sua importância, o direito moral do autor sobre o patrimonial do editor. Entretanto, deverá o autor, causador do dano, ainda que tenha agido em exercício regular de direito seu, indenizar seu editor ${ }^{166}$.

Numa situação com tais características, poder-se-ia crer na existência de responsabilidade em conflito de direitos na modalidade contratual, porém, o caso tende a ser melhor explicado, talvez, por mero descumprimento contratual. Assim, não cumprindo o autor a obrigação assumida contratualmente, responde pelo princípio genérico do artigo 389 do Código Civil, apenas reproduzido em forma específica o artigo $24 \S 3^{\circ}$ da citada lei, pelas perdas e danos de seu editor. Este seria o correto fundamento da reparação na situação proposta.

A segunda situação, muito mais complexa, que pode gerar confusão no âmbito contratual refere-se à questão do fundamento da reparação em perdas e danos conseqüente a todo rompimento contratual, ou, a fortiori, em obrigação de fazer infungível. Esta tese apenas se expõe a título de especulação, por serem suas conclusões, aparentemente necessárias, muito curiosas.

\footnotetext{
165 Art. 24. "São direitos morais do autor: (...) V - o de modificar a obra antes ou depois de utilizada; VI - o de retirar de circulação a obra ou de suspender qualquer forma de utilização já autorizada, quando a circulação ou utilização implicarem afronta à sua reputação e imagem; VII - o de ter acesso a exemplar único e raro da obra, quando se encontre legitimamente em poder de outrem para o fim de, por meio de processo fotográfico ou assemelhado, ou audiovisual, preservar sua memória, de forma que cause o menor inconveniente possível a seu detentor, que, em todo caso, será indenizado de qualquer dano ou prejuízo que lhe seja causado. (...) $\S 3^{\circ} \operatorname{Nos}$ casos dos incisos V e VI, ressalvam-se as prévias indenizações a terceiros, quando couberem".

166 Nesse sentido, cf. TUCCI, Giuseppe. La risarcibilita'del danno da atto lecito nel diritto civile. Rivista di Diritto Civile, Padova: Cedam, ano XIII, 1967. p. 235 e ss.
} 
A responsabilidade por conflito de direitos ocorreria, neste caso, por decorrência do princípio constitucional de que "ninguém será obrigado a fazer ou deixar de fazer alguma coisa senão em virtude de lei" ${ }^{\text {167 }}$. Ora, se apenas a lei obriga compulsoriamente, e o contrato está excluído desta hipótese, logo, o descumprimento contratual seria conforme o ordenamento jurídico (lícito) além de ser um direito garantido constitucionalmente, que se contrapõe ao direito da parte contrária, garantido apenas contratualmente.

Do conflito existente entre o direito constitucional de não ser forçado a cumprir versus o direito contratual de ter sua prestação adimplida, em tese, prevaleceria o direito constitucional de se abster da atividade contratada, porém, com a necessária reparação de danos conseqüentes a esta conduta ${ }^{168}$.

Com efeito, e prudentemente, poder-se-ia afirmar que a obrigação decorrente do contrato, ou seja, o debitum, Schuld, ou dever de prestação, por ser obrigação de fazer na esfera pessoal, não pode ser exigida, porém a obrigação decorrente de seu descumprimento prevista legalmente no ordenamento jurídico brasileiro, no artigo 389 do Código Civil, ou seja, a obligatio, Haftung, que é o dever de sujeição do devedor, apenas na ordem patrimonial $^{169}$, a esta última não se pode eximir. Estaria, portanto, plenamente justificada reparação decorrentes de inexecução voluntária.

É mais clara esta situação chegando a atrair parte da doutrina, quando se trata de rompimento de esponsais ${ }^{170}$, em que se entende ser lícito ao parceiro romper o compromisso (ou contrato), mas é devido ao outro reparação de seus gastos e dor moral, tudo em virtude de um ato lícito, pois não é nem pode ser imposto a alguém a obrigação de se casar contra a sua vontade apenas em virtude de uma promessa. No entanto, os gastos que se deu causa em virtude desta, devem ser indenizados.Como solução, em sentido oposto, como hipótese de responsabilidade decorrente do conflito de direito, afirma-se que o lícito não se confunde com o meramente legal, e, apesar do silogismo ${ }^{171}$ exposto ser

\footnotetext{
${ }^{167}$ Constituição Federal artigo $5^{\circ}$, inciso II.

168 Conforme informa o artigo 389 do Código Civil.

169 MONTEIRO, Adriano Malta. Schuld e Haftung: implicações filosóficas (obra ainda não publicada, cortesia do autor).

${ }^{170}$ Cf. TRABUCCHI, Alberto. Instituzione de diritto civile, § 93, p. 185; BAPTISTA, Silvio Neves. Ensaio sobre a teoria do fato danoso, p. 57; DE CUPIS, Adriano. Il danno, p. 25; GONÇALVES, Carlos Roberto. Responsabilidade civil, p. 61; TUCCI, Giuseppe. La risarcibilita'del danno da atto lecito nel diritto civile, p. 235, entre outros.

171 Toda conduta obrigatória é determinada por lei, nenhuma lei é contrato, logo nenhuma conduta obrigatória é determinada por contrato. Ou sinteticamente: só a lei obriga, o contrato não é lei, logo o contrato não obriga.
} 
verdadeiro, o ordenamento jurídico, base de determinação da licitude ou não, do ato, não permite o descumprimento do contrato, atitude que é reprovada e, portanto, ilícita.

Além disto, pode-se argumentar que é a lei, mesmo indiretamente, que embasa o contrato, concedendo espaço para manifestação da autonomia privada. A afronta ao contrato seria também uma afronta à lei e, portanto, ilícita.

Mesmo com estes esclarecimentos, talvez pudéssemos pensar nestas hipóteses como de surgimento de obrigação de indenizar decorrente do conflito de direitos no âmbito contratual. Os limites deste trabalho, entretanto, nos impedem de avançar os estudos neste sentido. No entanto, estas são situações, no mínimo, curiosas que merecerão o cuidado devido em momento posterior.

\subsubsection{Natureza objetiva}

Inclui-se a responsabilidade civil por conflito de direitos com espécie de responsabilidade objetiva, definida esta, de modo negativo e binário, como toda responsabilidade que prescinde do elemento culpa (lato sensu) do agente para ocorrer ${ }^{172}$. Não se pesquisa na conduta daquele que causa o dano, em exercício regular de direito, se agiu com dolo ou negligência, imprudência ou imperícia. Analisar-se-á o fato, o dano e a situação em que ocorreu a lesão.

É o que na lição de Pontes de Miranda se denomina ato-fato jurídico indenizativo. Marcos Bernardes de Melo, sobre a posição desse autor, esclarece serem estas situações "em que de um ato humano não contrário a direito (= lícito), decorre prejuízo a terceiro, com dever de indenizar" ${ }^{\prime 17}$. Nos dizeres do próprio Pontes de Miranda, o ato-fato jurídico é aquele em que "o fato para existir necessita, essencialmente, de um ato humano, mas, a

172 PEREIRA, Caio Mário da Silva. Responsabilidade civil, p. 261 ss.

173 MELO, Marcos Bernardes de. Teoria do fato jurídico: plano da existência. 12. ed. São Paulo: Saraiva, 2003. $\S 35$, p. 131. 
norma jurídica abstrai desse ato qualquer elemento volitivo como relevante"174. Assim, desconsidera-se a vontade para se dar mais atenção ao fato estabelecido ${ }^{175}$.

Esta ordem de conceitos está de acordo com o princípio da responsabilidade objetiva, da qual são espécies a responsabilidade pelo risco e a responsabilidade pelo conflito de direitos, pois, em que pese se tratar de ato humano, qualquer elemento da vontade é prescindido ressaltando-se a conseqüência do ato. Dá-se mais importância ao efeito, no caso o dano, do que o ato que o praticou, se lícito ou ilícito. Não se faz exame da culpa do agente, mas, sim, a análise do dano e previsão legal de sua compensação. Destarte, nos dizeres do próprio Pontes de Miranda "A responsabilidade pelo ato sem culpa abstrai de todo elemento de capacidade, à semelhança do que ocorre com os fatos ilícitos"176.

A responsabilidade pelo conflito de direitos pode ser classificada também como responsabilidade objetiva, pois que prevalece o elemento objetivo, dano, sobre o subjetivo, culpa, como fundamento de sua reparação, à semelhança do que ocorre com a responsabilidade pelo risco. A responsabilidade por risco e a pelo conflito de direitos têm ainda como característica o fato de decorrerem de uma atividade lícita.

$\mathrm{Na}$ responsabilidade pelo risco a atividade é lícita já que, mesmo perigosa, é permitida pelo legislador, com a ressalva de que, na ocorrência de qualquer dano, será indenizado objetivamente.

${ }_{174}$ MELO, Marcos Bernardes de. Teoria do fato jurídico, § 34, p. 106.

175 Pontes de Miranda em seu Tratado de Direito Privado, $\S 209$, p. 421 esclarece: "os atos-fatos jurídicos são os fatos jurídicos que escapam às classes dos negócios jurídicos, dos atos jurídicos stricto sensu, dos atos ilícitos, inclusive atos de infração culposa das obrigações, da posição de réu e de exceptuado (ilicitude infringente contratual), das caducidades por culpa, e dos fatos jurídicos stricto sensu. Abrangem os chamados atos reais, a responsabilidade sem culpa, seja contratual, seja extracontratual, e as caducidades sem culpa (exceto o perdão). Ainda quando, no suporte fáctico, de que emanam, haja ato humano, com vontade ou culpa, êsses atos são tratados como ato-fato (...)" e continua "Ato humano é o fato produzido pelo homem; às vezes, não sempre, pela vontade do homem. Se o direito entende que é relevante essa relação entre o fato, a vontade e o homem, que em verdade é dupla (fato, vontade-homem), o ato humano é ato jurídico, lícito ou ilícito, e não ato-fato, nem fato jurídico stricto sensu. Se mais rente ao determinismo da natureza, o ato é recebido como fato do homem (relação "fato, homem"), com o que se elide o último têrmo da primeira relação e o primeiro da segunda, pondo-se entre parêntese o quid psíquico, o ato, fato (dependente da vontade) do homem, entra no mundo jurídico como ato-fato jurídico. Não se desce à consciência, ao arbítrio de se ter buscado causa a fato da vida e do mundo (definição de vontade consciente); satisfaz-se o direito com a determinação exterior. Actus vem de ago, agere. Há movimento próprio, com objetivo, ou mesmo fim (...) No factum, há apenas, o 'feito'; donde pode-se distinguir do fato a vontade (distinguire voluntatem a facto). Se esvaziamos os atos humanos de vontade (= se dela abstraímos = se a pomos entre parênteses), se não a levamos em conta para a juridicização, $o$ actus é factum, e como tal é que entra no mundo jurídico".

176 PONTES DE MIRANDA, Francisco Cavalcanti. Tratado de direito privado, p. 248. 
Já no caso da responsabilidade por conflito de direitos, a atividade do agente é lícita porque mesmo causando dano, visa a proteção de um bem maior que o danificado, expressamente determinada pelo legislador.

Tal similitude é mantida também na classificação proposta por Álvaro Villaça Azevedo, ao classificar a responsabilidade objetiva em espécies pura e impura. Nesta concepção, tanto a responsabilidade por riscos como por conflito de direitos tratar-se-iam de hipóteses de responsabilidade objetiva pura, uma vez que implicam



O fundamento da responsabilidade civil objetiva é expresso pelo princípio do $u b i$ commoda, ibi incommoda ${ }^{178}$, ou nos dizeres de Alberto Trabucchi "responsabilidade objetiva, a qual baseia-se sobre um princípio genérico de eqüidade. Quem tem vantagem com algo, responde por suas desvantagens: ubi commoda, ibi incommoda"179.

Por fim, como última característica da responsabilidade objetiva, e conseqüentemente de suas espécies, tem a sua prova simplificada em relação à da responsabilidade subjetiva. Para aquela, basta a prova do dano e do nexo de causalidade de conduta do agente, não se buscando muitas digressões. Provado o tipo e imputada a conduta, está provada a necessidade de reparação obrigatória.

Estas facilidades no onus probandi são conseqüências de que este tipo de responsabilidade decorre de casos expressos pela legislação. Assim, com a ocorrência dos elementos requeridos por lei, com pouca extensão, porém grande compreensão, pouco resta a ser provado. Apenas prova-se que a hipótese abstrata da lei ocorreu faticamente e que a conduta do agente guarda nexo de causalidade com o evento.

Assim, por definição, e pelas similitudes entre as espécies, ter-se-á responsabilidade civil objetiva como gênero do qual a responsabilidade por risco e a responsabilidade decorrente do conflito entre direitos são suas espécies.

177 AZEVEDO, Álvaro Villaça. Proposta de classificação da responsabilidade objetiva: pura e impura, Revista dos Tribunais, São Paulo: RT, v. 698, dez. 1993, p. 8.

${ }_{178}$ Na mesma ordem de idéias é o princípio romano: ubi emolumentum, ibi onus.

179 TRABUCCHI, Alberto. Instituzione de diritto civile, § 93, p. 189. No original: "responsabilità oggettiva, la quale si basa sopra un principio di generica equità. Chi trae vantaggio da una cosa risponde anche degli svantaggi: ubi commoda, ibi incommoda". 
Cabe ressaltar que as espécies, em que pesem as semelhanças presentes no gênero comum, não se confundem, possuindo, cada qual, a sua differentia especifica. É o que interessa estudar.

\subsubsection{Autônoma}

A responsabilidade civil ex lege decorrente do conflito entre direitos é um fundamento autônomo da responsabilidade civil, em mesmo nível sistemático da reparação por atos ilícitos e da responsabilidade por riscos, embora não se confunda com estas.

Não se trata de mero apêndice do sistema da responsabilidade civil, uma pequena exceção à regra geral da culpa, decorrente de algum devaneio do legislador. Também não se entende ser uma situação de risco especial, por exemplo, um risco necessário. Cuida-se, isto sim, de uma situação típica, com regras e sistemática própria que confirma a idéia de justiça no campo civil ${ }^{180}$, atende ao dever geral de solidariedade e valoriza a posição do prejudicado pela compensação do dano por ele sofrido. Tecem-se, assim, comentários visando fortalecer esta posição de autonomia.

No tocante ao fundamento da conduta ilícito-culposa não há que se cogitar de qualquer confusão. Se a culpa for tratada no mesmo sentido de Alvino Lima, como "um erro de conduta, moralmente imputável ao agente e que não seria cometido por uma pessoa avisada" ${ }^{181}$, é evidente que ela não está no ato daquele que causa dano em exercício regular de direito.

Tome-se, por exemplo, o caso de quem age em estado de necessidade e causa dano a terceiro. Não há erro de conduta, não há culpa, não há ilicitude (artigo 188 do Código Civil), ao contrário, é probo e diligente quem assim se conduz, protegendo com seu ato um valor maior. Entretanto, esse agente deve reparação por não ser justo à vítima suportar sua opção (artigo 929 do Código Civil). Ressalte-se, com o perdão da repetição didática, que não há erro de conduta.

\footnotetext{
${ }^{180}$ CASTILLA, Gustavo Ordoqui. Obligación de compensar daños causados por conductas lícitas, p. 12.

181 LIMA, Alvino. Culpa e risco, p. 69.
} 
Não podemos aceitar a posição de que a responsabilidade decorrente do conflito de direitos seja apenas um apêndice anômalo da responsabilidade civil ${ }^{182}$, considerando-a como mera exceção ao princípio da culpa ${ }^{183}$. Entendemos, como informa Gustavo Ordoqui Castilla que este tipo de responsabilidade

\begin{abstract}
"tem uma estrutura peculiar, já que seu pressuposto de existência prescinde de uma conduta ilícito-culposa; e uma função específica, pois a soma de dinheiro devida não é por motivos sancionatórios-ressarcitórios, mas sim compensatórios, respondendo a um critério que pretende resolver os conflitos de interesse conforme as máximas emergentes de uma justiça distributiva" ${ }^{184}$.
\end{abstract}

Assim, por seus pressupostos fáticos próprios a serem tratados no Capítulo 3, item 3.1, e por sua função específica, apresentada no Capítulo 1, de apenas solucionar com justiça uma colisão de direitos, e mais, pelo número considerável de suas hipóteses, encontradas em vários ramos do direito, hipóteses de importância reconhecida - por exemplo, o estado de necessidade, as desapropriações e os danos decorrentes da concessão de medida cautelar - não entendemos correto tratar este instituto como mero "apêndice anômalo", como faz parte da doutrina.

Melhor seria admitir sua autonomia doutrinária, tomando-o como fundamento da responsabilidade civil à semelhança do que fazem Karl Larenz ${ }^{185}$, Inocêncio Galvão Telles $^{186}$, João Matos Antunes Varela ${ }^{187}$, entre outros citados neste trabalho que preconizam a existência tripartite do fundamento da obrigação reparatória: a) a conduta ilícito-culposa, b) os riscos objetivos, c) a colisão entre direitos ${ }^{188}$.

Em relação à autonomia frente aos casos de responsabilidade civil decorrente dos riscos, a confusão é mais provável, porém, apenas aparente.

${ }^{182}$ DE CUPIS, Adriano. Il danno, p. 53. No original: "apêndice anómalo de la resposabilidad civil". No mesmo sentido, ver: VARELA, João Matos Antunes. Das obrigações em geral, § 164, p. 573.

183 MOTA PINTO, Carlos Alberto da. Teoria geral do direito civil, p. 122.

184 CASTILLA, Gustavo Ordoqui. Obligacion de compensar daños causados por conductas lícitas, n. 726, p. 13. No original: "tiene una estructura peculiar, ya que su presupuesto de hecho se da con prescindencia de una conducta ilícito-culposa; y una función específica, pues la suma de dinero debida no es por motivos sancionatorios-resarcitorios, sino más bien 'compensatorios', respondiendo a un criterio que pretende resolver los conflictos de interés conforme a las máximas emergentes de una justicia distributiva”.

185 Derecho de obligaciones, $\S 72$, p. 690 e ss.

186 Direito das obrigações, p. 208 e ss.

187 Das obrigações em geral. 10. ed., § 164, p. 573 e ss.

188 Os autores citados denominam a referida categoria como responsabilidade por atos lícitos, termo já analisado em 2.2. 
Como já visto ${ }^{189}$, a responsabilidade por risco e a responsabilidade decorrente do conflito de direitos prescindem do elemento culpa e, portanto, são espécies do gênero responsabilidade objetiva. Devido a este gênero comum, invariavelmente possuem características semelhantes, já tratadas neste trabalho.

Contudo, responsabilidade pelo risco e a responsabilidade pelo conflito de direitos diferem cabalmente. A primeira diferença a ser ressaltada é que o dano, na responsabilidade por conflito entre direitos, é permitido, enquanto na responsabilidade por risco não. É o que Serpa Lopes denominou “direito de prejudicar"190, para as hipóteses de estado de necessidade, que justificam o prejuízo que alguém possa causar ao direito alheio. Neste, a atividade é permitida, e o dano, na medida da importância e do necessário, também.

Já na responsabilidade por risco, apenas a atividade é lícita, o dano não. Por serem os interesses compatíveis, mesmo que um deles esteja em desvantagem, sofrendo em parte suportável os efeitos do outro, o extravasamento para um dano maior do que o suportável não é permitido pelo ordenamento jurídico.

Neste sentido, o dano na responsabilidade por risco é reprovável e indesejável pelo ordenamento jurídico, enquanto o dano ocorrido na responsabilidade por conflito entre direitos é desejável, ou ao menos tolerável, pois que visa proteger bem maior que ele próprio. No mesmo sentido, Pontes de Miranda aponta, “essa última permissão [de permitir-se o ato danoso] ocorre quanto aos atos em legítima defesa e em estado de necessidade; não, porém, no tocante à responsabilidade pelo risco"191

Outra diferença que pode ser ressaltada é a da existência do risco. $\mathrm{Na}$ responsabilidade pelo risco pré-existe à indenização, necessariamente, uma atividade que apesar de ser permitida pelo ordenamento jurídico, e, portanto lícita, entendeu o legislador ser uma atividade de risco, em que, a qualquer momento, pode haver, mais facilmente, um dano a um sujeito, que a priori é indeterminado e se concentra apenas na ocorrência do dano.

\footnotetext{
${ }^{189}$ Cf. Capítulo 2, item 2.4 deste trabalho.

${ }^{190}$ LOPES, Miguel Maria de Serpa. Curso de direito civil. 9. ed. Rio de Janeiro: Freitas Bastos, 2000. v. I, $\S 387$, p. 542. Cf. AMARANTE, Aparecida. Excludentes de ilicitude civil. Belo Horizonte: Del Rey, 1999. p. 17.

191 PONTES DE MIRANDA, Francisco Cavalcanti. Tratado de direito privado. § 163, p. 234.
} 
Já nos casos de responsabilidade por conflito de direitos, não há risco nenhum. O que existe efetivamente é o dano, permitido pelo legislador e que deve ser reparado. Não há, desta forma, a preexistência de uma situação de perigo, o que há é o dano necessário à proteção de um bem maior.

Nem mesmo as hipóteses de risco exacerbado podem ser confundidas com a responsabilidade por conflito de direitos, pois o dano, nestes casos, continua a ser indesejável $^{192}$. No ordenamento jurídico brasileiro, o risco exacerbado está concretizado, por exemplo, na responsabilidade civil e nas atividades nucleares previstas na Lei $\mathrm{n}$. $6.453 / 77$.

Dessa forma, não trata a responsabilidade pelo conflito entre direitos de reparação fundada em ato que vai contra o ordenamento jurídico (ato ilícito), em que a atividade do agente e também suas repercussões são inaceitáveis perante a sociedade, devendo ser coibidas e prevenidas.

Também não se trata de uma situação perigosa em que a atividade é licita, permitida e aceita pela sociedade, da qual se tira proveito (risco-proveito) ou da qual foi o próprio agente o criador (risco-criado), porém o dano decorrente desta atividade é reprovável e assim dever ser prevenido.

Mas a responsabilidade por conflito de direitos é, sim, de uma reparação que surge de um desequilíbrio no campo da licitude, pelo exercício regular de um direito, incompatível com outro, ao qual por seu valor e importância prevalece, porém, ao ofendido é devida reparação, em virtude de regra de justiça, assim expressa pelo legislador.

Veja que em todas as categorias de fundamentos da responsabilidade civil há, invariavelmente, a noção principal de aceitação de atividades e danos pela sociedade, ou seja, de normalidade civil, a ser definida historicamente, isto é topicamente, considerando o tempo e o espaço em que ocorrem. As condutas aceitas ou não e os danos aceitos ou não pela sociedade pressupõem juízo cultural, na maioria das vezes ainda não incorporado ao ambiente jurídico $^{193}$. Nestes momentos a ciência do direito percebe a sociedade e sua

\footnotetext{
192 BITTAR, Carlos Alberto. Responsabilidade civil nas atividades nucleares. São Paulo: RT, 1982. p 146 e ss. BITTAR, Carlos Alberto. Responsabilidade civil: teoria e prática. 3. ed. Rio de Janeiro: Forense Universitária, 1999. p. 52 e ss.

193 HIRONAKA, Giselda Maria Fernandes Novaes. Responsabilidade pressuposta, Belo Horizonte: Del Rey, 2005 , p. $16,23,67,88$.
} 
cultura de forma direta, por meio da intersecção entre direito e ética, demonstrando o desgaste da concepção que fundamenta a responsabilidade civil, exclusivamente, com base no Direito Positivo ${ }^{194}$.

Todavia, nos limites do presente estudo, por fundar-se no dano e integrar o sistema de responsabilidade civil (por sua finalidade reparatória), mas não se alinhar em nenhuma das espécies existentes (culpa e risco), já que surge da solução determinada $a$ priori pelo legislador ao exercício incompatível de direitos concedidos pelo ordenamento jurídico, propõe-se a responsabilidade civil decorrente do conflito de direitos como um fundamento autônomo da obrigação reparatória, em mesmo nível sistemático da responsabilidade por risco, pois, com ela forma o gênero responsabilidade objetiva.

${ }^{194}$ HIRONAKA, Giselda Maria Fernandes Novaes. Responsabilidade pressuposta, p. 69. 


\section{A RESPONSABILIDADE - ÍNDICES CARACTERIZADORES E APLICAÇÃO}

\subsection{ELEMENTOS}

Determinado o objeto de estudo, a responsabilidade decorrente do conflito de direitos, classificando-a no sistema da responsabilidade civil e diferenciando-a de outros institutos, ou seja, após demonstrar suas relações externas com outros institutos, cumpre tratar de seus elementos, os excludentes à sua aplicação, seus mecanismos de jurisdicização, isto é, suas relações internas, para que se possa determinar a consumação, ou não, de suas conseqüências próprias e comuns.

Estes índices caracterizadores do tipo aproximam ou afastam as situações fáticas do enquadramento legal típico, aqui previsto ${ }^{195}$. Apesar de a responsabilidade por conflito de direitos ser determinada por hipóteses específicas - cujo suporte fático é extremamente determinado - pela indução e abstração de suas espécies, fez-se um estudo das prováveis categorias que regem as suas hipóteses. Pode-se, de certa forma, afirmar ser este o plano da existência da categoria em estudo.

Como nos informa Marcos Bernardes de Mello ${ }^{196}$, analisando a obra de Pontes de Miranda: o plano da existência é "o plano do ser", e que "ao sofrer a incidência da norma jurídica juridicizante, a parte relevante do suporte fático é transportada para o mundo jurídico, ingressando no plano da existência”. Passam por este plano todos os fatos e atos relevantes ao direito, independentemente da qualificação e das conseqüências que receberão posteriormente, por exemplo, lícito, ilícito, nulo, força maior, entre outras.

\footnotetext{
195 LARENZ, Karl. Metodologia da ciência do direito, p. 566.

196 Teoria do fato jurídico, $§ 21$, p. 96.
} 
É um plano de passagem obrigatória. É premissa para análise do fenômeno jurídico. Neste momento, a questão se resume a completude, ou não, do suporte fático exigido pela lei para que este ato ingresse no mundo jurídico e gere, em tese, os efeitos previstos nesta regra.

Propriamente, o plano da existência deve ser observado na ocorrência fática dos elementos da norma, porém, por abstração, buscou-se a forma genérica dos elementos necessários para a caracterização de uma responsabilidade civil ex lege decorrente do conflito entre direitos. Para este fim, partiu-se da postura que tradicionalmente está consolidada na doutrina que, para o surgimento de responsabilidade, deve-se provar o tripé: culpa, dano e nexo. Qualquer aluno, até mesmo os mais descuidados com o estudo, sabe de cor esta concepção de responsabilidade civil, por sua simplicidade e concisão. Parcialmente correta, por referir-se apenas aos casos de responsabilidade subjetiva, como se demonstra em todo este trabalho, o que nos importa neste momento é que ela revela a estrutura básica de toda responsabilidade civil.

Esta estrutura estável, ampliada a todos os casos de responsabilidade civil pode ser reduzida no tripé: conduta-nexo-dano. A conduta é o fator subjetivo que diferencia os vários tipos de responsabilidade. Por exemplo, uma atitude contrária ao ordenamento jurídico que cause dano enseja a responsabilidade subjetiva fundada na culpa, uma atitude de risco, mas ainda permitida pelo ordenamento jurídico, que cause dano enseja a reparação por risco, e por fim, uma atitude em exercício regular de direito, que colide e ofende direito alheio, ao qual o legislador previu indenização, trata-se de responsabilidade por conflito de direitos. Assim, a conduta varia de acordo com o fundamento da responsabilidade a ser invocado.

No entanto, sempre presentes na configuração da responsabilidade civil estão o dano e o nexo que o liga à conduta. São estes os elementos comuns a todas as espécies de responsabilidade civil, restando ao estudo das condutas, individualmente consideradas, a diferença específica. 


\subsubsection{Elementos comuns a todas as espécies de responsabilidade}

\subsubsection{Dano}

Como conseqüência de a impossibilidade do conceito de culpa ocupar o núcleo da responsabilidade civil, abarcando todas as situações que ensejam reparação - o dano passou a ser o elemento determinante de toda obrigação reparatória. Nos dizeres de Antônio Montenegro “(...) modernamente, diz-se que a responsabilidade é a conseqüência jurídica do dano" ${ }^{" 197}$. Desta forma, para que ocorra uma hipótese de responsabilidade civil é necessário que haja um dano, ou na posição taxativa de Henri Lalou "sem dano, não há responsabilidade civil"198,199.

Esta frase, a princípio óbvia e dispensável, encerra uma das verdades mais complexas em todo o estudo da responsabilidade civil, seja qual for o seu fundamento ou suporte fático. Determinar-se a existência de um dano e a sua extensão é um desafio à doutrina e jurisprudência. Isto ocorre pela inexistência nas codificações de uma definição para o que seja dano ${ }^{200}$. Sem a guia legal, doutrina e jurisprudência são debatidas para caracterizá-lo.

Exceção é o código austríaco, que em seu artigo 1.293 dispõe: “O dano é todo prejuízo que alguém sofre em seu patrimônio, nos seus direitos ou na sua pessoa"201.

Sendo a finalidade precípua da responsabilidade civil o restabelecimento da vítima ao estado anterior ao do acidente que a envolveu ${ }^{202}$, o dano, na visão de Clóvis do Couto e Silva, “deve ser mensurado pela diferença entre a situação patrimonial anterior e

197 MONTENEGRO, Antonio Lindenberg C. Responsabilidade civil, § 3, p. 6.

198 LALOU, Henri. Traité pratique de responsabilité civile. 3. ed. Paris: Librairie Dalloz, 1943. p. 85. No original: "Pas de préjudice, pas de responsabilité civile".

199 Em outro sentido, é a orientação do commom law no qual, em alguns casos, o dano não é pré-requisito para existência dos Torts. Cf. ZITSCHER, Harriet Christiane. Introdução ao direito civil alemão e inglês. Belo Horizonte: Del Rey, 1999. p. 153.

200 Esse comportamento se deve ao fato de a maioria dos códigos terem sido fiéis à determinação de Javolenus de que "omnis definitio in iure civili periculosa est" (tradução livre "Toda definição no direito civil é perigosa") demonstrando a preocupação dos juristas com as limitações de qualquer definição e as injustiças que por ocasião dela podem ocorrer.

201 Apud COUTO E SILVA, Clóvis V. do. O conceito de dano no direito brasileiro e comparado. Revista dos Tribunais, São Paulo, n. 667, maio 1991, p. 7.

202 STARCK, Boris; ROLAND, Henri; BOYER, Laurent. Obligations: 1. Responsabilité délictuelle. 4. ed. Paris: Litec, 1991. p. 53. 
posterior à sua existência"203. Para este doutrinador, em concepção mais estrita do dano, o objetivo da responsabilidade civil é o restabelecimento da situação ao status quo ante da ocorrência do fato danoso. Num primeiro momento, dever-se-ia buscar, neste sentido, a reparação in natura, e apenas na sua impossibilidade, a reparação em dinheiro.

De modo mais abrangente, Caio Mário da Silva Pereira define "dano como toda ofensa a um bem jurídico", entendendo esta como "toda lesão à integridade física ou moral da pessoa; as coisas corpóreas ou incorpóreas que são objetos de relações jurídicas; o direito de propriedade como os direitos de crédito; a própria via como a honorabilidade e o bom conceito que alguém desfruta na sociedade"204.

Para integrar o sistema de responsabilidade civil, a doutrina entende que o dano deve ser certo e atual ${ }^{205}$. Atual é o dano que existe ou já existiu "no momento da ação de responsabilidade; certo, isto é, fundado sobre um fato preciso e não sobre hipótese"206.

Por serem propositalmente indefinidos, para melhor acompanharem as variações sociais, esta ordem de conceitos sofre ataques e questionamentos de toda ordem, variando, por conseguinte, de acordo com o tempo. Dá-se como exemplo de alterações as noções de dano por ricochete (dommage par ricochet) ${ }^{207}$, a perda de uma chance (perte d'une (chance $)^{208}$ entre outras ${ }^{209}$.

Deve-se ressaltar, também, não ser o dano relacionado exclusivamente com a ilicitude ou antijuridicidade, conforme aponta a doutrina há algum tempo. Conforme demonstrado neste trabalho, nem todo dano com relevância jurídica é decorrente de atos ilícitos. A ressalva é feita por Carlos A. Ghersi: “o dano começa a se desprender de sua causa de antijuridicidade e culpabilidade, consolidando-se autonomamente, o dano, é somente isto: o dano"210. No mesmo sentido, afirma Silvio Neves Baptista: "fato danoso

${ }^{203}$ COUTO E SILVA, Clóvis V. do. O conceito de dano no direito brasileiro e comparado, p. 8.

${ }^{204}$ PEREIRA, Caio Mário da Silva. Responsabilidade civil, p. 53.

205 PEREIRA, Caio Mário da Silva. Responsabilidade civil, p. 39.

${ }^{206}$ LALOU, Henri. Traité pratique de responsabilité civile, p. 87.

207 STARCK, Boris; ROLAND, Henri; BOYER, Laurent. Obligations, p. 82.

208 SAVI, Sérgio. Responsabilidade civil por perda de uma chance. São Paulo: Atlas, 2006; PEREIRA, Caio Mário da Silva. Responsabilidade Civil, p. 41.

209 Algumas outras novas concepções de dano que alteram de forma significativa os conceito de atualidade e certeza pode ser conferidas em PEREIRA, Caio Mário da Silva. Responsabilidade Civil, p. 39 e ss.

${ }^{210}$ GHERSI, Carlos A. Responsabilidad por actos lícitos, p. 477. No original "el daño se comienza a desprender de su causa de antijuidicidad y culpabilidad, consolidándose autónomamente, el daño, es eso y sólo eso: daño". 
não importa só numa ilicitude, podendo em determinados casos representar também fato lícito, ou permitido pelo direito" ${ }^{211}$.

É o caso deste estudo. O indivíduo que, por exemplo, entra em prédio vizinho para fazer reparo no seu e necessita danificar aquele, pode fazê-lo, desde que indenize plenamente o vizinho ${ }^{212}$. O dano, neste caso, nos limites de sua necessidade, é causado por atividade lícita, porém indenizável.

Não se pode negar a existência de um dano com relevância jurídica nestes casos. Conforme Adriano de Cupis "existe um posicionamento fixo no dito tradicional dannum quod iniuria fit; mas a verdade é que o dano antijurídico não é mais que uma espécie, pura, repetimos, particularmente conspícua, do dano em senso jurídico"213. Continua o mesmo doutrinador:

\begin{abstract}
"Quando um interesse é preterido, verifica-se um prejuízo, um dano; e se este dano, proveniente de causa estranha ao sujeito que o sofreu, produz reação jurídica a favor deste sujeito, este é sempre, com toda evidência, um dano em senso jurídico, independentemente de sua antijuridicidade" 214 (grifos nossos).
\end{abstract}

Apenas um falso preconceito justifica esta petição de princípio de, na discussão dos danos ressarcíveis, se excluir a categoria dos atos lícitos danosos ${ }^{215}$.

A complexidade da questão nos remeteria a vários outros pontos de muito interesse ao estudo das responsabilidades em geral, contudo, por ora, e nos limites deste trabalho, fixa-se entendimento no mesmo sentido de Silvio Neves Baptista, para o qual dano é "o fato jurídico causador de prejuízo ou violador de direito de outrem, em virtude do qual o ordenamento atribui a alguém o dever de reparação, que tenha sido o prejuízo ou a violação do direito causado por um fato lícito ou ilícito"216.

211 BAPTISTA, Silvio Neves. Ensaio sobre a teoria do fato danoso, p. 51. No mesmo sentido, cf. STIGLITZ, Gabriel A.; ECHEVESTI, Carlos A. El daño resarcible, In: ITTURRASPE, Jorge Mosset. Responsabilidad civil. Buenos Aires: Hamurabi, 1997. p. 213.

212 Art. 1.313 do Código Civil.

213 DE CUPIS, Adriano. Il danno, p. 20. No original: “derivirebbe dall'aver la mente esclusivamente compresa dal tradizionale dannum quod iniuria fit; mas il vero è che il danno antigiuridico non è più che una specie, sai pure, ripetiamo, particolarmente cospicua, del danno in senso giuridico".

${ }^{214}$ DE CUPIS, Adriano. Il danno, p. 20. No original: "Quando un interesse viene colpito, si verifica un pregiudizio, un danno; e se questo danno, provenendo da causa estranea al soggetto che lo subisce, è produttivo de reazione giuridica a favore di questo stesso soggetto, esso è sempre, com tutta evidenza, un danno in senso giuridico, independentemente dalla sua antigiuridicità".

215 RUBINO, Domenico. La fattispecie e gli effetti giuridici preliminari, p. 205 e DE CUPIS, Adriano. Il danno, p. 21.

216 BAPTISTA, Silvio Neves. Ensaio sobre a teoria do fato danoso, p. 51. 
Outro elemento necessário para que se configure a responsabilidade civil, e $a$ fortiori, a responsabilidade civil por conflito de direitos, é o nexo de causalidade entre a conduta do agente e o dano ocorrido.

Nas palavras de Jorge Mosset Itturraspe “A denominada relação de causalidade se refere à vinculação que deve existir entre um fato e o dano, para que o autor deste comportamento deva indenizar o prejuízo" ${ }^{217}$. Este vínculo, o nexo, é o liame entre a anterior conduta do agente, também chamada fase subjetiva, e o posterior dano, fase objetiva $^{218}$. A relação deve ser, invariavelmente, de causa e efeito entre a conduta e o dano.

A análise do nexo é de vital importância para a responsabilidade civil, pois determina: no pólo subjetivo, os sujeitos que concorreram para a existência do dano e, no pólo objetivo, a extensão do dano a ser ressarcido.

No caso da responsabilidade por conflito de direitos, além da importância genérica à toda responsabilidade, acresce-se o fato de que apenas no âmbito das relações causais é que serão argüidas as excludentes deste tipo de responsabilidade como o caso fortuito, culpa exclusiva da vítima entre outras ${ }^{219}$.

Muitas são as teorias que tentaram determinar a natureza e extensão do nexo de causalidade $^{220}$, porém a predominante, hoje, é a chamada teoria da causalidade adequada $^{221}$. Para esta doutrina, considera-se causa todo fato ou conduta o qual tem por conseqüência normal e típica aquele dano ${ }^{222}$.

${ }^{217}$ ITTURRASPE, Jorge Mosset. Responsabilidad civil, § 45, p. 106. No original: "La denominada relación de causalidad refiere a la vinculación que debe existir entre un hecho y el daño, para que el autor de ese comportamiento deba indemnizar el perjuicio".

${ }^{218}$ DÍAZ, Julio Alberto. Responsabilidade coletiva. Belo Horizonte: Del Rey, 1998. p. 55.

${ }^{219}$ Sobre este assunto cf. Capítulo 3, item 2.2.

${ }^{220}$ Por todas cf. PEREIRA, Caio Mário da Silva. Responsabilidade Civil, § 68, p. 77 e ss.

${ }^{221}$ CAVALIERI FILHO, Sergio. Programa de responsabilidade civil, p. 76.

${ }^{222}$ MONTENEGRO, Antonio Lindenberg C. Responsabilidade civil, p. 335. 
Trata-se de uma questão de previsibilidade, potencialidade de previsibilidade do dano $^{223}$. Faz-se, após a ocorrência do dano, uma prognose póstuma ${ }^{224}$, colocando-se no momento da ação e determinando a probabilidade de ocorrência do dano e sua extensão, tendo-se sempre em vista a importância do fato, de suas conseqüências comuns e típicas e a situação na qual estão insertos estes elementos.

\title{
Nas palavras de Caio Mário da Silva Pereira:
}

\begin{abstract}
"o problema da relação de causalidade é uma questão científica de probabilidade. Dentre os antecedentes do dano, há que se destacar aquele que está em condições de necessariamente tê-lo produzido. Praticamente em toda ação de indenização, o juiz tem de eliminar fatos menos relevantes, que possam figurar entre os antecedentes do dano. São aqueles que seriam indiferentes à sua efetivação. O critério eliminatório consiste em estabelecer que, mesmo na sua ausência, o prejuízo ocorreria. Após este processo de expurgo, resta algum que, 'no curso normal das coisas', provoca um dano dessa natureza. Em conseqüência, a doutrina que se constrói neste processo técnico se diz da 'causalidade adequada', porque faz salientar na multiplicidade de fatores causais, aquele que normalmente pode ser o centro do nexo de causalidade, eliminado os demais ${ }^{, 225,226}$.
\end{abstract}

O Código Civil Português em seu artigo 563 elucida a questão do nexo de causalidade afirmando que "A obrigação de indenização só existe em relação aos danos que o lesado provavelmente não teria sofrido se não fosse a lesão".

Henri de Page $^{227}$ afirma haver um caráter de necessariedade da ocorrência do dano em face da conduta, reforçando a idéia base da relação de causa e efeito entre a conduta e o dano.

Como ilustração, pode ser citado o caso daquele que é atingido por soco e, ao cair, bate a cabeça em um hidrante e vem a falecer. Pela teoria da causalidade adequada, apenas é possível ao que agrediu com o soco prever os danos relacionados a ele. Neste caso, a conduta do indivíduo está diretamente relacionada aos danos faciais causados pelo soco. O evento morte escapa aos seus atos e por isso, dele está isento de responsabilidade

${ }^{223}$ No caso da responsabilidade subjetiva, a previsibilidade que se faz é sobre os efeitos normais da conduta danosa, na responsabilidade objetiva, o prognóstico é feito sobre a finalidade da norma vulnerada (MONTENEGRO, Antonio Lindenberg C. Responsabilidade civil, p. 335.).

${ }^{224}$ DÍAZ, Julio Alberto. Responsabilidade coletiva, p. 75.

${ }^{225}$ PEREIRA, Caio Mário da Silva. Responsabilidade Civil, § 68, p. 79.

${ }^{226}$ Pode-se afirmar que a teoria da causalidade adequada é uma variação da teoria da causa eficiente apenas quanto aos critérios de eleição: na eficiente, escolhe-se a mais importante para o dano (vê-se o dano já ocorrido e a necessidade de sua reparação), na adequada, escolhe-se a causa que provavelmente daria tal dano e indeniza-se nesta medida.

${ }^{227}$ DE PAGE, Henri. Traité elémentaire de droit civil Belge. Paris: Sirey, 1934. t. II, p. 813. No mesmo sentido, ver: PEREIRA, Caio Mário da Silva. Responsabilidade Civil, § 70, p. 80. 
por não haver nexo. Entretanto, cumpre ressaltar, à semelhança de que faz Jorge Mosset Itturraspe, que

\begin{abstract}
“a mediação da eficiência não é uma questão matemática, rígida, suscetível de ser traduzida em uma fórmula. Possui tonalidades intermediárias, matizes, dos direitos humanos, que levem ser analisados caso a caso, com especial atenção à tipicidade ou atipicidade dos efeitos., 228
\end{abstract}

Complementa o mesmo doutrinador: "Os esquemas expostos poderão ser mais ou menos inteligíveis, mas não se prestam, nem de longe, para desqualificar a tendência, bastante céptica, que aconselha reutilizar as teorias e dar ênfase na observação das circunstâncias próprias de cada caso"229.

Confirma-se a idéia de que, no direito, a causa é determinada mais pelas circunstâncias práticas do que por uma formula teórica ${ }^{230}$. Esta posição em que pese a melhor adaptação à realidade gera abusos, ou como afirma Julio Alberto Díaz "na verdade, na prática, costuma selecionar arbitrariamente uma dessas condições necessárias denominando-a "causa",231 . No entanto, em que pese a fragilidade de qualquer formulação teórica neste campo, deve-se sempre tê-la ao menos como guia das decisões.

\title{
3.1.2 Elementos específicos (differentia especifica)
}

Além dos elementos comuns aos outros tipos de responsabilidades, a responsabilidade por conflito entre direitos possui elementos próprios e específicos que a diferenciam das outras categorias.

${ }^{228}$ ITTURRASPE, Jorge Mosset. Responsabilidad civil, p. 111. No original: "la mediación de la 'eficiencia' no es una cuestión matemática, rígida, susceptible de ser planteada como una fórmula. Tiene las tonalidades intermedias, grises, de los hechos humanos, que deben ser analizados caso por caso, con especial atención a la tipicidad o atipicidad de los efectos".

229 ITTURRASPE, Jorge Mosset. Responsabilidad civil, p. 117. No original: "Los esquemas expuestos podrán ser más o menos inteligibles, pero no alcanzan, ni por mucho, para descalificar a la tendencia, un tanto escéptica, que aconseja rehusar las teorías y poner el énfasis en la observación de las circunstancias propias de cada caso".

230 MONTENEGRO, Antonio Lindenberg C. Responsabilidade civil, § 199, p. 334; PEREIRA, Caio Mário da Silva. Responsabilidade civil, § 73, p. 82.

${ }^{231}$ DÍAZ, Julio Alberto. Responsabilidade coletiva, p. 59. 
Estes elementos próprios da responsabilidade por conflito de direitos relacionamse, principalmente, com o ato gerador da responsabilidade, mas também dizem respeito aos outros caracteres da responsabilidade civil.

\subsubsection{Exercício regular de um direito}

A responsabilidade civil ex lege por conflito entre direitos surge, num primeiro momento, do exercício regular de um direito. Trata-se, desta forma, do exercício de um poder jurídico permitido e garantido pelo ordenamento jurídico de forma legítima, isto é, normalmente, em seus fins sociais traçados para ele ou para aquele que age de boa-fé ${ }^{232}$.

Não há, desta forma, qualquer ilicitude na conduta daquele que colide com direito alheio quando age conforme o direito. E em que pese não haver ilicitude, e, por conseqüência não haver responsabilidade subjetiva do agente, há a responsabilidade objetiva específica para algumas situações especiais escolhidas pelo legislador em que o exercício regular de direito causa dano a outrem.

Isto ocorre, pois que o exercício de direito, expresso pelo brocardo qui iure suo utitur neminem laedit, não é absoluto, mas ao contrário, está limitado por outros $\operatorname{princípios~}^{233}$.

No caso da responsabilidade por conflito de direitos, a contraposição ocorre diretamente com o princípio do neminem laedere (ou alterum non laedere). A proibição de lesar tem eficácia mesmo em se tratando de atos em exercício de direito ${ }^{234}$.

${ }^{232}$ AMARANTE, Aparecida. Excludentes de ilicitude civil. Belo Horizonte: Del Rey, 1999. p. 76.

${ }^{233}$ Orlando Gomes (Introdução ao direito civil, p. 131) afirma que este brocardo decorre de uma diretriz, fruto do individualismo jurídico.

${ }^{234}$ A diretriz do alterum non laedere também não é absoluta. René Savatier, (Traité de la responsabilité civile em droit français. Paris: Librairie Générale de Droit et de Jurisprudence, 1939. t. I, p. 51-52), em concordância com o expresso em todo este trabalho, reconhece o direito de causar prejuízo, determinado nos seguintes casos: direito de concorrência, direito de defesa (legítima defesa, estado de necessidade, direito de estar em juízo), direito de promiscuidade e de vizinhança, direito de expressão do pensamento ou de informação, direito de abstenção. No mesmo sentido, cf. LOPES, Miguel Maria de Serpa. Curso de direito civil, v. V, p. 158-159. 
Outro princípio que pode ser invocado para justificar a indenização decorrente de um exercício regular de um direito é o de que quem exercita direito deve suportar o ônus que acompanha seu exercício (ubi commoda, ibi incommoda) ${ }^{235}$. Desta forma, quem pretende exercer seu direito, deve assumir a indenização dos danos produzidos por seu ato.

Prejudicado está, desta forma, o princípio qui iure suo utitur neminem laedit ${ }^{236}$, que apenas pode ser aplicado com rigor em sistemas hermeticamente perfeitos, sem antinomias ou lacunas, isto é, doutrinariamente irretocáveis, em pleno compasso com a sociedade que rege.

Como está demonstrado historicamente, a impossibilidade de um sistema assim, por mais que a doutrina se dedicasse a tal tarefa, a aplicação do direito puro, ou melhor, o exercício regular de um direito, individualmente considerado, olvidando-se de qualquer reflexo social que ele possa ter, como dita o princípio em questão, muitas vezes é causa de dano injusto, ensejando, para mitigá-lo, a aplicação do brocardo summum ius summa iniuria. É o que Pontes de Miranda formulou como tese, antítese e síntese, afirmando:

\begin{abstract}
"a propósito de exercício dos direitos, houve o princípio-tese da absolutidade do exercício dos direitos, com o aforismo romano Qui iure suo utitur neminem laedit (ou Nemo iniuria facit qui iure suo utitur). O princípio-antítese foi o summum ius summa iniuria. A síntese operou-se pela inclusão do abuso do direito na classe dos atos ilícitos, ou empregando-se regra jurídica de inclusão, por meio de enunciado proibitivo,"237.
\end{abstract}

Assim, o exercício regular de direito não pode ser tomado como absolutamente isento de qualquer limitação ou sanção que vise restabelecer uma situação que ele cause, como se pretende muitas vezes ${ }^{238}$. Pode-se afirmar, desta forma, que o exercício regular de um direito, lícito, não gera indenização pelo princípio genérico da responsabilidade civil subjetiva previsto no artigo 186, porém, em algumas situações previstas pelo legislador, nas quais o exercício colide com outro direito, há a reparação.

235 Este princípio, em verdade, é próprio dos casos de responsabilidade objetiva.

236 Tradução livre: "Quem age de acordo com direito seu a ninguém lesa".

237 PONTES DE MIRANDA, Francisco Cavalcanti. Tratado de direito privado, p. 336. Pontes trata de uma das soluções ao exercício danoso de um direito, que é a extensão do conceito de abuso de direito, classificando-o como ilícito e, portanto, descaracterizando-o como exercício regular de um direito. No texto, trata-se de outra situação que se vale das mesmas premissas, mas por não haver qualquer irregularidade da conduta, a conclusão é diversa da apresentada, podendo ser resumida: a síntese operou-se pela indenização do direito menos valorado.

${ }^{238}$ Outras limitações ao exercício irrestrito do direito são, por exemplo, a necessidade de atendimento de sua função social, o não exercício com fim apenas de lesar alguém (emulatio) e as limitações temporais de inércia no seu exercício (prescrição e decadência). 
Pelo que foi exposto, não há, na configuração da responsabilidade por conflito de direitos, qualquer menção à culpa ou mesmo dolo do agente em seu ato, pois que o seu ato não rompe com o ordenamento jurídico e, portanto, não é ilícito. A licitude e lisura de sua conduta está expressa até mesmo pela excludente de responsabilização subjetiva do artigo 188 do Código Civil.

Também não há que se falar em abuso de direito, pois que o abuso é, na lição de Orlando Gomes o uso anormal de direito ${ }^{239}$. Esta concepção vem reforçada e pacificada ${ }^{240}$ no Código Civil vigente ao caracterizar o abuso de direito como ato ilícito em que o titular de um direito, ao exercê-lo, excede manifestamente os limites impostos pelo seu fim econômico ou social, pela boa-fé ou pelos bons costumes ${ }^{241}$.

No tipo da responsabilidade objeto deste estudo, o agente se porta secundum ius, isto é, em pleno acordo com a determinação dada pela lei. Decorre esta responsabilidade de uma atividade lícita.

Está-se diante, na verdade, de um conflito de atividades lícitas, nas quais, não há culpa, não há abuso de direito, mas que por serem inconciliáveis e excludentes uma da outra, a mais importante ou necessária deve sobrepor-se à outra, porém, por ser a outra atividade também lícita e ter sido violada, esta é devido, por determinação do legislador, reparação compensatória.

\subsubsection{Conflito de direitos}

Outro elemento fundamental para que haja a responsabilidade por conflito de direitos é, obviamente, a própria colisão entre direitos envolvidos. A colisão decorre em virtude de deficiências tanto no campo econômico (pois que as utilidades previstas como

\footnotetext{
${ }^{239}$ Orlando Gomes (Introdução ao direito civil, p. 132) afirma variarem as noções de abuso de direito de acordo com sua concepção: para a corrente subjetivista o abuso seria o "uso do direito com o fim de causar dano a outrem", para os objetivistas, seria um "desvio em seu exercício, porque falta ao titular legítimo interesse para exercê-lo daquele modo, ou porque sua destinação econômica ou social foi frustrada". Cabe ressaltar que, seja numa ou noutra concepção, não configura abuso de direito a conduta que origina a responsabilidade por conflito de direitos.

${ }^{240}$ PODESTÁ, Fábio Henrique. Direito das obrigações: teoria geral e responsabilidade civil. 5. ed. São Paulo: Atlas, 2005. p. 278.

${ }^{241}$ Artigo 187 do Código Civil.
} 
conteúdo dos direitos, são muitas vezes escassas), como deficiências no campo jurídico, quando o ordenamento jurídico concede direitos opostos ou concorrentes sobre um mesmo bem ou valor ${ }^{242}$.

Isto ocorre pois, em abstrato, as concessões determinadas pelo ordenamento jurídico não são bem delimitadas, ocorrendo interpenetrações entre as esferas jurídicas. É o que se passa, por exemplo, no caso do jornalista, que tem o direito de informar, e o da pessoa investigada, que possui o seu direito à intimidade.

O Código Civil Português, admitindo a possibilidade do conflito entre atividades lícitas, com muita sabedoria, preferiu regulá-lo ao invés de, ilusoriamente, negá-lo. Com a nomenclatura de "colisão de direitos", assim se expressa em seu artigo 335:

\footnotetext{
“1. Havendo colisão de direitos iguais ou da mesma espécie, devem os titulares ceder na medida do necessário para que todos produzam igualmente o seu efeito, sem maior detrimento para qualquer das partes. 2. Se os direitos forem desiguais ou de espécie diferente, prevalece o que deva considerar-se superior."
}

Demonstra-se não haver mais, no sistema jurídico português, o mito da perfeição do ordenamento jurídico. Aparecida Amarante sobre o citado artigo complementa: "Percebe-se que a orientação do legislador português fugiu ao individualismo predominante no Código Napoleônico e nos Códigos a ele posteriores, consagrando a importância da coesão e harmonia dos direitos individuais, dentro de uma visão socializante do direito" ${ }^{243}$. A colisão, portanto, não deve ser negada, mas, a exemplo do Código português, deve ser regulada.

In casu, há conflito de direitos no qual, para sua justa solução, o legislador determinou que, na impossibilidade de concordância prática desses, um se sobreponha ao outro, sendo, porém, devida, ao lesado, justa reparação dos danos decorrentes de seu direito ofendido.

Nesta ordem de conceitos, há que se esclarecer a premissa de que, para fins do presente estudo, considera-se a existência primeira de direitos concedidos pelo ordenamento jurídico que colidem abstratamente, para, posteriormente, considerar-se a solução oferecida, seja pelo legislador, seja pelo julgador, conforme o tipo de responsabilidade por conflito de direitos a que se refere.

\footnotetext{
242 Cf. Capítulo 1.

243 AMARANTE, Aparecida. Excludentes de ilicitude civil, p. 115.
} 
Tal ponderação é importante vez que, ao tratar a situação jurídica considerando a existência simultânea do conflito e de sua solução dada pelo legislador, não há que se cogitar de conflito. Neste sentido, não seria possível considerar tais hipóteses como colisão de direitos, muito menos aproximá-las da responsabilidade ex iudicio por conflito de direitos, vez que, disciplinada pelo legislador, a solução, como deve ocorrer, encerraria o conflito.

Desta forma, faz-se a opção de considerar a colisão de tais direitos, mesmo que abstrata, como primeira, e a solução legislativa, como posterior.

Esta ponderação oferece também, como conseqüência, o fato de que apenas a colisão de direitos regularmente reconhecidos é passível de enquadrar-se como hipótese de responsabilidade civil por conflito de direitos. Desta forma, excluem-se da apreciação os meros interesses que não são objetos de norma jurídica que os transformaria em $\operatorname{direitos}^{244}$.

Isto ocorre até mesmo porque, por serem as hipóteses deste tipo específico de responsabilidade todas previstas em lei, os interesses envolvidos sempre são objetos de norma, transformando-os em direitos, afastando a concepção de que as hipóteses em estudo não se tratariam de conflito de direitos, mas apenas de colisão de interesses ${ }^{245}$.

A colisão de meros interesses não se sustenta na hipótese em estudo, pois, pela estrutura de sua gênese, a responsabilidade civil ex lege por conflito de direitos decorre da imposição legal de limites ${ }^{246}$, por meio do ordenamento jurídico, a um direito existente.

Assim, todos os interesses eventualmente envolvidos estão tutelados e positivados, tornando imprópria a utilização do vocábulo interesse para designar os direitos em conflito. Assim, por exemplo, na concessão da passagem forçada, o direito à propriedade é contraposto ao acesso útil e a função social da propriedade.

244 GIORGI, Giorgio. Teoria delle obligazioni nel diritto moderno italiano, p. 283 afirma que o direito significa o gozo da utilidade garantido por lei; simples interesse quer significar o gozo de utilidade não garantido por lei.

245 BAPTISTA, Silvio Neves. Teoria geral do dano: de acordo com o novo Código Civil brasileiro. São Paulo: Atlas, 2003. p. 56.

246 AMARAL, Francisco. Direito civil: introdução. 5. ed. rev., atual. e aum. Rio de Janeiro: Renovar, 2003. p. 208. 
Por fim, vislumbra-se que as hipóteses de responsabilidade por conflito de direitos podem decorrer tanto de direitos subjetivos em sentido estrito como os direitos potestativos.

A despeito de toda a discussão envolvendo a definição de direito subjetivo ${ }^{247}$, direito subjetivo, na lição de Carlos Alberto da Mota Pinto, "É o poder de exigir ou pretender de outrem um determinado comportamento positivo (acção) ou negativo (abstenção ou omissão) $)^{248}$.

Para Miguel Reale, existe direito subjetivo quando "a situação subjetiva (possibilidade de ser, pretender ou fazer algo, de maneira garantida, nos limites atributivos das regras de direito) implica a possibilidade de uma pretensão, unida à exigibilidade de uma prestação ou de um ato de outrem"249. Resumidamente, na lição do mesmo doutrinador "direito subjetivo é a possibilidade de exigir-se, de maneira garantida, aquilo que as normas de direito atribuem a alguém como próprio"250.

Origina-se a responsabilidade por conflito de direitos também nas hipóteses de direito potestativo. Para Carlos Alberto da Mota Pinto, direito potestativo "são poderes jurídicos de, por um acto livre de vontade, só de per si ou integrado por uma decisão judicial, produzir efeitos jurídicos que inelutavelmente se impõem à contraparte"251. Assim, é o caso do exercício do direito potestativo de exigir servidão de passagem, previsto no artigo 1.285 do Código Civil. O exercício do direito se impõe à outra parte que não poderá se opor, mas que terá indenizado o seu direito ofendido.

\subsubsection{Inconciliação prática}

Apenas surge a responsabilidade por conflito de direitos caso haja, também, a necessária inconciliação prática entre os direitos em conflito.

\footnotetext{
${ }^{247}$ Para tais considerações, remetemos às lições de AMARAL, Francisco. Direito civil, p. 187 e ss.

248 MOTA PINTO, Carlos Alberto da. Teoria geral do direito civil, p. 172.

249 REALE, Miguel. Lições preliminares de direito. 26. ed. São Paulo: Saraiva, 2002. p. 261.

${ }^{250}$ REALE, Miguel. Lições preliminares de direito, p. 262.

251 MOTA PINTO, Carlos Alberto da. Teoria geral do direito civil, p. 174.
} 
A concordância prática entre os direitos ocorre quando todos os direitos podem ser exercitados sem que haja conflito entre eles. É o que acontece, por exemplo, com o direito do proprietário de uma casa e o daquele que a locou. Estes direitos, se exercidos de forma regular, têm a possibilidade de convivência harmoniosa.

Já a inconciliação prática decorre da impossibilidade de exercício simultâneo dos direitos pelos seus titulares em que, necessariamente, o exercício de um ofenda, ou limite, o exercício do outro ${ }^{252}$.

Desta forma, o exercício unido à inconciliação confunde-se com a existência do próprio dano. Como ilustração, tem-se o proprietário de prédio que necessite de reformas e exerce seu direito de reparar seu prédio. Se, adentrando em prédio vizinho, efetua sua reforma sem causar dano algum, houve concordância prática dos exercícios dos direitos e não há que se falar em reparação. Entretanto, se para a reparação do prédio, foram necessárias, por exemplo, escavações que tornaram necessária a saída do vizinho para um hotel, ou que o impediram de exercer o seu comércio naquele lugar, o vizinho que está consertando seu prédio deve indenizar, pois que o exercício, mesmo que regular, de seu direito é inconciliável com o de seu vizinho, causando-lhe dano que deve ser indenizado ${ }^{253}$.

Enquanto não há utilidade simultânea do bem ou valor, não surge o conflito e não há a responsabilidade, isto é, enquanto não são os direitos exercidos pelo seus titulares, não surge a hipótese de indenização.

A inconciliação prática demanda solução, pois, como já se afirmou alhures, a discordância em abstrato pode ocorrer, mas, em concreto, a regra da coerência do ordenamento jurídico deve prevalecer.

\subsubsection{Solução legislativa}

A responsabilidade por conflito de direitos lato sensu pode decorrer tanto da opção legislativa, como da solução judicial como exposto no Capítulo 1, item 1.2.

252 Sobre as causas da impossibilidade de conciliação prática, remetemos ao Capítulo 1.

253 Artigo 1.313 do Código Civil. 
Invariavelmente, é necessária esta solução, seja qual for a via adotada, para que seja atendida a regra de coerência em relação ao sistema jurídico.

Este estudo, no entanto, trata apenas de indenizações previstas, a priori, pelo legislador, na necessidade de solução de um conflito entre direitos, à qual aqui se denomina responsabilidade civil ex lege por conflito de direitos.

Assim, é da sua natureza a origem legislativa, pois que este tipo de indenização decorre da opção do legislador que, ao prever um conflito entre direitos, disciplinou-o, prevendo à parte prejudicada reparação. Desta forma, este tipo específico de responsabilidade civil, objeto deste estudo, há que provir, caso a caso, especificadamente, de um comando legal.

Não se socorre, desta forma, em que pesem os esforços da doutrina, de um princípio genérico nos moldes do artigo 186 para a responsabilidade subjetiva ou do artigo 927 para a responsabilidade objetiva na espécie risco. A responsabilidade objetiva por conflito entre direitos decorre apenas quando da previsão expressa do legislador.

Este receio em se admitir um principio genérico para os casos de responsabilidade objetiva por conflito de direitos decorre, ainda, da fragilidade da doutrina em estabelecê-lo de forma satisfatória ${ }^{254}$.

No entanto, à semelhança do ocorrido com a responsabilidade subjetiva, que, num primeiro momento, era concedida apenas em ações específicas e, posteriormente, foi, por meio da Lex Aquilia, foi concedido a ele um princípio genérico. E no último século em que movimento semelhante ocorreu com a responsabilidade por risco, passando de previsões específicas caso a caso e agora, com o Código Civil de 2002, teve seu princípio previsto ${ }^{255}$ no parágrafo único do artigo $927^{256}$. Com o apoio da doutrina, a responsabilidade por conflito de direitos deverá percorrer o mesmo caminho, hoje limitado às hipóteses pormenorizadas, caso a caso, na legislação.

254 STOCCO, Rui. Responsabilidade civil pela prática de atos lícitos. Revista dos Tribunais, v. 731, set. 1996. p. 86 e ss.

255 HIRONAKA, Giselda Maria Fernandes Novaes. Responsabilidade pressuposta, p. 140 e ss.

256 Art. 927: parágrafo único: Haverá obrigação de reparar o dano, independentemente de culpa, nos casos especificados em lei, ou quando a atividade normalmente desenvolvida pelo autor do dano implicar, por sua natureza, risco para os direitos de outrem. 
Eliseu Figueira aponta que: "Há que se substituir a técnica de elaboração do ordenamento, segundo o método da tipicidade, pela formulação de princípios gerais que retirem aos tipos da responsabilidade objectiva o caráter de normas excepcionais" 257 . Contudo, por ora, diante desta inconveniência e impossibilidade, confia-se ao legislativo, nos casos da responsabilidade ex lege, e ao judiciário no caso das ex judicio, a tarefa de avaliar, caso a caso, as hipóteses de que, sem culpa do agente, este deva indenizar.

Ressalte-se, porém, que com o princípio genérico, falar-se-á apenas numa forma de responsabilidade por conflito de direitos, a solucionada genericamente pelo legislador, porém determinada, caso a caso, pelos aplicadores do direito.

\subsubsection{Sobreposição do direito mais importante}

Diante da impossibilidade de coexistência entre os direitos, cabe ao legislador adjudicar. Há, desta forma, a preservação de um dos direitos envolvidos no conflito em detrimento de outro.

A determinação, pelo legislador ${ }^{258}$, de qual dos direitos em conflito deve prevalecer, é feita baseada em critérios de necessidade e importância. Esta é, porém, questão complexa, qual dos direitos deve prevalecer?

Clóvis Beviláqua, prevendo a existência no ordenamento de tais conflitos, afirma que "há situações, em que o direito de um indivíduo se acha em conflito com o direito de outro, e o conflito se há de resolver pelo desaparecimento ou cessação transitória do direito menos valioso do ponto de vista ético e humano"259.

Pontes de Miranda, versando sobre as várias formas de atos-fatos indenizatórios $^{260}$, afirma que na solução dos casos de estado de necessidade, a desapropriação, entre outros, como os em tela, importa o princípio do interesse mais

\footnotetext{
${ }^{257}$ FIGUEIRA, Eliseu. Renovação do sistema de direito privado. Lisboa: Editora Caminho, 1989. p. 202-203.

${ }^{258}$ Ou pelo juiz nos casos de responsabilidade ex iudicio por conflito de direitos.

259 BEVILÁQUA, Clóvis. Código Civil dos Estados Unidos do Brasil comentado, v. I, p. 346.

260 PONTES DE MIRANDA, Francisco Cavalcanti. Tratado de direito privado, p. 437.
} 
relevante. Cita como exemplo os casos em que o interesse público se contrapõe ao particular $^{261}$.

Deve haver por parte do legislador a ponderação entre os valores em conflito, determinando que o mais importante prevaleça e ao menos valorado seja devida reparação.

A operação assemelha-se, como defendemos alhures ${ }^{262}$, aos casos em que o julgador vale-se da ponderação e seus subprincípios: da adequação e da necessidade e o da proporcionalidade em sentido estrito ${ }^{263}$, para que, no conflito de direitos, contrapostos verifique-se qual interesse, abstratamente do mesmo nível, tem o maior peso no caso concreto. O juiz ou legislador devem considerar qual o ponto ótimo de equilíbrio entre o que se dá a alguns e se retira de outros, e como ponderar os valores em jogo ${ }^{264}$.

Tem-se assim que, por exemplo, no conflito entre o interesse público em inundar determinadas terras para a construção de uma usina hidrelétrica e o interesse individual do proprietário das terras, há que prevalecer, por sua importância, o interesse da coletividade, mas está ressalvada, pela perda de seu direito, a indenização ao proprietário das terras inundadas.

Outra importante guia que é, e deve sempre ser, utilizada na consideração de qual o direito a se sobrepor refere-se à preferência pelo princípio da dignidade da pessoa humana, como fundamento da República, especialmente no cotejo com direitos patrimoniais. Nesse sentido, as situações jurídicas existenciais deverão prevalecer sobre as jurídicas patrimoniais $^{265}$.

Relembre-se, não há no surgimento deste tipo de responsabilidade, com a conduta danosa, o rompimento do ordenamento jurídico. Não se trata de juízos entre um

${ }^{261}$ Pontes de Miranda, tratando do exercício regular de direitos, afirma que a solução de um choque entre direitos decorre da aplicação de dois princípios: o princípio da prioridade no tempo e o princípio da igual sorte. $\mathrm{O}$ princípio da prioridade no tempo (Prior tempore, potior iure) é aquele pelo qual é titular do direito o indivíduo que primeiro o exercer. Para o autor, ocorre nos direitos reais. O princípio da igual sorte é aquele em que todos sofrem com a colisão, presente mais nos direitos pessoais e de crédito (Tratado de direito privado, p. 335-336).

${ }^{262}$ Cf. Capítulo 1 sobre solução do conflito.

${ }^{263}$ ALEXY, Robert. Ponderação, jurisdição constitucional e representação popular. In: SARMENTO, Daniel; SOUZA NETO, Cláudio Pereira de. A constitucionalização do Direito. Rio de Janeiro: Lúmen Júris, 2007. p. 295 e ss.

${ }^{264}$ LORENZETTI, Ricardo Luis. Fundamentos do direito privado, p. 421

${ }^{265}$ Para estudo sobre a dignidade da pessoa humana, remetemos à HIRONAKA, Giselda Maria Fernandes Novaes. Responsabilidade pressuposta, p. 153 e ss, especialmente a p. 164; MORAES, Maria Celina Bodin de. A constitucionalização do direito civil e seus efeitos sobre a responsabilidade civil. In: SARMENTO, Daniel; SOUZA NETO, Cláudio Pereira de. A constitucionalização do Direito. Rio de Janeiro: Lúmen Júris, 2007. p. 436. 
comportamento estar certo e o outro errado, mas apenas de se escolher, entre duas condutas lícitas, qual é a mais importante. A questão é valorativa e de grau. Neste sentido, afirma Silvio Neves Baptista sobre a categoria em comento que:

\begin{abstract}
"O interesse predominante de um venha sobrepor-se ao interesse de outro, impondo a este o dever de 'suportar' a ofensa ou negando-lhe a faculdade de defesa quando do ataque do ofensor. Em contrapartida, o direito oferece ao prejudicado o poder de pleitear indenização pela ofensa tolerada, exigindo o dever de reparação da pessoa que viola o interesse de outro, embora o dano resulte de um fato permitido pelo ordenamento jurídico"266.
\end{abstract}

\title{
3.1.2.6 Dano permitido e desequilíbrio injusto
}

Para que haja a responsabilidade por conflito de direitos, é necessária também a ocorrência de, no pólo ativo, um dano permitido (também chamado dano lícito), que cause um desequilíbrio injusto ao pólo passivo.

Dano permitido é o prejuízo permitido pelo ordenamento jurídico à esfera de outrem. Dividem-se em danos permitidos suportáveis (ou não indenizáveis), considerados “ônus da vida em sociedade", e os danos permitidos insuportáveis (ou indenizáveis), como aqueles que apesar de se estar obrigado a suportar, deve-se reparação. Tem-se como exemplo dos primeiros, aquele que, no exercício de seu direito de propriedade, promove pequena festa em sua casa e seu vizinho é obrigado a suportar o barulho de bandas. Há dano, mas é suportável como mero ônus da vida em comum. Do segundo, que se está obrigado a suportar, mas que gera ao outro a obrigação de ressarcir, é que este trabalho trata como responsabilidade por conflito de direitos.

O conceito de dano permitido e seu par, dano injusto, são expressões de significados amplos, a ponto de Guido Alpa e Mario Bessone apresentarem-nas como uma cláusula geral que permite a interpretação mais flexível ${ }^{267}$.

266 BAPTISTA, Silvio Neves. Teoria geral do dano, p. 56.

267 ALPA, Guido; BESSONE, Mario. Elementi di diritto privato. 1. ed. Bari: Laterza, 2001. p. 412. 
Karl Larenz, com propriedade, afirma:

"aquele que tenha defendido seu interesse em prejuízo de direito de outro, ainda
que de forma autorizada, deverá indenizar ao prejudicado que teve de suportar a
perturbação de seu direito. Por esta razão, nestes casos, é sempre pressuposto que
um direito haja sido perturbado e que o titular do mesmo tenha de suportar
excepcionalmente esta perturbação" 268 .

Para caracterizar a responsabilidade por conflito de direitos, o dano permitido deve resultar num desequilíbrio injusto. Este juízo de eqüidade é aferido pelo legislador. Trata-se, em verdade, de uma conversão de direitos. A parte fica privada de exercer o seu direito em conflito com outro, porém, como compensação ao prejuízo sofrido, recebe uma indenização reparatória de sua situação ${ }^{269}$.

Sobre o desequilíbrio injusto é a lição de Karl Larenz:

“o interesse da pessoa cujo direito sofre o ataque ou transgressão, e ao que se antepõe o interesse da pessoa favorecida tem em consideração conceder-lhe uma pretensão de indenização mediante a qual se restabelece o justo equilíbrio entre ambos os interesses que se encontram em colisão" 270 .

Não se indeniza, por não haver desequilíbrio injusto, por exemplo, os danos ocorridos pela concorrência leal entre comerciantes.

\section{Nesse sentido, Sergio Cavalieri Filho ao afirmar que}

“o que está em causa é uma questão elementar de justiça comutativa, que se resume em saber quem é mais justo que suporte o dano, se o titular da coisa sacrificada ou do direito lesado, ou se aquele que se encontra em estado de necessidade, 271

Para fins da categoria em tela, o desequilíbrio resulta do conflito de direitos e da sobreposição de um deles.

${ }^{268}$ LARENZ, Karl. Derecho de obligaciones, § 72, p. 690. No original: "que aquel que ha defendido su interés en prejuicio del derecho de otro, aunque en forma autorizada, ha de indemnizar al prejudicado que hubo de soportar la perturbación de su derecho. Por lo tanto, en estos casos es siempre presupuesto que un derecho haya sido pertubado y que el titular del mismo haya de soportar excepcionalmente esa pertubación".

269 TRUJILLO, Elcio. Responsabilidade do estado por ato lícito, p. 106.

${ }^{270}$ LARENZ, Karl. Derecho de obligaciones, § 72, p. 691. No original: "El interés de la persona cuyo derecho sufre el ataque o transgresión y al que se antepone el interés de la persona favorecida se tiene en cuenta al concederle una pretensión de indemnización mediante la cual se restablece el justo equilibrio entre ambos intereses que se hallan entre sí en colisión".

271 CAVALIERI FILHO, Sérgio. Programa de responsabilidade civil, p. 552. 


\subsubsection{Reparação devida}

Por fim, para que se configure uma situação como hipótese de responsabilidade ex lege por conflito de direitos, é necessário que, após a ocorrência de todos os outros elementos, surja para o autor, por determinação legal, a obrigação de reparar o dano causado. Na lição de Silvio Neves Baptista, "Há responsabilidade pelo fato lícito danoso toda vez que a lei, ao mesmo tempo em que autoriza a violação do interesse de outrem, atribui ao prejudicado o poder de exigir indenização" 272 . Esta obrigação visa recompor, na medida do possível, a perda daquele que suportou dano.

A reparação devida decorre do juízo do legislador de que ao danificado não seria justo permanecer sem ressarcimento. Com vistas a se buscar a reparação do indivíduo na forma mais próxima possível de seu status quo ante, ou seja, antes da ocorrência do dano, a reparação deve ser feita, na medida do possível, in natura. No entanto, na maioria dos casos, por impossibilidade material, apenas será possível a reparação pecuniária do dano ocorrido.

Vale ressaltar que a reparação se baseará na existência do dano e será limitada pela existência e dimensão deste. Reparação pode ser integral ou proporcional ao desequilíbrio danoso, pois, em algumas circunstâncias, deve-se suportar, em certa medida, o dano ocorrido, tendo em vista a licitude do ato contrário (juízo de eqüidade).

Para o surgimento da reparação não é necessário provar cada um destes elementos. Eles apenas visam facilitar a visualização doutrinária da situação como responsabilidade civil ex lege por conflito de direitos.

272 BAPTISTA, Silvio Neves. Teoria geral do dano, p. 57. 


\subsection{EXCLUDENTES DA RESPONSABILIDADE}

A responsabilidade por conflito de direitos, como todo caso de responsabilidade civil, não é aplicada de plano a qualquer situação. Além da análise positiva, em que se verifica a concretização dos elementos do tripé conduta-nexo-dano, é necessário perquirir, também, sobre a presença, ou não, de elementos que excluem esta obrigação, o que força, necessariamente, a uma análise, também, negativa da obrigação.

Destarte, analisa-se a relação de duas formas: positivamente, buscando os elementos necessários para que ela se configure, e negativamente, demonstrando a inexistência de fatores excludentes de responsabilização, infirmando, assim, mais certeza na existência da obrigação reparatória. Os elementos que compõe esta fase negativa denominam-se: excludentes da responsabilidade civil.

Em síntese, pode-se afirmar que as hipóteses de exclusão da responsabilidade civil são situações, fatos ou eventos hábeis que fazem desaparecer ou transferir para terceiro a obrigação indenizatória que poderia resultar de um pretenso fato danoso, num primeiro momento, vinculada a alguém. Constituem, também, neste sentido, aspectos de defesa para aquele sobre o qual recai originalmente a obrigação.

Far-se-á, neste ponto, além da verificação dos elementos formais da configuração do seu suporte fático, também a análise de elementos mais circunstanciais e próprios de cada caso que, em algumas situações, podem excluir a necessidade de reparação do dano ocorrido.

As excludentes de responsabilidade reputam-se diretamente ligadas com os elementos que geram a responsabilização, porém, negativamente. Assim, elas podem se referir tanto à conduta do agente, ao nexo de causalidade como ao dano.

Em relação ao dano, a análise negativa fica prejudicada, pois que a questão resume-se sempre a sua existência ou não e sobre sua amplitude. Estas questões já foram resolvidas na análise positiva. ${ }^{273}$

Sobre o nexo, a questão invade os meandros que relacionam o dano ao ato, verificando-se a existência do liame e em que proporções ele ocorreu. São suas hipóteses

${ }^{273}$ Cf. Capítulo 3, item 1.1.1. 
de excludentes do nexo: o caso fortuito e a força maior, o ato de terceiro e o ato da própria vítima $^{274}$.

Quanto à conduta, uma divisão deve ocorrer, tendo em vista o fundamento da reparação. Caso trate-se de hipótese de responsabilidade subjetiva, em que o elemento ilícito é necessário, pode-se opor, para descaracterizar a obrigação reparatória, as excludentes de ilicitude do ato, tais como, o estado de necessidade e a legítima defesa e o exercício regular de direito ${ }^{275}$. No entanto, se as hipóteses em questão referem-se a casos de responsabilidade civil sem culpa, isto é, responsabilidade objetiva, as excludentes são as próprias da configuração do suporte fático da lei e não há como apresentar, como defesa, as excludentes de ilicitude.

Assim, nos casos de responsabilidade civil por conflito de direitos, como se trata de uma hipótese de responsabilidade objetiva, não é possível a oposição de excludentes de ilicitude para se eximir da obrigação reparatória, cabendo apenas a apresentação das excludentes de nexo, a saber, ato ou culpa da própria vítima, ato ou culpa de terceiro e as hipóteses de caso fortuito e força maior.

Pela importância do que foi expresso e pela imensa confusão que se faz quanto a esta questão, toma-se a liberdade de explicitá-la.

\subsubsection{Inoponibilidade das excludentes de ilicitude}

Às hipóteses de responsabilidade por conflito de direito não é possível se opor, como defesa, as excludentes que retiram a ilicitude do ato, para se eximir da obrigação reparatória.

As excludentes de ilicitude são aquelas situações que, em circunstâncias normais seriam ilícitas, porém, em virtude de um contexto todo especial, é permitido ao agente este ato, retirando dele toda a ilicitude. É o caso, por exemplo, da legítima defesa, em que ao

\footnotetext{
${ }^{274}$ CRUZ, Gisela Sampaio da. O problema do nexo causal na responsabilidade civil. Rio de Janeiro: Renovar, 2005. p. 155 e ss.

${ }^{275}$ Conforme preceitua o artigo 188 do Código Civil vigente.
} 
agente é permitido ferir alguém que o esteja agredindo ou na iminência de agredi-lo, desde que apenas para sua própria proteção.

Ora, em circunstâncias normais não é lícito a ninguém ferir qualquer pessoa, porém, em virtude deste contexto especial, permite-se a defesa imediata, pelo próprio indivíduo na iminência de ofensa. Serpa Lopes, como já apontado alhures, denominou este tipo de situação como "direito de prejudicar", em que a atividade é permitida, e o dano, na medida da importância e do necessário, também ${ }^{276}$.

Os casos de excludentes de ilicitude são, ao lado da legítima defesa, o estado de necessidade e o exercício regular de um direito.

Portanto, as excludentes de ilicitude retiram, como o próprio nome afirma, a ilicitude do ato, pois que não há, neste, qualquer erro de conduta, isto é, culpa.

Assim, pode-se inferir que a alegação das excludentes de ilicitude apenas tem lugar quando, para configuração da responsabilidade civil, seja necessário um ato ilícito. Desta forma, este tipo de excludente apenas cabe nas situações em que se invoca a reparação subjetiva baseada no artigo 186 do Código Civil.

No entanto, como já apontado, os casos de responsabilidade objetiva se baseiam em condutas permitidas pelo ordenamento jurídico, isto é, lícitas. Assim, não há que se invocar excludentes de ilicitude, pois que elas seriam inócuas para eximir o autor de qualquer responsabilização.

Esta simples assertiva de fácil compreensão constitui um dos erros mais comuns aos profissionais do direito quando se deparam com um caso que configure, no mais das vezes, estado de necessidade.

Para eximir-se da responsabilidade civil subjetiva, isto é, por conduta ilícitoculposa prevista no artigo 186, alega-se a excludente prevista no artigo 188 inciso II, isto é, posto que não constitui ato ilícito a "deterioração ou destruição da coisa alheia, ou a lesão a pessoa, a fim de remover perigo iminente".

${ }^{276}$ LOPES, Miguel Maria de Serpa. Curso de direito civil. 9. ed., v. I, § 387, p. 542. Cf. ainda SAVATIER, René. Traité de la responsabilité civile em droit français, p. 76. 
O defensor que arrazoou e provou os fatos neste sentido eximiu seu cliente de qualquer responsabilização baseada no artigo 186, pois provando a inexistência de culpa de seu cliente não há que se falar em responsabilidade subjetiva baseada em tal artigo. No entanto, este mesmo profissional confessou e provou a existência da responsabilidade objetiva por conflito de direitos entre o do seu cliente e o daquele que sofreu o dano, à qual está prevista reparação pelo artigo 929 do Código Civil ${ }^{277}$. É o ocorrido neste julgado, cujo relator foi o desembargador Humberto Theodoro Júnior ${ }^{278}$ :

\begin{abstract}
"O Estado de necessidade, como o do motorista que invade pista contrária para fugir de obstáculo em sua mão de direção e assim colide com veículo que transitava corretamente na outra pista, embora afaste o caráter ilícito da conduta do agente, não o exime, entretanto, do dever de reparar a lesão, desde que o dono do bem danificado não seja culpado pela situação perigosa (Código Civil, art. $159^{279}$ )".
\end{abstract}

A responsabilidade, por exemplo, no caso de estado de necessidade não surge pela ilicitude do ato, mas pela solução do legislador a um conflito entre direitos. Assim, em termos legais, este tipo de responsabilidade não surge pelo artigo 186 do Código Civil, pois está excluída a ilicitude pelo artigo 188, inciso II, mas surge, isto sim, pelo artigo 929 do mesmo código. $\mathrm{O}$ ato não entra no mundo do direito como ato ilícito, mas como ato-fato jurídico.

Para reafirmar esta ordem de idéias que é de fundamental importância, cita-se outro exemplo. O proprietário de prédio encravado, necessitando de passagem para a via pública, a faz, na medida do necessário, por um dos prédios vizinhos. O artigo 186 prevê que aquele que por ação voluntária violar direito ou causar prejuízo a outrem, fica obrigado a reparar o dano. Ora, o proprietário do prédio encravado teve atitude dolosa, violando direito de seu vizinho e, causando-lhe prejuízo, deve indenizar pelo artigo 186, pois que seu tipo está completo e mais, na forma mais grave, a daquele que causou dano voluntariamente, isto é, dolosamente.

277 Este tipo de comportamento do profissional do direito decorre da confusão que se faz entre a responsabilização civil e a penal. Na responsabilização penal, que visa à punição do culpado, e para tanto, avalia-se a conduta do agente, a alegação de estado de necessidade é suficiente para a prova de que seu ato é lícito, e como tal, não afronta o ordenamento jurídico, não podendo ser considerado crime. Contudo, o juízo cível, tendo em vista o reequilíbrio da situação alterada pelo dano, mesmo aceitando o julgamento penal, como é seu dever, e apesar de considerar lícito o comportamento do autor do dano, não pode deixar irressarcido aquele que teve seu direito prejudicado com o ato lícito do estado de necessidade. Assim, aplica-se à reparação, não pela ilicitude do ato que foi excluída pelo estado de necessidade, mas pela colisão de direitos prevista no artigo 929 do Código Civil.

${ }^{278}$ Extinto Tribunal de Alçada de Minas Gerais, Apelação Cível n. 20.869, originaria de Ouro Preto, relator Humberto Theodoro Júnior.

279 Referência feita ao Código Civil de 1916. 
O proprietário do prédio encravado, por sua vez, alega que agiu em exercício regular de direito seu, previsto no artigo 1.285 do Código Civil. Pelo artigo 188, inciso I, aquele que age desta forma não pratica ato ilícito e, portanto, sua conduta não está tipificada no artigo 186. Assim, a indenização subjetiva prevista neste artigo não ocorre.

Em que pese a atitude do proprietário do prédio encravado ser lícita, não é justo, ao que sofreu o dano, assim permanecer. Do conflito entre o necessário direito à passagem forçada reconhecido no artigo 1.285, e o direito de propriedade do vizinho danificado, o legislador dispôs que deve prevalecer, por sua importância, o direito de passagem forçada, mas ao proprietário prejudicado é devida reparação, prevista no artigo 1.285. Assim ocorre a indenização, por responsabilidade objetiva, baseada neste artigo.

Graficamente, esta situação pode ser apresentada da seguinte forma:

Quadro 3.1 Fundamento da indenização decorrente da criação de passagem forçada

\begin{tabular}{llll}
\hline Situação & Fundamento da reparação & Excludente & Resultado \\
\hline Passagem & subjetiva, violação de & exercício regular & Não gera \\
forçada & de direito (art. 186) & de direto (art. 188, I) & indenização \\
\hline $\begin{array}{l}\text { Passagem } \\
\text { forçada }\end{array}$ & objetiva, conflito & Não há & Gera \\
\hline
\end{tabular}

Fonte: elaborado pelo autor.

Dessa forma, pela licitude do ato já acolhida pelo ordenamento jurídico, não há de se falar em opor excludentes de ilicitude, como forma de exoneração de responsabilidade civil, se esta decorre do conflito de direitos.

\subsubsection{As excludentes de nexo}

Aos casos de responsabilidade por conflito de direitos, em virtude da permissão legal da conduta que a origina, apenas é possível opor as denominadas excludentes de nexo, para a exoneração da obrigação reparatória. 
Excludentes de nexo são aquelas que retiram a ligação existente entre a conduta do agente e o dano ocorrido, isto é, o nexo de causalidade entre o fato e o dano. Trata-se, dessa forma, de um problema de avaliação da extensão do nexo de causalidade no âmbito subjetivo, determinando-se quais os fatos que realmente ensejaram a ocorrência do dano.

Neste sentido, Eliseu Figueira, versando sobre as causas de isenção de responsabilidade para as hipóteses de responsabilidade objetiva, aponta: "Só provando-se a intervenção de factores estranhos, como o caso de força maior e, quanto a veículo, a imputabilidade do acidente ao próprio lesado ou a terceiro, é que o lesante fica exonerado de responsabilidade" 280 .

As hipóteses de excludentes de nexo são: a) o caso fortuito e a força maior; b) o ato ou culpa exclusiva da vítima; e c) o ato ou culpa exclusiva de terceiro.

No entanto, há que se ressaltar que, apesar de, em tese, adotar-se as hipóteses de excludentes de responsabilidade, apenas no estudo caso a caso das hipóteses é que se poderá aferir a possibilidade ou não desta defesa.

\subsubsection{Caso fortuito e força maior}

Os conceitos de caso fortuito e força maior são de conceituação controvertida ${ }^{281}$. Não há no Código Civil brasileiro preocupação clara em defini-los e diferenciá-los, restando aos estudiosos do Direito esta tarefa.

Em síntese, são as doutrinas que se contrapõem nesta tarefa: a subjetiva e a objetiva. A subjetiva, em acordo com a teoria da responsabilidade subjetiva, define, de forma negativa, caso fortuito e força maior como qualquer impossibilidade de cumprimento de dever jurídico por causa não-imputável ao devedor ${ }^{282}$.

\footnotetext{
${ }^{280}$ FIGUEIRA, Eliseu. Renovação do sistema de direito privado, p. 201.

281 MALUF, Carlos Alberto Dabus. Do caso fortuito e da força maior excludentes de culpabilidade no Código Civil de 2002. In: DELGADO, Mario Luiz; ALVES, Jones Figueiredo (Coord.). Questões controvertidas: responsabilidade civil. São Paulo: Método, 2006. v. 5, p. 42; PEREIRA, Caio Mário da Silva. Responsabilidade civil. § 244 p. 302 e ss.

282 MONTENEGRO, Antonio Lindenberg C. Responsabilidade civil, p. 318.
} 
Assim, para a doutrina subjetiva, à semelhança da análise dos casos de responsabilidade subjetiva, é necessário o exame da culpa do agente para verificar se ele é ou não responsável pelo dano. Caso o fato que motivou o dano seja efeito de fator alheio à vontade do agente, não há que se falar em indenização.

As diferenciações entre o caso fortuito e a força maior, para a doutrina, foram muitas e das mais variadas, porém, em sua maioria são concordes em afirmar haver sinonímia entre as duas expressões e que não há interesse prático em dar um significado especial a cada uma delas ${ }^{283}$.

A corrente objetiva, por seu turno, afirma, por vários critérios, a natureza do caso fortuito e da força maior, na tentativa de defini-los em si. É o que acena o parágrafo único do artigo 393 do Código Civil: "o caso fortuito e a força maior, verifica-se no fato necessário, cujos efeitos não era possível evitar ou impedir”. Tentou-se, dessa forma, mesmo que timidamente, definir objetiva e positivamente o caso fortuito e a força maior, porém sem diferenciá-los.

Em síntese, pode-se afirmar que são característicos do caso fortuito e da força maior os elementos da necessariedade e da inevitabilidade do fato ${ }^{284}$. Assim, qualquer fato que apresente estas características, por exemplo, um tufão, seria considerado caso fortuito ou força maior.

Nas palavras de Orlando Gomes, enquanto a doutrina objetiva define pela natureza dos acontecimentos, a doutrina subjetiva considera a ausência de culpa, independentemente de quaisquer dos elementos intrínsecos do acontecimento ${ }^{285}$.

Parece mais cientificamente acertada a definição objetiva por ser mais esclarecedora. Entretanto, como informa Roberto de Ruggiero, não é possível definir caso fortuito e força maior, como pretende a doutrina objetiva, pois estes são conceitos relativos e situacionais, isto é, dependem da situação em que estão insertos. São suas palavras:

\footnotetext{
"uma determinação positiva do casus supõe a existência de caracteres intrínsecos e objetivos do evento, reconhecíveis e absolutos, quando, em verdade, não

${ }^{283}$ Por todas cf. MALUF, Carlos Alberto Dabus. Do caso fortuito e da força maior excludentes de culpabilidade no Código Civil de 2002, p. 44 e MALUF, Carlos Alberto Dabus. Do caso fortuito e da força maior excludentes de culpabilidade. Revista do Advogado da Associação dos Advogados de São Paulo, n. 44, 1994, p. 28 e ss.

284 PEREIRA, Caio Mário da Silva. Responsabilidade civil, p. 304.

285 GOMES, Orlando. Obrigações. 16. ed., § 116, p. 175.
} 
possui, porquanto pode ser considerado fortuito numa relação jurídica e, como tal, não ser considerado em outra" ${ }^{, 286}$.

No entanto, a doutrina subjetiva sobre caso fortuito e força maior esbarra na impossibilidade de ser aplicada aos casos em que não há culpa a ser examinada, como é o da responsabilidade por conflito de direitos.

José de Aguiar Dias, por seu turno, oferece uma solução objetiva, um pouco mais genérica, porém mais precisa, quando afirma que a problemática do caso fortuito e da força maior é uma questão de análise do nexo de causalidade ${ }^{287}$.

Assim, para se afirmar se há ou não a presença de caso fortuito ou força maior, isto é, se existem elementos que descaracterizam a responsabilidade de determinada pessoa, é necessário se proceder a um exame do nexo entre os atos, fatos e os danos.

No mesmo sentido, Fernando de Sandy Lopes Pessoa Jorge afirma que caso fortuito e força maior não decorrem de um conceito da natureza, mas de um conceito normativo. A imprevisibilidade, assim, referir-se-ia ao curso anormal dos acontecimentos, e não se poderia falar em imprevisibilidade absoluta, mas apenas em uma verificação caso a caso das circunstâncias ${ }^{288}$.

Tudo se passa, desta forma, à análise do nexo de causalidade entre as condutas previstas na lei como geradoras de responsabilidade, e outras que não possuem esta previsão.

Em que pese ser a doutrina subjetiva a que atualmente prevalece, mormente nos casos de responsabilidade subjetiva, ela parece inócua para os casos de responsabilidade objetiva, como são os casos de responsabilidade por conflito de direitos. Busca-se, assim, manter sua aplicação no âmbito da responsabilidade subjetiva, porém urge procurar novos critérios de sua definição no âmbito da responsabilidade objetiva, talvez, retomando-se os conceitos objetivos de caso fortuito e força maior.

O inconveniente da concepção de José de Aguiar Dias para caso fortuito e força maior é que abrange inclusive o ato de terceiro e o ato da própria vítima. No entanto, resolver-se-ia a questão tomando caso fortuito e força maior apenas como atos

\footnotetext{
${ }^{286}$ RUGGIERO, Roberto de. Instituições de direito civil. 2. ed. Campinas: Bookseller, 2005. p. 172 e ss.

287 DIAS, José de Aguiar. Da responsabilidade civil, p. 687.

288 JORGE, Fernando de Sandy Lopes Pessoa. Ensaio sobre o pressuposto da responsabilidade civil. Lisboa: Centro de Estudos Fiscais, 1972. p. 126.
} 
relacionados à natureza (fatos jurídicos stricto sensu), os quais excluem a causalidade entre a conduta e o dano, deixando os atos humanos divididos em atos de terceiros e atos da própria vítima. À categoria em si, que abrange todas as hipóteses, restaria a denominação excludentes de nexo de causalidade ${ }^{289}$.

\title{
3.2.2.2 Ato da vítima
}

Nos dizeres de José de Aguiar Dias, por ato da vítima considera-se "o ato ou fato exclusivo da vítima, pela qual fica eliminada a causalidade em relação ao terceiro interveniente no ato danoso" ${ }^{290}$. O ato da vítima, desta forma, retira total ou parcialmente, a obrigação do primeiro indicado como responsável, por não haver nexo entre sua conduta e o dano.

Toma-se como exemplo, aplicável em responsabilidade objetiva por risco, o caso dado por Jorge Iturraspe em que

\begin{abstract}
"um automóvel circula por uma via e se não há culpa na condução está latente o risco criado pelo trânsito em si; ao sair de uma curva, uma pessoa em estado de ebriedade, sai detrás de uma árvore e se posta na passagem do veículo; particularmente quanto às lesões causadas, a circulação e o conseqüente risco ficam para trás, superado por um fato novo, de maior relevância. É o fato da própria vítima, o dano causado a si mesmo, o auto-dano"291.
\end{abstract}

Vê-se, assim, que mesmo em se tratando de responsabilidade objetiva, é possível opor a excludente do ato de terceiro.

A participação da vítima no evento danoso, porém, pode implicar apenas numa atenuação da responsabilidade do agente. É o que ocorre quando há uma concorrência de causas na consecução do dano. Tanto o ato do agente foi hábil para causar o dano, como o da vítima também o foi por sua causa ou majoração.

\footnotetext{
${ }^{289}$ Esta categoria estaria de acordo, também, com a denominada causa estranha, presente no artigo 1.382 do Código Civil francês.

${ }^{290}$ DIAS, José de Aguiar. Da responsabilidade civil, § 221, p. 693.

${ }^{291}$ ITTURRASPE, Jorge Mosset. Responsabilidad civil, p. 118. No original: "Un automóvil circula por una ruta y si bien no hay culpa en la conducción está latente el risgo creado por el hecho mismo del tránsito; al salir de una curva, una persona en estado de ebriedad, sale detrás de un árbol y se arroja al paso del vehículo; en la particular historia de las lesiones causadas, la circulación y el risgo consiguiente han quedado atrás, superados por un hecho nuevo, que les há quitado toda relevancia. Es el hecho de la propia víctima, el daño causado a sí mismo, o autodaño".
} 
É o que ocorre, por exemplo, no caso previsto no artigo 811, inciso I do Código de Processo Civil, de responsabilidade civil em virtude da concessão de medidas cautelares com posterior sentença reversa ${ }^{292}$. Em que pese este ser caso de responsabilidade por conflito entre direitos ${ }^{293}$, caso haja na produção do dano um ato hábil da própria vítima, deve-se proceder a uma equivalência das responsabilidades.

Assim, seja excluindo por completo ou apenas atenuando, o ato da própria vítima é um elemento estranho que abala a relação causal entre a conduta do responsável primário e o dano.

\subsubsection{Ato de terceiro}

A culpa de terceiro também se apresenta como excludente da responsabilidade daquele que se apresentou originalmente como responsável pelo fato.

Cumpre apontar que, tomando-se a responsabilidade como um todo situacional, há, neste caso, apenas uma transferência das pessoas envolvidas na situação e não o desaparecimento da responsabilização. A vítima não ficará irressarcida em virtude da comprovação de ato de terceiro, mas apenas que agora este terceiro é que deverá ser acionado para que cumpra sua obrigação. Trata-se, como se pode facilmente observar, de mais uma excludente de nexo de causalidade entre a conduta do responsável primitivo e o dano.

No entanto, em algumas situações especificamente tratadas em lei, para facilitar a posição da vítima que deveria ter de propor duas demandas até ver seu dano ressarcido, a lei estabelece que o responsável primitivo deva indenizar, guardando, porém, direito de regresso contra o terceiro que realmente causou o dano. É o caso, por exemplo, do estado de necessidade, expresso no artigo 930 do Código Civil. São também hipóteses de não

${ }^{292}$ Cf. ARMELIN, Donaldo. Responsabilidade objetiva no Código de Processo Civil. In: CRUZ E TUCCI, José Rogério (Coord.). Processo civil: estudo em comemoração aos 20 anos de vigência do Código de Processo Civil. São Paulo: Saraiva, 1995; FORNACIARI JÚNIOR, Clito. Dos prejuízos decorrentes da execução de medida cautelar. Revista Ajuris, n. 35, nov. 1985, p. 78; MOREIRA, José Carlos Barbosa. Responsabilidade do requerente de medida cautelar. Revista Ajuris, n. 27, mar. 1983, p. 109.

293 Segurança jurídica (CF/88, artigo 5, LIV) versus direito ao efetivo processo. Cf. ZAVASCKI, Teori Albino. Antecipação de tutela e colisão de direitos fundamentais, cit. 
exclusão expressa da responsabilidade, os casos previstos no artigo 932 do Código Civil ${ }^{294}$. Dessa forma, mesmo sendo o terceiro, em princípio, uma excludente de responsabilidade, pode ocorrer de a lei assim não o considerar.

Como ilustração, pode ser citado o caso daquele que entra em imóvel de vizinho para reparar imóvel seu. No caso de precisar de carriolas para retirada de entulho e estas danificarem parte do jardim, este dano estético-paisagístico deve ser indenizado plenamente, pois decorre diretamente da conduta do agente, cuja indenização está prevista no artigo 1.313 do Código Civil. Caso haja, no mesmo dia destes acontecimentos, um terceiro vizinho que, invejoso do jardim em questão, danifique ainda mais os canteiros, não há que se reclamar do vizinho que reforma sua casa a reparação destes novos danos, pois que decorrem de ato de terceiro. Caso, porém, os pedreiros contratados para a reforma, descuidadamente, caminharem sobre o jardim, responde o contratante por ato de terceiro seu preposto (artigo 923, inciso III), pagando também por estes danos.

${ }^{294}$ Art. 932. São também responsáveis pela reparação civil: I - os pais, pelos filhos menores que estiverem sob sua autoridade e em sua companhia; II - o tutor e o curador, pelos pupilos e curatelados, que se acharem nas mesmas condições; III - o empregador ou comitente, por seus empregados, serviçais e prepostos, no exercício do trabalho que lhes competir, ou em razão dele. IV - os donos de hotéis, hospedarias, casas ou estabelecimentos, onde se albergue por dinheiro, mesmo para fins de educação, pelos seus hóspedes, moradores e educandos; $\mathrm{V}$ - os que gratuitamente houverem participado nos produtos de crime, até a concorrente quantia. 


\section{HIPÓTESES DE APLICAÇÃO NO CÓDIGO CIVIL E NA LEGISLAÇÃO ESPECIAL}

Apresentados os pressupostos e a dinâmica do sistema da responsabilidade decorrente do conflito de direitos, faz-se necessário um ensaio de sua aplicação na prática jurídica. Para tanto, apresenta-se rol de hipóteses em que os índices que caracterizam esse instituto são mais evidentes, determinando assim, a viabilidade e utilidade da categoria em estudo.

Como reforço de argumentação, serão apresentadas algumas hipóteses em que, apesar de existirem pontos de similitude que poderiam gerar alguma confusão, não se devem considerar afetas à responsabilidade civil por conflito de direitos.

No entanto, é importante ressaltar que, independentemente das hipóteses aqui relacionadas, outras, esparsas pela legislação, são possíveis e prováveis, sempre que, no conflito entre dois direitos inconciliáveis, houver a necessidade prática de adjudicar a um o exercício do direito e outro, a possibilidade de obter justa indenização por ser preterido.

As hipóteses estão organizadas em quatro grandes categorias referentes aos danos causados em: estado de necessidade; limitações ao domínio baseadas no interesse social de coexistência pacífica de direitos individuais; limitações ao domínio em virtude do interesse social e exercício da tutela jurídica.

É necessário advertir que o capítulo não constitui um estudo exaustivo das hipóteses ou de suas peculiaridades, mas, sim, apenas verifica a sua existência e, especialmente, sua pertinência aos índices caracterizadores da responsabilidade civil ex lege por conflito de direitos. Assim, pede-se vênia pelos limites impostos à pesquisa e exposição dos assuntos, que, indubitavelmente, clamam por mais estudos. 
São os elementos específicos da responsabilidade civil por conflito de direitos, e, portanto, os índices caracterizadores de seu tipo: (a) ato do agente que causa dano praticado em exercício regular de um direito, isto é, um ato lícito; (b) há, primariamente, um conflito de direitos; (c) existência de inconciliação prática entre os direitos inicialmente em conflito; (d) há uma solução legislativa para a inconciliação prática dos direitos; (e) há, como solução, a sobreposição do direito considerado mais importante (f) há um dano permitido, mas, ao mesmo tempo, considerado injusto; e (g) há previsão de reparação ao ofendido.

\subsection{OBRIGAÇÃO DE COMPENSAR DANOS CAUSADOS EM ESTADO DE NECESSIDADE}

\subsubsection{Estado de necessidade como espécie (stricto sensu)}

Das hipóteses levantadas neste trabalho, a responsabilidade decorrente de atos praticados em estado de necessidade é, certamente, a de aceitação mais pacífica entre os doutrinadores $^{295}$, como caso de responsabilidade decorrente de um ato lícito cujo fundamento, portanto, não se confunde nem com a culpa nem com o risco. Em síntese, o estado de necessidade caracteriza-se como uma "situação de agressão a um direito alheio, de valor jurídico igual ou inferior àquele que se pretende proteger, para remover perigo iminente, quando as circunstâncias do fato não autorizarem outra forma de atuação"296.

Exemplos típicos de estado de necessidade são, no caso de proteção de terceiro (estado de necessidade altruísta), aquele que arromba a porta de casa de alguém para salvar a vida de uma pessoa em perigo, ou, no caso da proteção de bem próprio (estado de necessidade egoísta), aquele motorista que, para salvar sua vida de queda em desfiladeiro, atinge veiculo parado que impede a sua queda. O dano é autorizado pelo direito, visando

\footnotetext{
${ }^{295}$ Cf. LIMA, Alvino. Culpa e risco, p. 187; PEREIRA, Caio Mário da Silva. Responsabilidade civil, p. 296; MOTA PINTO, Carlos Alberto da. Teoria geral do direito civil, p. 122; MONTENEGRO, Antonio Lindebergh C. Responsabilidade civil, § 27, p. 38; GONÇALVES, Carlos Roberto. Responsabilidade civil, p. 25.

296 GAGLIANO, Pablo Stolze; PAMPLONA FILHO, Rodolfo. Novo curso de direito civil, v. III, p. 505.
} 
resguardar e proteger o bem maior, nos dois casos, a vida, em detrimento do bem material. No entanto, ao proprietário da casa ou do veículo estacionado, é garantida justa indenização dos prejuízos sofridos.

A presença do primeiro índice caracterizador da responsabilidade civil ex lege por conflito de direitos, qual seja, a licitude da conduta - que nada mais é que a exigência de que o ato do agente que causa dano seja praticado em conformidade com o ordenamento jurídico - está expressamente prevista no artigo 188 do Código Civil vigente, que afirma: "Não constituem atos ilícitos: (...) II - a deterioração ou destruição de coisa alheia, ou lesão a pessoa, a fim de remover perigo iminente".

Corrobora este sentido Alvino Lima, quando afirma tratarem-se as hipóteses previstas nos artigos 1.519 e 1.520 da responsabilidade decorrente de um ato lícito, no exercício de um direito ${ }^{297}$. Vários são os autores e estudos sobre os fundamentos da responsabilidade civil originária do estado de necessidade ${ }^{298}$.

Interessante ressaltar que o ato em estado de necessidade seria originalmente ilícito $^{299}$, uma vez que ofende direito alheio, mas, por força das circunstâncias, é garantida a ele a excludente de ilicitude, o que torna a atitude lícita. Estas circunstâncias são chamadas causas de justificação ou exclusão da ilicitude ${ }^{300}$.

Afasta-se por completo, nesta ordem de raciocínio, que o fundamento da responsabilidade decorrente do ato praticado em estado de necessidade, repouse na culpa $^{301}$. Não há o elemento subjetivo necessário à configuração da responsabilidade civil fundamentada na culpa. O que se verifica, na verdade, é o dano, objetivo a um bem, autorizado pelo ordenamento jurídico, em razão da especial circunstância em que a necessidade da natureza lhe impõe. Nesse sentido, afirma Silvio de Salvo Venosa:

"O indivíduo, na iminência de ver atingido direito seu, ofende direito alheio. O
ato, em sua essência, seria ilícito, mas a lei reconhece que há uma excludente. No
entanto, a escusabilidade do estado de necessidade sofre os temperamentos dos
arts. 929 (antigo art. 1.519) e 930 (antigo art. 1.520). O primeiro desses
dispositivos assegura a indenização ao dono da coisa ofendida, se não for
culpado pelo perigo, e o segundo dispositivo expressa que, se o perigo ocorrer

${ }^{297}$ LIMA, Alvino. Culpa e risco, p. 303. Referência feita aos artigos do Código Civil de 1916 transpostos aos artigos 929 e 930 do Código Civil vigente.

298 Por todos remetemos ao estudo feito por DIAS, José de Aguiar. Da responsabilidade civil, p. 674 e ss. e por LIMA, Alvino. Culpa e risco, p. 177.

299 HIRONAKA, Giselda Maria Fernandes Novaes. Direito civil: estudos. Belo Horizonte: Del Rey, 2000. p. 303.

300 HIRONAKA, Giselda Maria Fernandes Novaes. Direito civil, p. 303.

301 LIMA, Alvino. Culpa e risco, p. 187, 189 e 304. 
por culpa de terceiro, contra este deverá ser movida ação regressiva pelo autor do dano, para haver a importância que tiver ressarcido ao dono da coisa" ${ }^{\text {302 }}$.

Verificamos também, na hipótese, a presença do segundo e do terceiro índice caracterizador da responsabilidade civil por conflito de direitos, a existência inicial de conflito de direitos que, na prática, são inconciliáveis, uma vez que há de se adjudicar e decidir pela prevalência de um, considerado mais importante ${ }^{303}$.

Esta é a lição de Clóvis Beviláqua ao afirmar sobre o artigo 1.519 do Código Civil de $1916^{304}$ :

"O dispositivo supõe dois direitos em conflito, e declara que, se fôr absolutamente necessário, para a subsistência de um deles, o titular do mais valioso, do ponto de vista social, poderá sacrificar o outro, não excedendo os limites do indispensável. Todavia, aquêle que sofre o dano para o qual não concorreu, ao qual é estranho, merece que o indenizem do sacrifício, que lhe foi imposto. Parece irrecusável a equidade deste preceito",305.

Versando sobre o conceito específico do estado de necessidade, Caio Mário da Silva Pereira, assim nos conduz: "esboça-se nesta hipótese, um conflito de direitos ou de interesses. Um indivíduo, ante a perspectiva de lesão a um direito seu, ofende direito alheio. Na iminência de perigo a que vê exposta coisa sua, o agente causa dano a coisa alheia" ${ }^{306}$. Portanto, há necessariamente a sobreposição de um dos direitos, mais um índice caracterizador da responsabilidade civil por conflito de direitos.

No entanto, este dano, mesmo que autorizado pelo ordenamento, não pode ser considerado suportável, pela vítima. José de Aguiar Dias é enfático ao afirmar que "não há argumento capaz de convencer-nos de que o direito que temos de lesar a outrem em estado de necessidade, seja mais forte e mais merecedor de proteção do que o que assiste ao prejudicado de se ver reposto na situação anterior ao dano"307.

\footnotetext{
302 VENOSA, Silvio de Salvo. Direito civil: responsabilidade civil. 6. ed. São Paulo: Atlas, 2006. p. 52.

303 Posição contrária é a afirmada por PONTES DE MIRANDA; Francisco Cavalcanti. Tratado de direito privado, t. II, p. 346, que defende a inexistência de direito subjetivo ao estado de necessidade.

304 Correspondente, com alterações, ao artigo 929 do Código Civil vigente.

305 BEVILÁQUA, Clóvis. Código Civil dos Estados Unidos do Brasil comentado. 10. ed. São Paulo: Francisco Alves, 1957. v. V, p. 228.

306 PEREIRA, Caio Mário da Silva. Responsabilidade civil, p. 297. O exemplo apresentado pelo eminente doutrinador demonstra claramente a limitação vigente na época do Código Civil de 1916, em que apenas a lesão aos bens permitia a reparação decorrente de ato em estado de necessidade, o que não mais ocorre pela atual redação dos artigos 188, inciso II e 929 do Código Civil vigente.

307 DIAS, José de Aguiar. Da responsabilidade civil, p. 675.
} 
Assim, temos o dano permitido, mas que preconiza à vítima, indenização compensatória. Esta é a lição do português Carlos Alberto da Mota Pinto, ao versar sobre o artigo 339 do Código Civil Português 308 "A actividade do agente é secundum jus" e "apesar do carácter conforme o direito da actuação do sujeito, pareceu excessivo não dar à pessoa sacrificada uma reparação" 309 .

Sobre a aparente contradição entre a conduta lícita e sua indenização, já se discorreu no Capítulo 3, item 2.1, ao qual se faz referência por tratar-se de confusão a ser desfeita definitivamente para todas as categorias decorrentes da responsabilidade civil por conflito de direitos.

Como bem nos alerta Carlos Roberto Gonçalves, mesmo não considerada ilícita a conduta daquele que age em estado de necessidade, exige-se que repare o prejuízo causado ao dono da coisa, se este não for culpado pelo perigo ${ }^{310}$. Aqui, identifica-se que o dano causado, apesar de permitido, é considerado injusto de ser suportado pela vítima.

Daí decorre o último índice caracterizador da responsabilidade por conflito de direitos, qual seja a solução legislativa.

Assim fez o legislador ao prever compensação do dano causado em estado de necessidade no artigo 929 quando dispõe: "Se a pessoa lesada, ou dono da coisa, no caso do inciso II do artigo 188, não forem culpados do perigo, assistir-lhes-á direito a indenização do prejuízo que sofreram”.

No mesmo sentido é a lição de Giselda Maria Fernandes Novaes Hironaka ao ponderar "com certeza não poderia haver lugar a idéia de se deixar irressarcida a vítima inocente do dano produzido sob a especial circunstância do estado de necessidade, exatamente para afastar um perigo iminente" 311.

\footnotetext{
${ }^{308}$ Art. 339 do Código Civil Português: 1. É licita a acção daquele que destruir ou danificar coisa alheia com o fim de remover o perigo actual de um dano manifestamente superior, quer do agente, quer de terceiro. 2. o autor da destruição ou do dano é, todavia, obrigado a indemnizar o lesado pelo prejuízo, se o perigo for provocado por sua culpa exclusiva; em qualquer outro caso, o tribunal pode fixar uma indemnização eqüitativa e condenar nela não só o agente, como aqueles que tiraram proveito do acto ou contribuíram para o estado de necessidade.

${ }^{309}$ MOTA PINTO, Carlos Alberto da. Teoria geral do direito civil, p. 122.

310 GONÇALVES, Carlos Roberto. Responsabilidade civil, p. 503.

311 HIRONAKA, Giselda Maria Fernandes Novaes. Direito civil: estudos. Belo Horizonte: Del Rey, 2000. p. 310.
} 
Ressalta-se que o fundamento em questão, da responsabilidade civil do ato em estado de necessidade, não se confunde com o fundamento da responsabilidade civil objetiva fundada no risco. Primeiro, porque a situação de perigo ataca aquele que age em estado de necessidade, ou seja, o agente sofre o perigo e reage, daí seu ato ocorrer em estado de necessidade. Entretanto, na hipótese de responsabilização pelo risco do artigo 927, os papéis são exatamente contrários e o causador do perigo é o agente e o paciente da atividade perigosa é a vítima (ou lesado). Segundo, na responsabilidade civil por ato em estado de necessidade não há risco de dano ao lesado, mas efetivamente o dano causado pelo agente.

Assim, concluímos com Aparecida Amarante que conceituando o estado de necessidade, sintetiza os índices caracterizadores da responsabilidade civil por conflito de direitos ao afirmar: "Ocorre por vezes, um conflito entre o direito/interesse de um indivíduo com o de outro. Dada a impossibilidade de co-existência, um deles deve sucumbir, com o desaparecimento ou cessação transitória que, por princípio de equidade, será o menos valioso, não necessariamente do ponto de vista econômico, mas do ponto de vista ético e humano. Autoriza-se a violação do direito alheio, com o fim único de evitar um mal maior" ${ }^{312}$ e completamos, nesta situação o legislador, por juízo de eqüidade, previu ser devida ao lesado justa indenização dos danos suportados.

\subsubsection{Legítima defesa real e putativa}

No que se refere às relações envolvendo atos praticados em legítima defesa, que originam a obrigação de indenizar, verifica-se que podem causar confusão quanto ao fundamento da obrigação indenizatória, mas que, nenhum deles se confunde com a responsabilidade civil por conflito de direitos. A seguir, são analisadas situações assemelhadas para, ao final, verificar a impertinência dos índices caracterizadores da responsabilidade civil por conflito de direitos à hipótese em estudo.

Primeiro, tratemos da legítima defesa real. Esta, de acordo com o ordenamento jurídico brasileiro, não é fonte da obrigação reparatória, pois que há apenas defesa à

312 AMARANTE, Aparecida. Excludentes de ilicitude civil, p. 122. 
agressão feita contra si ou terceiro, no estrito limiar necessário para repelir o perigo. A legítima defesa é reação ao ato e justificativa para a conduta do agressor.

O estatuto civil toma emprestado o conceito do Direito Penal, como alerta Giselda Maria Fernandes Novaes Hironaka ${ }^{313}$. Assim, o conceito decorre do Direito Penal, que nos auxilia a compreender seus limites, quais sejam: a iniciativa da agressão advinda de outrem, a ausência de provocação da vítima que legitimamente se defende, a ameaça atual ou iminente, a reação equivalente à agressão ${ }^{314}$.

Há o interesse que todo indivíduo tem (de justiça, segurança e ordem), de que não seja violado em seu prejuízo. Desse modo, o regime jurídico confere a todo indivíduo direito de intervir, violar, dentro de certos limites, o domínio garantido a outrem, quando ele próprio é vítima de uma agressão injusta por parte deste último (legítima defesa) ${ }^{315}$.

Sobre o conceito da legitima defesa Silvio de Salvo Venosa acresce

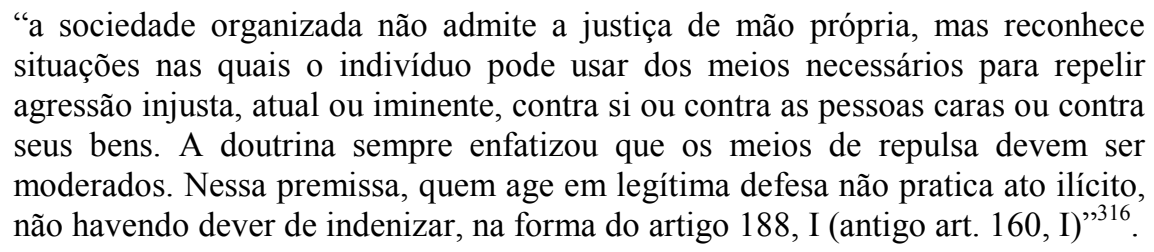

Assim, verifica-se a licitude do ato e a desnecessidade de indenização de eventuais prejuízos sofridos por aquele que causou dano, uma vez que, na legítima defesa real, o causador da atitude do agressor foi a própria vítima, cumprindo ao agressor apenas reagir, proporcionalmente, à injusta agressão, atual ou iminente.

A indenização devida, em razão de eventual excesso ocorrido na prática do ato em legítima defesa real, será tratada como ato ilícito e se submeterá à disciplina da responsabilidade subjetiva, em razão da culpa inerente ao ato ${ }^{317}$.

Da mesma forma, a legítima defesa putativa, não se enquadra como hipótese de responsabilidade civil por conflito de direitos, pois trata-se de ato ilícito.

313 HIRONAKA, Giselda Maria Fernandes Novaes. Direito civil, p. 305. No mesmo sentido PEREIRA, Caio Mário da Silva. Responsabilidade civil, p. 295.

314 HIRONAKA, Giselda Maria Fernandes Novaes. Direito civil, p. 305.

315 AMARANTE, Aparecida. Excludentes de ilicitude civil, p. 20.

316 VENOSA, Silvio de Salvo. Direito civil: responsabilidade civil, p. 50.

317 PONTES DE MIRANDA, Francisco Cavalcanti. Tratado de direito privado, $\S 184$, p. 333 e GAGLIANO, Pablo Stolze; PAMPLONA FILHO, Rodolfo. Novo curso de direito civil, v. III, p. 115. 
Neste sentido, deve ser mencionada a afirmação de Carlos Roberto Gonçalves:

\begin{abstract}
"embora com denominação semelhante, a legítima defesa putativa nada tem em comum com a legítima defesa real, não podendo ser aceitas como situações idênticas. Na primeira, a conduta é lícita, eis que objetiva afastar uma agressão real contra a vítima ou um terceiro. Há efetiva reação do ofendido contra ato de um agressor. Diverso é o que ocorre na legítima defesa putativa, fundamentada em erro, não existindo agressão alguma, mas apenas equívoco do pseudoagredido. Logo, sua conduta é ilícita, penalmente irrelevante, eis que ausente o dolo, mas ingressa na ampla órbita do ilícito civil, ensejando indenização"318.
\end{abstract}

Este também, o julgamento do Recurso Especial 47.246/RJ; cujo relator foi o Ministro Costa Leite ao dispor:

\begin{abstract}
"Civil. Indenização. Homicídio. Pensão. Dano moral. Julgamento extra petita. A suspensão do processo, na hipótese de que trata o art. 110, do CPC, e facultativa, estando entregue ao prudente exame do juiz, em cada caso, que deve ter uma linha de conta a possibilidade de decisões contraditórias. Impossibilidade de decisões contraditórias na espécie vertente. Ainda que admitida a tese de legítima defesa putativa, subsistiria a obrigação de reparar o dano, visto não ser caso de exclusão de ilicitude"
\end{abstract}

Assim, a legítima defesa real não gera indenização ao que repele com os meios necessários a uma agressão injusta. Não há previsão no Código Civil de que este dano deva ser reparado, ao contrário, ele é afirmado como excludente de responsabilidade civil, no artigo 188, inciso I. Esta é a posição de Clóvis Beviláqua em comentário sobre o artigo 1.520 do Código Civil de $1916^{319}$ : "No caso de legítima defesa, em regra, não há dano a ressarcir. $\mathrm{O}$ agredido repele o agressor, o possuidor repele os atos do esbulho; se não praticou excesso, nada tem que indenizar" ${ }^{320}$.

No entanto, há responsabilidade civil em casos que envolvam legítima defesa, quando ela for excessiva e putativa ${ }^{321}$, casos em que o ato é ilícito e que não se confundem com a legítima defesa real ${ }^{322}$. Dessa forma, nenhum desses casos poderá ser considerado hipótese de responsabilidade civil ex lege por conflito de direitos.

\footnotetext{
${ }^{318}$ GONÇALVES, Carlos Roberto. Responsabilidade civil, p. 504. No mesmo sentido, cf. LENZ, Luis Alberto Thompson Flores. A responsabilidade civil frente à legítima defesa putativa. Revista dos Tribunais, São Paulo, n. 632, jun. 1998. p. 67 e ss.

319 Correspondente, com alterações, ao artigo 930 do Código Civil vigente.

${ }^{320}$ BEVILÁQUA, Clóvis. Código Civil dos Estados Unidos do Brasil comentado, v. V, p. 229.

${ }^{321}$ A legítima defesa putativa exclui a culpa no Código Penal, porém não exclui a indenização pelo artigo 186 do Código Civil, pois que o conceito de culpa no Civil no Penal é diferenciado.

${ }^{322}$ LENZ, Luis Alberto Thompson Flores. A responsabilidade civil frente à legítima defesa putativa, Revista dos Tribunais, São Paulo, n. 632, jun. 1998, p. 67e ss.
} 


\subsection{OBRIGAÇÃO DE COMPENSAR DANOS RESULTANTES DE LIMITAÇÕES AO DOMÍNIO BASEADAS NO INTERESSE SOCIAL DE COEXISTÊNCIA PACÍFICA DE DIREITOS INDIVIDUAIS}

Há hipóteses da responsabilidade por conflito de direitos nas limitações de domínio baseadas no interesse social de coexistência pacífica de direitos individuais. Conforme já apontado, o exercício dos direitos, especialmente os relacionados à propriedade, não são absolutos ${ }^{323}$. É necessário considerar os direitos do proprietário e seu vizinho face às limitações legais ${ }^{324}$.

Os limites civis estabelecidos pelos direitos de vizinhança ao exercício do direito de propriedade demonstram a evolução e a aplicação do princípio da socialidade, base do Código Civil vigente ${ }^{325}$, e princípio inspirador da responsabilidade civil por conflito de direitos $^{326}$. Assim, não se tratam de interesses individuais, mas públicos ${ }^{327}$, de que as partes coexistam pacificamente ${ }^{328}$.

A questão referente à responsabilidade civil que se estabelece entre os vizinhos de prédios tem sido por demais debatida e acompanhada de flexibilizações do conceito de culpa, visando oferecer a solução justa aos casos que se apresentam. Todavia, Alvino Lima, sustenta não haver controvérsias de que a responsabilidade decorrente dos danos originários de relações de vizinhança não podem se restringir aos princípios da responsabilidade extracontratual fundada na culpa. ${ }^{329}$

${ }^{323}$ COMPARATO, Fabio Konder. Direitos e deveres fundamentais em matéria de propriedade. Disponível em: $<$ http://www.cjf.gov.br/revista/numero3/artigo11.htm>. Acesso em: 02 jan. 2007.

${ }^{324}$ DANTAS, Francisco Clementino San Tiago. Programa de direito civil. Rio de Janeiro: Editora Rio, 1979. v. III, p. 249.

${ }^{325}$ LISBOA, Roberto Senise. Manual de direito civil. 3. ed. São Paulo: RT, 2005. v. 4, p. 261.

${ }^{326}$ Cf. Capítulo 1, item 2.

327 Neste sentido o julgamento no Superior Tribunal de Justiça do Recurso Especial n. 316.336/MS cujo relator foi o Ministro Ari Pargendler, em 18/08/2005: Civil. "Direitos de Vizinhança. Passagem Forçada (CC, Art. 559). Imóvel Encravado. Numa era em que a técnica da engenharia dominou a natureza, a noção de imóvel encravado já não existe em termos absolutos e deve ser inspirada pela motivação do instituto da passagem forçada, que deita raízes na supremacia do interesse público; juridicamente, encravado é o imóvel cujo acesso por meios terrestres exige do respectivo proprietário despesas excessivas para que cumpra a função social sem inutilizar o terreno do vizinho, que em qualquer caso será indenizado pela só limitação do domínio. Recurso especial conhecido e provido em parte"

328 GOMES, Orlando. Direitos reais. 19. ed. Rio de Janeiro: Forense, 2007. p. 215.

329 Por todos remetemos ao estudo de LIMA, Alvino. Culpa e risco, p. 90, 167 e ss. 
Alvino Lima, inicialmente, visando dissipar dúvidas sobre a questão diferencia claramente duas situações: " $1^{\circ}$ os danos resultantes do exercício do direito de propriedade perturbando os vizinhos e lesando os seus direitos, quando o proprietário agiu com dolo ou

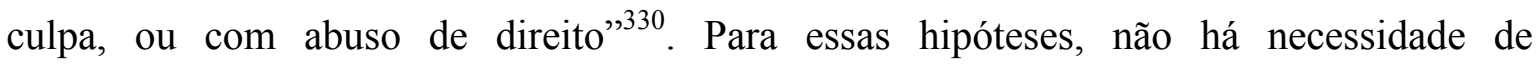
sistematização diferenciada, pois que serão solucionadas pelo sistema da responsabilização subjetiva, fundamentada na conduta ilícita.

A segunda hipótese, por seu turno, refere-se aos "danos resultantes das perturbações normais, excedendo os inconvenientes ordinários de vizinhança, embora sem a existência da culpa" ${ }^{\text {331 }}$. O princípio é o de que os vizinhos não são obrigados a suportar, sem a devida indenização, os inconvenientes que excedam à medida ordinária das obrigações de vizinhança ${ }^{332}$.

Nestes casos, em que não há o erro de conduta ou abuso de direito, que caracterizariam a responsabilidade subjetiva, podem ser encontradas algumas hipóteses de responsabilidade por conflito de direitos.

Sobre formas de indenização ao proprietário prejudicado com fundamento diverso da culpa, é a lição de Orlando Gomes ${ }^{333}$ :

"O proprietário é obrigado, a sofrer limitações no conteúdo do seu direito, por
exigências do interesse público ou do interesse social de coexistência pacífica
dos direitos individuais, e justo não seria que se lhe negasse uma compensação.
A lei a confere-a sob a forma de indenização. Nestes casos, porém, o dever de
indenizar, imposto a quem a limitação aproveita, não é conseqüência de violação
do direito, pois é lícito o ato de que resulta a turbação" 334 .

No trecho acima, verificamos a presença da licitude do ato praticado, o que caracteriza a responsabilidade por conflito de direitos.

\footnotetext{
${ }^{330}$ LIMA, Alvino. Culpa e risco, p. 90, 169.

331 LIMA, Alvino. Culpa e risco, p. 90, 169.

332 LIMA, Alvino. Culpa e risco, p. 173.

333 Interessante notar a posição do citado autor (GOMES, Orlando. Direitos reais, p. 219) pela desnecessidade de preocupação doutrinária com tais hipóteses, pois que plenamente solucionadas pelo comando legal. São suas palavras "O problema do fundamento da responsabilidade do proprietário que causa prejuízo ou incômodo ao vizinho interessa aos sistemas legislativos que não contém preceito em que esteja firmada de modo inequívoco. Entre nós, a pesquisa deste fundamento torna-se desnecessária em face da existência de artigo de lei no qual a responsabilidade pelos danos causados aos vizinhos está claramente definida”.

334 GOMES, Orlando. Direitos reais, p. 296.
} 
Tais hipóteses são as denominadas por Francisco Clementino San Tiago Dantas como “direitos de vizinhança onerosos?". Para o citado autor estes são direitos cuja obtenção demanda pagamento de indenização, pois que só são reconhecidos com a compensação ao vizinho do prejuízos que decorre do dever assumido ${ }^{335}$.

Assim, constata-se a existência de direito subjetivo de vizinhança como limitador do exercício do direito de propriedade, que, conforme o caso será um direito de fazer algo no prédio contíguo, ou direito a uma abstenção por parte do proprietário vizinho, ou direito a uma prestação positiva ${ }^{336}$. Desta limitação, surge, em alguns casos, como solução justa a este conflito, a obrigação de indenizar ao prejudicado. Esta indenização poderá ser necessária, como requisito para o exercício do direito de vizinhança, ou eventual, casos em que, embora o exercício do direito seja gratuito, ele gera danos ao proprietário do prédio vizinho ${ }^{337}$.

Verificamos as hipóteses de responsabilidade por conflito de direitos nos casos de passagem forçada, uso do prédio confinante na servidão de aqueduto, na águas artificiais colhidas pelo prédio inferior e pela elevação artificial das águas.

\subsubsection{Passagem forçada}

A indenização cabal devida àquele que suporta a criação da passagem forçada apresenta-se como categoria apta a integrar o rol de hipóteses de responsabilidade civil por conflito de direitos.

A título de noção, a passagem forçada trata de direito do proprietário do prédio encravado, seja ele urbano ou rural, que necessita de saída para a via pública. A este direito não se pode opor o vizinho. A passagem deve ser fixada no caminho mais curto, no prédio mais próximo e de forma menos onerosa para ambas as partes. A esse propósito, dispõe o

\footnotetext{
335 DANTAS, Francisco Clementino San Tiago. Programa de direito civil, p. 252.

${ }^{336}$ DANTAS, Francisco Clementino San Tiago. O conflito de vizinhança e a sua composição, p. 269- 271.

337 GOMES, Orlando. Direitos reais, p. 219.
} 
vigente Código que "sofrerá o constrangimento o vizinho cujo imóvel mais natural e facilmente se prestar à passagem" (artigo $\left.1.285, \S 1^{\circ}\right)^{338}$.

Para ter direito à passagem forçada, é necessário o denominado encravamento do imóvel. O prédio que não possua saída para a via pública, nascente ou porto é considerado prédio encravado para fins de determinação da necessidade da passagem forçada. Como nos alerta Caio Mário da Silva Pereira, "não bastam razões de comodidade, nem o vizinho tem de suportar o encargo da passagem para melhoria das condições de acesso àquelas serventias. Assim, pois, se o prédio for dotado de saída, por muito má que seja, não se qualifica como encravado, 339 .

No entanto, é requisito para o exercício do direito à passagem forçada, o pagamento de indenização cabal, conforme disposição expressa no artigo 1.285 do Código Civil que versa:

Art. 1.285 . O dono do prédio que não tiver acesso a via pública, nascente ou
porto, pode, mediante pagamento de indenização cabal, constranger o vizinho
a lhe dar passagem, cujo rumo será judicialmente fixado, se necessário. $\S 1^{\circ}$
Sofrerá o constrangimento o vizinho cujo imóvel mais natural e facilmente se
prestar à passagem. $\S 2^{\circ}$ Se ocorrer alienação parcial do prédio, de modo que
uma das partes perca o acesso a via pública, nascente ou porto, o proprietário
da outra deve tolerar a passagem. $\S 3^{\circ}$ Aplica-se o disposto no parágrafo
antecedente ainda quando, antes da alienação, existia passagem através de
imóvel vizinho, não estando o proprietário deste constrangido, depois, a dar
uma outra.

Assim, pode-se verificar, a presença dos índices caracterizadores da responsabilidade por conflito de direitos.

A instituição da passagem forçada é ato em conformidade com o direito e, portanto, lícito. Dessa forma, atendidos os pressupostos do artigo 1.285, o agente está legitimado a solicitar o exercício do direito à passagem forçada.

Carlos Roberto Gonçalves ${ }^{340}$ apresenta-a como exemplo de "responsabilidade extracontratual decorrente de fatos permitidos por lei". No mesmo sentido, Pablo Stolze e Rodolfo Pamplona, admitem expressamente a hipótese como atos lícitos que poderão impor a obrigação de indenizar, e complementam: "a obrigação de indenizar decorre de um

\footnotetext{
338 VENOSA, Silvio de Salvo. Direito civil: direitos reais. 6. ed. São Paulo: Atlas, 2006. p. 266.

339 PEREIRA, Caio Mário da Silva. Instituições de direito civil, v. 4, p. 216 e 217.

340 Responsabilidade civil, p. 29.
} 
ato perfeitamente lícito: o próprio direito de passagem, previsto no referido artigo de lei",341.

Há, primordialmente, um conflito de direitos no caso, contrapondo-se o direito a acesso à via pública, que dá destinação econômica ao imóvel, contra o direito de propriedade regularmente estabelecido do prédio que suportará a passagem forçada. Como nos informa Silvio de Salvo Venosa: "mais importante é a saída para a via pública. A fonte ou porto dependerá da utilização econômica da propriedade. O vizinho deve suportar a passagem"342.

A limitação do direito é clara na lição de Francisco Cavalcanti Pontes de Miranda:

\footnotetext{
“A passagem forçada, de que se fala nos arts. $559-562^{343}$ do Código Civil, não é a servidão de passagem, mas limitação ao conteúdo do direito de propriedade. É o caminho necessário, que não mais consiste em direito à constituição ou estabelecimento de servidão"344.
}

Há que se reparar o dano, que apesar de autorizado, não deve ser suportado pelo danificado com o seu exercício. Neste sentido, Caio Mário da Silva Pereira afirma que "a passagem forçada não constitui, todavia, um ônus gratuito: o proprietário do prédio por onde se estabelece tem direito a indenização cabal"345.

A indenização compensatória de restrição lícita ao conteúdo do direito de propriedade é estatuída geralmente como fórmula de composição dos conflitos de vizinhança, como acontece, por exemplo, com a passagem forçada. O proprietário obrigado a concedê-la faz jus à indenização ${ }^{346}$.

Interessante notar que os pontos de similitude entre a passagem forçada e a desapropriação são consideráveis a ponto de autores considerarem a passagem forçada como "uma desapropriação no interesse particular" ${ }^{347}$. Na linha de raciocínio deste estudo, tais similitudes podem ser explicadas pelos elementos comuns à responsabilidade por

\footnotetext{
${ }^{341}$ GAGLIANO, Pablo Stolze; PAMPLONA FILHO, Rodolfo. Novo curso de direito civil. v. III, p. 505-506.

342 VENOSA, Silvio de Salvo. Direito civil: direitos reais, p. 286.

343 Referência ao Código Civil de 1916 hoje correspondentes ao artigo 1.285 do Código Civil vigente.

344 PONTES DE MIRANDA, Francisco Cavalcanti. Tratado de direito privado. Campinas: Bookseller, 2001. t. XIII, p. 406.

345 PEREIRA, Caio Mário da Silva. Instituições de direito civil, p. 216.

346 GOMES, Orlando. Direitos reais, p. 297.

${ }^{347}$ Cf. DANTAS, Francisco Clementino San Tiago. O conflito de vizinhança e a sua composição. Rio de Janeiro, 1939. p. 305, GONÇALVES, Carlos Roberto. Direito civil brasileiro. São Paulo: Saraiva, 2006. v. V, p. 335; DINIZ, Maria Helena. Curso de direito civil brasileiro. 21. ed. São Paulo: Saraiva, 2006. v. 4, p. 283.
} 
conflito de direitos, porém, ressalva-se, os institutos são diversos e possuem, cada um, suas características e princípios reguladores próprios.

Nesse sentido, a afirmação de Caio Mário da Silva Pereira:

\begin{abstract}
"Não é sem motivo que os autores costumam qualificar a instituição da passagem forçada como uma espécie de desapropriação, que se não realiza por necessidade pública, mas cumpre-se por interesse particular, não lhe faltando a categoria de "utilidade pública indireta", como considerava Teixeira de Freitas (Consolidação das leis Civis, art. 66 - nota de rodapé), tendo em vista que, ao menos mediatamente, há um benefício para a coletividade, ${ }^{348}$.
\end{abstract}

Pelo exposto conclui-se pela pertinência da indenização cabal devida no caso de passagem forçada como hipótese de responsabilidade civil por conflito de direitos.

\title{
4.2.2 Uso do prédio confinante
}

Outra hipótese que julga-se pertinente à categoria da responsabilidade decorrente de conflito de direitos refere-se à obrigação indenizatória do proprietário que necessita usar o prédio vizinho para reparação ou limpeza. Nesta situação, nos dizeres de Silvio Rodrigues, "um proprietário para proceder à reparação ou limpeza, construção ou reconstrução de sua casa ou dos esgotos, goteiras, aparelhos higiênicos, poços ou fontes nela existentes, [precisa] ingressar na casa do vizinho",349.

A hipótese está expressamente prevista no artigo 1.313 do Código Civil, em especial no $\S 3^{\circ}$, transcrito a seguir:

\footnotetext{
"Artigo 1.313. O proprietário ou ocupante do imóvel é obrigado a tolerar que o vizinho entre no prédio, mediante prévio aviso, para: I - dele temporariamente usar, quando indispensável à reparação, construção, reconstrução ou limpeza de sua casa ou do muro divisório; II - apoderar-se de coisas suas, inclusive animais que aí se encontrem casualmente. $\S 1^{\circ} \mathrm{O}$ disposto neste artigo aplica-se aos casos de limpeza ou reparação de esgotos, goteiras, aparelhos higiênicos, poços e nascentes e ao aparo de cerca viva. $\S 2^{\circ} \mathrm{Na}$ hipótese do inciso II, uma vez entregues as coisas buscadas pelo vizinho, poderá ser impedida a sua entrada no imóvel. $\S 3^{\circ} \mathrm{Se}$ do exercício do direito assegurado neste artigo provier dano, terá o prejudicado direito a ressarcimento".
}

\footnotetext{
348 PEREIRA, Caio Mário da Silva. Instituições de direito civil. Rio de Janeiro: Forense, 2004. v. 4, p. 216.

349 RODRIGUES, Silvio. Direito civil. Direito das coisas, p. 165 e ss.
} 
Neste caso, há a atribuição, ao proprietário de prédio confinante, de direito de usar o prédio vizinho, nos estritos limites necessários para reparar, construir ou limpar seu muro ou prédio, bem como alcançar coisas suas que estejam no prédio vizinho.

Esta é a lição de Orlando Gomes ao afirmar: "quando necessário, o dono de um prédio pode entrar no do vizinho para decotar a cerca viva ou reparar o muro divisório, mediante aviso prévio. Obrigado estará, porém, a indenizar o dano que cause. A indenização é, portanto, eventual”350.

A atitude de quem usa o prédio confinante com a finalidade legal é, portanto, lícita. Eventual abuso ou excesso será punido com a responsabilização subjetiva decorrente de sua culpa. Verificamos aqui importante índice caracterizador da responsabilidade civil por conflito de direitos.

A licitude da conduta é, mais uma vez, reafirmada por Carlos Roberto Gonçalves $^{351}$ quando apresenta a categoria em estudo como exemplo de responsabilidade extracontratual decorrente de fatos permitidos por lei. No mesmo sentido, Pablo Stolze e Rodolfo Pamplona, ao apresentarem-na como exemplo de obrigação de indenizar em decorrência de ato lícito ${ }^{352}$.

Verifica-se ainda um conflito de direitos entre o exercício do direito de propriedade e a restrição imposta pelo direito de usar a propriedade alheia. A restrição se justifica, na lição de Hely Lopes Meirelles, em razão

\footnotetext{
"do dever recíproco de vizinhança e pelas vantagens que dela decorrem para o vizinho que a suporta, pois que a conservação e a limpeza das construções e de seus tapumes são benéficas à segurança dos prédios e à saúde dos vizinhos. Além do mais, essa entrada no prédio vizinho não é feita arbitrariamente: está condicionada à necessidade das construções, reparações ou limpezas ${ }^{333}$,
}

A inconciliação dos direitos decorre da hipótese em que mesmo que no exercício legítimo da atividade e dentro dos estritos limites do necessário, seja causado dano.

Ocorre que, no caso, há o que Francisco Clementino San Tiago Dantas denomina “dever de tolerância"354, por parte do vizinho, devendo o proprietário consentir que outros interfiram em sua esfera jurídica, realizando atos que ele estava em condições de repelir.

\footnotetext{
${ }^{350}$ GOMES, Orlando. Direitos reais, p. 297.

351 GONÇALVES, Carlos Roberto. Responsabilidade civil, p. 29.

352 GAGLIANO, Pablo Stolze; PAMPLONA FILHO, Rodolfo. Novo curso de direito civil, v. III, p. 506.

${ }^{353}$ MEIRELLES, Hely Lopes. Direito de construir. 9. ed. São Paulo: Malheiros, 2005. p. 77.

354 DANTAS, Francisco Clementino San Tiago. Programa de direito civil, p. 251.
} 
Assim, há o dano permitido, mas que demanda reparação prevista no $\S 3^{\circ}$ do artigo 1.313 do Código Civil como solução legislativa ao conflito, confirmando esta hipótese como de responsabilidade civil por conflito de direitos.

\subsubsection{Servidão de aqueduto}

O artigo 1.293 do Código Civil oferece a disciplina da canalização de águas indispensáveis às básicas necessidades das pessoas, permitindo a todos conduzir por prédios alheios as águas a que tenham direito, desde que, previamente, indenizem os proprietários dos prédios prejudicados.

Assim dispõe o caput do artigo em comento:

“Art. 1.293. É permitido a quem quer que seja, mediante prévia indenização aos proprietários prejudicados, construir canais, através de prédios alheios, para receber as águas a que tenha direito, indispensáveis às primeiras necessidades da vida, e, desde que não cause prejuízo considerável à agricultura e à indústria, bem como para o escoamento de águas supérfluas ou acumuladas, ou a drenagem de terrenos.

Este artigo adota a orientação do Código de Águas ${ }^{355}$ (Decreto n. 24.643/34), que no artigo 117 dispõe:

\footnotetext{
“A todos é permitido canalizar pelo prédio de outrem as águas a que tenham direito, mediante prévia indenização ao dono deste prédio: a) para as primeiras necessidades da vida; b) para os serviços da agricultura ou da indústria; c) para o escoamento das águas superabundantes; d) para o enxugo ou bonificação dos terrenos".
}

Demonstra-se assim a licitude daquele que age para canalizar águas por prédio alheio, desde que atendidas tais diretrizes legais, justificando o exercício regular de seu direito $^{356}$. As intervenções em terrenos alheios deverão ser as mínimas possíveis.

${ }^{355}$ MONTEIRO, Washington de Barros. Curso de direito civil. 37. ed. São Paulo: Saraiva, 2003. v. III, p. 148.

356 Diretrizes estabelecidas nos $\S \S 2^{\circ}$ e $3^{\circ}$ do artigo 1.293 ao disporem: " $\S 2^{\circ}$ O proprietário prejudicado poderá exigir que seja subterrânea a canalização que atravessa áreas edificadas, pátios, hortas, jardins ou quintais.§ $3^{\circ}$ $\mathrm{O}$ aqueduto será construído de maneira que cause o menor prejuízo aos proprietários dos imóveis vizinhos, e a expensas do seu dono, a quem incumbem também as despesas de conservação". 
Hely Lopes Meirelles corrobora ao afirmar: “A faculdade legal de canalizar águas através de terrenos alheio é ao mesmo tempo um direito do proprietário e uma restrição de vizinhança ${ }^{357}$."

Contudo o legislador, previamente, verifica que tal conduta colide frontalmente com o direito à propriedade dos terrenos de terceiros, que em nada concorrem para tal dano e apenas devem, por disposição legal, suportá-lo.

Deste conflito a solução oferecida é sobreposição do direito mais importante, o de constituir aqueduto, porém sendo atribuído aos prejudicados justa reparação. É o que dispõe o parágrafo primeiro do artigo 1.283 do Código Civil:

"§ $1^{\circ}$ Ao proprietário prejudicado, em tal caso, também assiste direito a ressarcimento pelos danos que de futuro lhe advenham da infiltração ou irrupção das águas, bem como da deterioração das obras destinadas a canalizá-las" ${ }^{\text {"358 }}$.

Assim, configura-se a hipótese de responsabilidade civil por colisão de direitos. A obrigação indenizatória visa ao reequílibrio de uma situação jurídica afetada pela escolha do legislador em permitir a sobreposição de um direito, considerado mais importante por sua necessidade, porém que causa dano permitido pelo ordenamento jurídico.

\subsection{4 Águas artificiais colhidas pelo prédio inferior}

A presença de águas que correm naturalmente de um prédio a outro devem ser toleradas $^{359}$. No entanto, no caso de o proprietário do prédio superior captar, extrair, ou colher águas artificialmente, e estas águas tiverem de correr para o prédio inferior, deverá

357 MEIRELLES, Hely Lopes. Direito de construir, p. 70.

358 No mesmo sentido o artigo 121 do Código de Águas (Decreto n. 24.643/34) ao permitir, inclusive, caução para este fim, ao dispor: "Art. 121. Os donos dos prédios servientes têm, também, direito a indenização dos prejuízos que de futuro vierem a resultar da infiltração ou irrupção das águas, ou deterioração das obras feitas, para a condução destas. Para garantia deste direito eles poderão desde logo exigir que se lhes preste caução."

359 Art. 1.288 do Código Civil. "O dono ou o possuidor do prédio inferior é obrigado a receber as águas que correm naturalmente do superior, não podendo realizar obras que embaracem o seu fluxo; porém a condição natural e anterior do prédio inferior não pode ser agravada por obras feitas pelo dono ou possuidor do prédio superior." 
ele, alternativamente, desviar tais águas do prédio inferior, utilizando, por exemplo, tubulações, ou indenizar o proprietário do prédio inferior ${ }^{360}$.

Assim disciplina a hipótese o artigo 1.289 do Código Civil:

“Art. 1.289. Quando as águas, artificialmente levadas ao prédio superior, ou aí colhidas, correrem dele para o inferior, poderá o dono deste reclamar que se desviem, ou se lhe indenize o prejuízo que sofrer.

Parágrafo único. Da indenização será deduzido o valor do benefício obtido”.

Assim, é licito ao proprietário de prédio superior conduzir suas águas artificialmente até o prédio inferior, porém deverá promover medidas no sentido de que tal condução não cause dano, ou, na sua ocorrência, que este, o proprietário do prédio inferior, seja indenizado.

Ilustra este ponto Hely Lopes Meirelles,

“muito comum é o confinamento das águas que antes corriam espalhadas sobre o terreno, canalizando-as por um só bueiro para o terreno inferior. Tal proceder é, sem dúvida, um empioramento da condição anterior das águas, porque confinadas, adquirem maior impetuosidade e provocam maior erosão e outros danos no embate entre as construções ou culturas inferiores ${ }^{361}$ ".

Dessa forma, fica justificada a reparação de danos sofridos pelo prejudicado.

Interessante notar que há dano permitido apenas em razão da alternatividade concedida ao proprietário do prédio inferior em exigir o desvio ou a indenização.

Tal alternatividade não ocorre no artigo 92 do Código de Águas (Decreto n. 24.643/34) que, tratando do mesmo tema, afirma:

\footnotetext{
"Art. 92. Mediante indenização, os donos dos prédios inferiores, de acordo com as normas da servidão legal de escoamento, são obrigados a receber as águas das nascentes artificiais.

Parágrafo único. Nessa indenização, porém, será considerado o valor de qualquer benefício que os mesmos prédios possam auferir de tais águas".
}

Neste caso, o dano permitido é claro, restando ao prejudicado, apenas a reparação.

Contudo, andou bem o Código Civil, visando ao menos a possibilidade de que o proprietário do prédio prejudicado possa, alternativamente, prevenir seu dano, ou ser

\footnotetext{
${ }^{360}$ PEREIRA, Caio Mário da Silva. Instituições de direito civil, p. 219.

361 MEIRELLES, Hely Lopes. Direito de construir, p. 72.
} 
devidamente indenizado. Caso a escolha seja pela indenização, estará configurada mais uma das hipóteses em estudo.

\title{
4.2.5 Elevação artificial das águas
}

Quanto à construção de barragens que elevam artificialmente o nível de águas invadindo prédio alheio, prevista no artigo 1.292 do Código Civil, verificamos também como uma das hipóteses em estudo.

O citado artigo dispõe:

\begin{abstract}
“Art. 1.292. O proprietário tem direito de construir barragens, açudes, ou outras obras para represamento de água em seu prédio; se as águas represadas invadirem prédio alheio, será o seu proprietário indenizado pelo dano sofrido, deduzido o valor do benefício obtido".
\end{abstract}

Verifica-se assim que o proprietário tem o direito de construir a barragem ${ }^{362}$. O ato de quem assim se conduz pela necessidade da utilização da barragem, é lícito.

Há, porém, a possibilidade de que o exercício de tal direito entre em colisão com direito de propriedade alheio. $\mathrm{Na}$ impossibilidade de conciliação prática destes direitos, o legislador oferece, como solução prévia, a sobreposição do direito a estabelecer barragem. O dano causado ao terreno de terceiro é permitido pelo ordenamento.

Contudo, por regra de justiça, estabelece o legislador a necessidade de reparação de danos causados ao prejudicado pelo exercício do direito, hipótese em que surge a responsabilização decorrente de conflito de direitos, como justa solução ao conflito.

${ }^{362}$ MONTEIRO, Washington de Barros. Curso de direito civil, v. III, p. 147. 


\title{
4.3 OBRIGAÇÃO DE COMPENSAR DANOS RESULTANTES DE RESTRIÇÕES AO DOMÍNIO EM VIRTUDE DO INTERESSE SOCIAL
}

O Estado no exercício de suas funções e cumprimento de seus objetivos poderá originar prejuízos a terceiros, especialmente nos casos em que prevalecerá o bem comum sobre o direito do indivíduo.

Nessas situações, há hipóteses de responsabilidade civil por conflito de direitos também no campo tradicionalmente dedicado ao Direito Público.

Inicialmente, é importante ressaltar a diferença de fundamentos existentes na responsabilidade civil por conflito de direitos no âmbito do direito público e do direito privado.

Verifica-se que, no direito privado o fundamento da obrigação reparatória está na igualdade entre os sujeitos da relação, sendo considerado injusto o prevalecer do direito de um sem que seja devida reparação ao outro. Por seu turno, enquanto hipótese relacionada ao direito público, o fundamento da responsabilidade reside não na igualdade entre os sujeitos, posto que o interesse público pretere o privado, mas na insuportabilidade por um sujeito dos ônus pelos benefícios que toda a coletividade usufruirá.

Gerard Cornu oferece-nos auxílio neste ponto ao afirmar que

\begin{abstract}
"O objetivo da responsabilidade não é exatamente o mesmo no direito público e no direito privado. Em um ou outro os atos visam a reparação de um dano. Todavia se deve ressaltar que a responsabilidade se situa aqui em planos diferentes: a reparação do dano em direito privado é restabelecer o equilíbrio entre dois patrimônios; em direito público, é restabelecer o equilíbrio entre os patrimônios de todos os contribuintes. A responsabilidade é apenas a repartição dos custos públicos",363.
\end{abstract}

363 CORNU, Gerard. Etude comparee de la responsabilite delictuelle en droit prive et en droit public. Reims: Matot-Braine, 1951. No original: "Le but de la responsabilité n'est pas exactement le même em droit public et em droit prive. Dans l'un et l'autre, il s'agit avant tout de la réparation d'un dommage. Encore faut-il remarquer qu'elle se situe ici et là dans deux plans différents: réparer le dommage en droit privé c'est rétablir l'équilibre entre deux patrimoines ; en droit public, c'est rétablir l'équilibre entre le patrimoines de tous les contribuables. La responsabilité n'est qu'un moyen de répartition des charges publiques". No mesmo sentido, é a posição do jurista lusitano Luiz da Cunha Gonçalves (Tratado de direito civil, § 1.858, p. 390), que, versando sobre as ocupações feitas pela administração pública por motivos urgentes e de força maior, afirma "Com efeito, os dois estados de necessidade assemelham-se na contingência ou dilema em que o autor de certo acto se vê, por ser forçoso escolher entre dois males - um mal maior próprio, que só se pode evitar causando a outrem um mal menor, se bem que indenizando-o. Mas, ao passo que no estado de necessidade de direito privado se trata de conflitos entre direitos e interesses de indivíduos, no estado de necessidade de direito público é sacrificado o 
Thompson Flores Lenz, sobre o mesmo tema, também funda esta categoria na repartição social dos custos da coisa pública afirmando:

\begin{abstract}
"em situações de intervenção do Poder Público, por justiça social, entende a doutrina que os eventuais danos produzidos em benefício de toda a coletividade devem ser socializados - repartidos - nessa mesma comunidade, a fim de não gerar injustiças, em respeito ao princípio da isonomia e a uma idéia de eqüidade, ${ }^{364}$.
\end{abstract}

Ou seja, é lícito ao Estado, para benefício da coletividade, ofender direito de particular, porém, a mesma coletividade deve indenizar o prejudicado, socializando, assim, seu sacrifício.

Diversas são as teorias referentes à responsabilização do Estado, especialmente no que se refere à responsabilidade objetiva relacionada aos riscos ${ }^{365}$.

Cumpre, neste trabalho, porém, limitar as hipóteses que o eminente jurista português José Joaquim Gomes Canotilho denominou "responsabilidade do Estado por actos lícitos" ${ }^{\text {366 }}$. Interessante notar que este autor não se vale do vocábulo "responsabilidade civil" para denominar as hipóteses em estudo. Elcio Trujillo nos esclarece que o uso do termo responsabilidade civil do Estado, embora consagrado na literatura jurídica, tem sido combatido por autores ligados ao Direito Público, uma vez que o termo "civil" poderia induzir a uma idéia de relação jurídica regulada pelo Direito Privado no tocante à responsabilidade do Estado ${ }^{367}$. No entanto, manteremos a denominação tradicional para aproximação dos sistemas.

Assim, na responsabilidade civil do Estado por atos lícitos há ato que "se dirige à produção de um dano na esfera jurídica de outrem: o agente lesante tem a certeza, consciência e vontade de causar um prejuízo. Deste modo, o dano querido é, na responsabilidade por actos lícitos, um elemento inseparável da acção"368.

direito de um partículas ao interesse da coletividade, havendo uma desigualdade qualitativa dos dois sujeitos, como nas expropriações em geral. Pode dizer-se que o conceito de estado de necessidade acresce aos factôres normais da expropriação, que são a utilidade pública e a necessidade pública".

${ }^{364}$ LENZ, Luis Alberto Thompson Flores. A responsabilidade civil do Estado pela prática de ato lícito, Revista Justitia, v. 172, out./dez. 1995, p. 78 e ss.

365 CAVALIERI FILHO, Sergio. Programa de responsabilidade civil, p. 248.

${ }^{366}$ CANOTILHO, José Joaquim Gomes. O problema da responsabilidade do estado por actos lícitos. Coimbra: Almedina, 1974. p. 12.

367 TRUJILLO, Elcio. Responsabilidade do estado por ato lícito, p. 36 e ss.

368 CANOTILHO, José Joaquim Gomes. O problema da responsabilidade do estado por actos lícitos, p. 79. 
Elcio Trujillo aponta que a responsabilidade por ato lícito decorrente de atividade do Estado "será indenizável quando o ato, embora lícito, motivado pelo interesse público, causar um prejuízo especial e anormal [ao particular] ${ }^{369,}$.

O autor apresenta como exemplos de responsabilidade por ato lícito do Estado $^{370}$ os atos administrativos executivos de obras públicas, como os danos causados a particular em decorrência de elevação do nível da rua, que obstrui a entrada para garagem de particular ${ }^{371}$, ou decorrentes de implantação de novo zoneamento urbano ${ }^{372}$.

Todavia, estes são exemplos que sistematicamente tratamos como hipóteses de responsabilidade por conflito de direitos na modalidade ex iudicio, ou seja, naquelas em que o julgador, posteriormente ao conflito, conclui pelo cabimento da reparação dos danos causados pela atividade lícita que causa dano.

Na modalidade em estudo, ou seja, de responsabilidade decorrente da opção do legislador ao solucionar um conflito de direitos, verificamos que a mais relevante, relacionada à responsabilidade do Estado, refere-se à indenização cabal devida ao proprietário de prédio a ser desapropriado ou em que se constituirá servidão administrativa.

369 TRUJILLO, Elcio. Responsabilidade do estado por ato lícito, p. 101.

370 TRUJILLO, Elcio. Responsabilidade do estado por ato lícito, p. 107 e ss.

371 Exemplos oferecidos são seguintes, constantes dos acórdãos do Tribunal de Justiça do Estado de São Paulo: "Responsabilidade civil do Município - Construção de viaduto - Graves prejuízos a prédio residencial - Indenização devida - Ação procedente. O prejuízo causado a prédio, por construção municipal, não exige prova de culpa da Municipalidade, pois que a questão se desloca para o campo da causalidade" (Revista dos Tribunais, v. 453, p. 75) e "Responsabilidade civil do Município - Construção de viaduto - Danos a prédios vizinhos - Indenização devida - Correção monetária - Recurso provido em parte - Voto vencido. A Municipalidade responde pelos prejuízos causados a prédio particular por motivo de obra pública que o deixou em nível inferior. A correção monetária é devida, embora não pedida na inicial". (Revista dos Tribunais, v. 537, p. 108).

372 Tribunal de Justiça do Estado de São Paulo "Responsabilidade civil do Município - Projeto de construção Decretos estabelecendo restrições - Impedimento quando já havia direito adquirido - Indenização devida Recursos providos em parte - Voto vencido. Pode a Administração Pública revogar seus próprios atos, por motivos de conveniência ou oportunidade, respeitados os direitos adquiridos". (Revista dos Tribunais, v. 543, p. 102). 


\title{
4.3.1 Desapropriação
}

A desapropriação constitui um "ato unilateral de direito público, com reflexos no direito privado, por via do qual a propriedade individual é transferida, mediante prévia e justa indenização em dinheiro, a quem dela se utiliza, no interesse da coletividade" ${ }^{\text {,73. }}$.

Nesse sentido, o proprietário que foi indenizado previamente, de modo justo, pode ser privado do direito de propriedade que tem sobre uma coisa em favor da administração pública, quando isto lhe seja exigido por motivos de interesse público. Em âmbito constitucional, sua previsão é feita primordialmente pelo artigo $5^{\circ}$, inciso XXIV, que versa:

\begin{abstract}
"Art. $5^{\circ}$ Todos são iguais perante a lei, sem distinção de qualquer natureza, garantindo-se aos brasileiros e aos estrangeiros residentes no País a inviolabilidade do direito à vida, à liberdade, à igualdade, à segurança e à propriedade, nos termos seguintes: (...) XXIV - a lei estabelecerá o procedimento para desapropriação por necessidade ou utilidade pública, ou por interesse social, mediante justa e prévia indenização em dinheiro, ressalvados os casos previstos nesta Constituição".
\end{abstract}

Assim, na hipótese, verificamos a presença de ato lícito ao Estado de determinar a desapropriação de bem, no interesse da coletividade. A indenização decorrente de tal ato, obviamente, em nada decorre de conduta ilícita do Estado, fato que afasta por completo qualquer possibilidade de sistematização desta indenização como decorrente de conduta culposa.

No entanto, verifica-se, no caso, o conflito lícito de direitos entre o particular e o Estado, este último, representando o interesse público. Pela licitude do ato, é a lição de Orlando Gomes ao afimar: "Assegura-se o direito à indenização em conseqüência de ato lícito não só quando o proprietário suporta tais limitações ${ }^{374}$, mas, também, quando perde a propriedade por desapropriação ${ }^{375,}$.

Constata-se também a prevalência do direito mais importante, qual seja, neste caso, o interesse público. Pontes de Miranda afirma que, na solução dos casos de

\footnotetext{
373 MONTEIRO, Washington de Barros. Curso de direito civil, v. III, p. 171.

$374 \mathrm{O}$ autor refere-se às limitações impostas ao exercício do direito de propriedade pelas relações decorrentes dos Direitos de Vizinhança.

375 GOMES, Orlando. Direitos reais, p. 297.
} 
desapropriação, em que o interesse público se contrapõe ao particular, importa o princípio do interesse mais relevante ${ }^{376}$.

Simultaneamente, há a previsão de o Estado assumir a obrigação de compensar os danos sofridos pelo particular ${ }^{377}$, configurando assim o tipo da responsabilidade civil por conflito de direitos.

Não se segue, dessa forma, a sistematização dada por João Matos Antunes Varela, na hipótese da indenização decorrente de desapropriação, tratando-a como mero pagamento, assemelhando este tipo de responsabilidade a uma "venda forçada".

São as palavras do citado autor:

\begin{abstract}
"Na desapropriação por utilidade pública ou por interesse social, há também, para a entidade desapropriante, a obrigação de pagar a justa indenização, medida pelo prejuízo que o desapropriado sofre com a perda do direito. Mas não há responsabilidade civil. $\mathrm{O}$ fato gerador do prejuízo $-\mathrm{o}$ ato jurídico da desapropriação - contém já como seu elemento integrante a obrigação de prestar o equivalente e nisso se distingue do denominado confisco de bens. Sendo em certo equiparável a uma venda forçada ou a má arrematação judicial, da desapropriação não nasce um dano, porque a perda do desapropriado é compensável, dentro da estrutura jurídica própria do ato desapropriativo, mediante o preço da coisa",378.
\end{abstract}

Acredita-se, em primeiro lugar, na inviabilidade de se sustentar uma compra e venda sem consentimento do vendedor. Em segundo, que, se pagamento fosse, seria discutido pelas partes e não imposto por uma delas, relegando à outra apenas a via judicial de revisão.

Por fim, a própria Constituição Federal de 1988, em seu artigo $5^{\circ}$, inciso XXIV, anteriormente citado, afirma ser uma indenização, a prestação devida pela administração pública nos casos de desapropriação ${ }^{379}$.

Esta indenização constitui uma compensação de um dano sofrido pelo exercício de um interesse da coletividade ao qual, não sendo justo ao danado suportar sozinho o benefício de todos, a própria coletividade, por meio do Estado, prevê uma indenização a

376 PONTES DE MIRANDA, Francisco Cavalcanti. Tratado de direito privado, t. II, p. 437.

377 DE CUPIS. Adriano. Il danno, p. 25.

378 VARELA, João Matos Antunes. A responsabilidade no direito, p. 8. O eminente jurista português entende não ocorrer dano ao que sofre a ação da administração pública, por haver, no próprio decreto de desapropriação, a previsão de indenização. $\mathrm{O}$ dano existe, mas o fato de ter sido previsto a priori pelo legislador não altera sua natureza.

379 No mesmo sentido de Antunes Varela, porém, no tocante às relações de direito de vizinhança, e CHAPUS, René. Responsabilité publique et resposabilité privée, § 336, p. 339. 
ele compensatória, sendo esta pertencente à categoria da responsabilidade civil por conflito de direitos.

\subsubsection{Servidão Administrativa}

Também como restrições do Estado à propriedade privada, verifica-se a possibilidade da instituição de servidão administrativa como hipótese de responsabilidade por conflito de direitos.

Em sentido amplo, a servidão administrativa constitui-se "direito real de gozo, de natureza pública, instituído sobre imóvel de propriedade alheia, com base em lei, por entidade pública ou por seus delegados, em favor de um serviço público ou um bem afetado a fím de utilidade pública ${ }^{380}$. Ou ainda a servidão administrativa é o "ônus real de uso, imposto especificamente pela Administração a determinados imóveis particulares, para possibilitar a realização de obras e serviços público"381.

É constituída não em favor do prédio confinante, mas, sim, da prestação de um serviço público.

A sua instituição visa ao atendimento de interesse público sendo, em regra, gratuita. Contudo é cabível indenização dos prejudicados no caso em que haja sacrifício especial e anormal ao prejudicado, como normalmente ocorre no caso de servidão administrativa incidente sobre imóveis ${ }^{382}$.

É o caso, por exemplo, de servidão administrativa decorrente de declaração de utilidade pública, em procedimento semelhante ao da desapropriação previsto no artigo 40 do Decreto-Lei n. 3.365/41, que afirma:

380 DI PIETRO, Maria Sylvia Zanella. Direito administrativo. 19. ed. São Paulo: Atlas, 2006. p. 125.

381 NASCIMENTO, Tupinanbá Miguel Castro do. Direito real de servidão. Rio de Janeiro: AIDE, 1985. p. 258.

382 Tribunal de Justiça de Minas Gerais. "Constituição de servidão administrativa - Indenização - Comprovado que a constituição de servidão administrativa sobre determinado imóvel, embora não implique transferência do respectivo domínio, acarreta severas restrições ao seu uso e o desvaloriza comercialmente, a indenização deve ter como parâmetro, portanto, não o valor da faixa de servidão, mas a expressão econômica do desfalque patrimonial resultante do apossamento administrativo". (APCV 000.332.350-8/00- 1ª C. Cív., rel. Des. Francisco Lopes de Albuquerque, j. 27.05.2003). 
"Art. 40. O expropriante poderá constituir servidões, mediante indenização na forma desta lei."

Nesse sentido, também o Código Civil vigente, atento às necessidades, ao avanço da tecnologia e da prestação de serviços públicos, contempla especificamente a passagem de cabos e tubulações e outros condutos subterrâneos de serviços de utilidade pública ${ }^{383}$, conforme previsão do caput do artigo 1.286:

\footnotetext{
“Art. 1.286. Mediante recebimento de indenização que atenda, também, à desvalorização da área remanescente, o proprietário é obrigado a tolerar a passagem, através de seu imóvel, de cabos, tubulações e outros condutos subterrâneos de serviços de utilidade pública, em proveito de proprietários vizinhos, quando de outro modo for impossível ou excessivamente onerosa”.
}

Considera-se a hipótese do artigo 1.286 como servidão administrativa, como expressamente o faz Maria Helena Diniz, uma vez que o que sobressai é a utilidade pública da servidão ${ }^{384}$. Contudo tal consideração leva a uma conclusão importante: ao se tratar a hipótese do artigo 1.826 como caso de servidão administrativa, a indenização será devida exclusivamente pela Administração Pública.

Nos limites do presente estudo, afirmamos que todas as considerações referentes à desapropriação como hipótese específica de responsabilidade por conflito do direito são, neste trabalho, aplicáveis ao caso da servidão administrativa em que há a obrigação de indenizar o prejudicado, configurando esta hipótese de responsabilidade civil por conflito de direitos.

\subsection{OBRIGAÇÃO DE COMPENSAR DANOS RESULTANTES DO EXERCÍCIO DA TUTELA JURÍDICA}

Questão interessante se apresentou nesta pesquisa, mesmo que o tema seja mais afeito ao direito processual, diz respeito ao fundamento da obrigação de compensar danos causados em conseqüência de medidas judiciais liminares requeridas e executadas por uma das partes antes que haja sentença transitada em julgado sobre aquele assunto.

\footnotetext{
383 MEIRELLES, Hely Lopes. Direito de construir, p. 78.

384 DINIZ, Maria Helena. Curso de direito civil brasileiro, 21. ed., v. IV, p. 284.
} 
Tal medida judicial liminar pode ser concedida pelos mais variados motivos e formas: medida cautelar ${ }^{385}$, antecipação da tutela ${ }^{386}$, execução provisória ${ }^{387}$. Todas elas, no entanto, guardam como similitude o fato de que sua execução ocorre em exercício de direito concedido pelo Poder Judiciário, de uma atitude que ainda está em discussão, porém, por sua necessidade ou importância, é permitida antes de esgotada a cognição total sobre a questão.

Apesar de se admitir as demais hipóteses neste trabalho, limitar-se-á ao exame das tutelas concedidas apenas em ações cautelares por trazerem os mesmos princípios de todas as outras formas de responsabilização ${ }^{388}$.

A medida liminar nada mais é do que o produto da classificação das tutelas quanto ao momento em que são dadas pelo juiz, isto é, fora da sentença, ou in limine processus. Entretanto, neste momento, interessa um tipo específico destas tutelas, a cautelar.

As ações cautelares, como espécie das medidas liminares, são ações que visam a providências urgentes e provisórias, tendentes a assegurar os efeitos de uma providência principal, em perigo por eventual demora ${ }^{389}$. Visam, portanto, à proteção do processo ${ }^{390}$, isto é, o seu resultado prático útil, pela proteção do objeto do processo que, sem a cautela, fatalmente pereceria. Fica evidente o caráter de instrumental do processo.

Para a sua concessão, é necessária a prova de dois requisitos, quais sejam: fumus boni iuris, isto é, que haja a provável existência de um direito a ser resguardado no processo principal, e o periculum in mora, ou seja, o temor de que, enquanto aguarda a tutela definitiva, venham a faltar as circunstâncias, de fato, favoráveis à própria tutela ${ }^{391}$. No balanço adequado dos fatos, fica a critério do julgador a decisão sobre a existência destes elementos e a concessão da medida liminar.

385 Artigo 796 e ss do Código de Processo Civil.

386 Artigo 273 do Código de Processo Civil.

387 Artigo 588 do Código de Processo Civil.

388 Apesar do fato de que concordamos que a característica da cautelaridade da ação cautelar não se confunde com a provisoriedade da execução provisória, pois são institutos diferentes quanto a sua finalidade. Cf. PONTES DE MIRANDA, Franscisco Cavalcanti. Comentários ao Código de Processo Civil. Rio de Janeiro: Forense, 1976, t. XII, p. 99 e BATISTA DA SILVA, Ovídio A. Curso de processo civil. 2 ed. São Paulo: RT, 1998. p. 50.

389 SANTOS, Moacir Amaral. Primeiras linhas de direito processual civil. 7. ed. São Paulo: Saraiva, 1980.

390 Sobre a dualidade entre segurança e efetividade do processo cf. BATISTA DA SILVA, Ovídio A. Curso de processo civil, p. 11.

391 THEODORO JR., Humberto. Processo cautelar, p. 73 e ss. 
No entanto, a questão a ser enfrentada refere-se ao caso de concessão da medida liminar, visando à proteção do processo, mas que, posteriormente, após esgotada a cognição e julgada a questão, verifica-se que não assistia direito ao vencedor da medida liminar.

Foi para estes casos, que o Código de Processo Civil brasileiro, a exemplo da legislação estrangeira ${ }^{392}$, mais especificamente a alemã, previu em seu artigo 811 a responsabilização por danos causados em medidas cautelares. Aponta este artigo:

\begin{abstract}
Art. 811. Sem prejuízo do disposto no Art. 16, o requerente do procedimento cautelar responde ao requerido pelo prejuízo que lhe causar a execução da medida: I - se a sentença no processo principal lhe for desfavorável; II - se, obtida liminarmente a medida no caso do Art. 804 deste Código, não promover a citação do requerido dentro em 5 (cinco) dias; III - se ocorrer a cessação da eficácia da medida, em qualquer dos casos previstos no Art. 808, deste Código; IV - se o juiz acolher, no procedimento cautelar, a alegação de decadência ou de prescrição do direito do autor (Art. 810).
\end{abstract}

A este estudo interessa a hipótese específica do inciso $\mathrm{I}^{393}$. Cumpre, assim, ao requerente de medida cautelar indenizar ao requerido, caso a sentença lhe seja desfavorável.

Como ilustração, cita-se o exemplo de concessão de medida liminar que visou impedir a venda de determinado livro sob a alegação de ofensa ao direito de intimidade da pessoa nele retratada. Para assegurar o resultado prático e a efetividade da jurisdição, o julgador concede a cautela, mas, ao final, chega-se à conclusão de que são perfeitamente legítimas ao autor e à editora as considerações presentes na publicação. Neste caso, por força da circunstância tipificada em lei, é devido ressarcimento àquele que suportou, com prejuízo para si (por exemplo, vendas perdidas e cancelamento de contratos de publicidade), a medida cautelar.

Pode ser verificada a presença de índices caracterizadores da responsabilidade civil por conflito de direitos no exemplo citado.

\footnotetext{
392 Para uma análise das legislações estrangeiras ver BATISTA DA SILVA, Ovídio A. Comentários ao Código de Processo Civil. Porto Alegre: LEJUR, 1985. p. 246 e ss.

${ }^{393}$ Para um exame mais aprofundado da questão cf. THEODORO JR., Humberto. Processo cautelar, p. 177 e ss.; MOREIRA, José Carlos Barbosa. Responsabilidade do requerente de medida cautelar, p. 109 e ss. Especificamente nas hipóteses dos incisos II e III do artigo 811, relacionados ao artigo 808 I do mesmo diploma legal, a responsabilidade surge por um ato de negligência do autor da cautelar e reputa-se caso de responsabilização decorrente de culpa, e, portanto, subjetiva, no sentido do autor não haver diligenciado com o devido cuidado negócios de seu interesse e, com este ato, ferir direito alheio causando dano. Deve aquele que exerceu seu direito de obter medida cautelar, indiscutivelmente indenizar o prejudicado, decorrente de culpa sua.
} 
Primeiro, a obrigação de indenizar decorre de ato em conformidade com o ordenamento jurídico, isto é, em atitude lícita ${ }^{394}$. O direito de estar em juízo é lícito e garantido pelo ordenamento jurídico ${ }^{395}$. Afasta-se, assim, que este fundamento decorra de conduta culposa.

Se fosse hipótese de responsabilidade subjetiva, o autor teria de agir com dolo ou culpa ao pedir a medida cautelar para que ocorresse a reparação. Não é o caso. É mais do que pacífico jurisprudencialmente que não é necessária a má-fé (ou dolo, isto é, intenção de prejudicar), para que haja indenização ${ }^{396}$. Além disso, se esta fosse a hipótese, ela seria desnecessária, tendo em vista já existir o princípio da responsabilidade por má-fé processual, previsto no artigo 16 do Código de Processo Civil.

Nesse sentido, o julgamento no Superior Tribunal de Justiça do Recurso Especial n. 11.090/SP, cujo relator foi o Ministro Waldemar Zveiter, em 22/10/1991: "Processual Civil - Medida Cautelar de Sequestro - Ação de dissolução e liquidação de sociedade Litigância de má-fé não demonstrada - Indenização - Responsabilidade Objetiva Interpretação do art. 811 do CPC. I - Questão relativa a existência ou não da má-fé imputada ao autor, cujo deslinde implicaria no reexame de matéria de fato, defeso no âmbito do Especial (Súmula n. 7 do STJ). II - Consoante a melhor doutrina, o código estabelece que responda pelos prejuízos, que causar, a parte que de má-fé, ou não, promove medida cautelar. Basta o prejuízo, se ocorrer qualquer das hipóteses do artigo 811”.

Assim, não há que se cogitar de culpa, uma vez que é perfeitamente indenizável o dano, mesmo causado por aquele que agir com o cuidado e diligência legítimos, mas tenha uma questão a ser resolvida pelo Poder Judiciário, e necessite, para que esta decisão não se torne inútil, de uma medida cautelar.

Causando dano, e sobrevindo decisão de que a parte contrária é a verdadeira detentora do direito, o requerente da medida cautelar, deve indenizar. Não é no sistema da responsabilidade extracontratual subjetiva que está o fundamento de tal indenização.

\footnotetext{
394 FORNACIARI JUNIOR, Clito. Dos prejuízos decorrentes da execução de medida cautelar, p. 78 e ss.

395 AMARANTE, Aparecida. Excludentes de ilicitude civil, p. 103.

${ }^{396}$ Cf. ainda Recurso Especial n. 15.853/RS, Recurso Especial n. 30.368/RS, Recurso Especial n. 34.899/SP, Recurso Especial n. 55.870/SP, Recurso Especial n. 89.788/RJ. Recurso Especial n. 127.498/RJ e Recurso Especial n. 193.366/SP.
} 
Identifica-se também o conflito de direitos existente no plano processual entre o direito à efetividade da jurisdição versus a segurança jurídica ${ }^{397}$, formando uma tensão, sem o rompimento do ordenamento jurídico, mas em posições contrárias e excludentes. Esta é a tensão que há de ser solucionada, já que, na prática, torna-se impossível a conciliação total dos direitos.

Há também a solução legislativa para este conflito, prevista pelo legislador, $a$ priori, pelo artigo 811, inciso I do Código de Processo Civil, segundo o qual, no conflito é possível ao julgador conceder a medida liminar e garantir o resultado prático da jurisdição. Permite-se o dano, desde que, fique garantida e estabelecida a sua reparação.

Há aqui também a sobreposição do direito considerado mais importante, mais um índice caracterizador da responsabilidade civil por conflito de direitos.

Pontes de Miranda versando sobre os princípios que levam à aparição de atosfatos jurídicos, a acena com existência do princípio da responsabilidade pelo exercício da tutela jurídica ${ }^{398}$ próprio à situação comentada. Este princípio seria, em suas palavras, “o da restauração ou indenização do dano que se haja causado por se ter exercido a autotutela, ou justiça de mão própria, Selbsthülfe, ou a pretensão a tutela jurídica por segurança ou adiantamento (arresto, seqüestro e outras medidas cautelares)"399.

Importante verificar que não há risco ao que suporta a medida cautelar, mas há dano legitimamente autorizado ao qual se deve, por medida de política legislativa, indenizar.

Como anteriormente citado, Humberto Theodoro Júnior argumenta pela similitude da situação ao estado de necessidade: "tudo se passa à semelhança do ato danoso praticado em estado de necessidade. O agente tinha o direito reconhecido de praticá-lo, mas se a vítima não tinha o dever de suportar o prejuízo, cabe ao agente proceder ao competente ressarcimento, embora tenha agido na licitude ${ }^{„ 400}$. Ou seja, do exercício legítimo, sem abusos, de um direito (por exemplo, a defesa do processo por meio de uma

397 Constituição Federal artigo 5º inciso LIV: "Ninguém será privado da liberdade ou de seus bens sem o devido processo legal".

398 PONTES DE MIRANDA, Francisco Cavalcanti. Tratado de direito privado, t. II, p. 437.

399 PONTES DE MIRANDA, Francisco Cavalcanti. Tratado de direito privado, t. II, p. 437. No entanto, cumpre esclarecer que, baseado no Código de Processo Civil de 1939, Pontes de Miranda nega sua existência no ordenamento jurídico brasileiro.

400 THEODORO JR., Humberto. Processo cautelar, p. 186. 
medida cautelar) resulta um dano, ao qual a parte contrária não é obrigada a suportar, e, por isso, é fonte de reparação.

Assim, presentes os índices caracterizadores da responsabilidade civil por conflito de direitos, chega-se à conclusão de que a hipótese enseja enquadramento com relação à responsabilidade objetiva na modalidade em comento. 


\section{CONCLUSÃO}

Pode-se afirmar que este trabalho versou, em primeiro plano, sobre a existência da responsabilidade civil ex lege por colisão de direitos, seu posicionamento sistemático, seus elementos intrínsecos e as excludentes de sua aplicação.

Demonstrou-se que o conflito, além de uma constante social, também é passível de ocorrer no âmbito do ordenamento jurídico, seja por motivos econômicos, seja por motivos de ordem lógica. No entanto, este conflito em abstrato deve, por quaisquer mecanismos, desaparecer quando da ocorrência da situação em concreto.

Caso o mecanismo utilizado para solucionar o conflito interno do ordenamento jurídico seja dado pelo legislador e tenha como resultado a sobreposição de um direito a outro, desde que aquele que teve seu direito tolhido fosse devidamente indenizado, revela-se aí a responsabilidade civil ex lege por colisão entre direitos. Trata-se de responsabilidade em sua forma objetiva, isto é, em que não há, para sua determinação, a apuração de culpa daquele que a cometeu. Pelo contrário, a conduta que a enseja é de exercício regular de direito, o que representaria uma excludente de responsabilidade, caso tratássemos de responsabilidade subjetiva.

Dessa forma, delinearam-se três fundamentos para a responsabilidade civil: o primeiro, a conduta ilícita, na qual o agente ofende direito ou bem alheio, contrariando o ordenamento jurídico; o segundo, a atividade que possui um risco intrínseco de dano e, apesar de admitida pelo ordenamento jurídico, todo o dano que dela provier deverá ser indenizado; e, por fim, a terceira hipótese é aquela na qual há um conflito entre direitos, em que, para sua solução, um deles, o menos valioso do ponto de vista ético e humano, cessará, definitiva ou transitoriamente, mediante indenização, sobrepondo-se a ele um mais importante. 
A responsabilidade civil ex lege por colisão de direitos é, assim, um fundamento autônomo da obrigação de indenizar. Este fundamento foi aplicado em hipóteses que julgamos adequadas ao seu tipo, como categoria jurídica, mas também foram apresentadas hipóteses em que este enquadramento não era pertinente.

Cumpre retomar, no entanto, que a colisão de direitos, fundamento da responsabilidade, provém da incapacidade de o ordenamento jurídico ser um sistema fechado, completo e livre de antinomias. Por mais que se busque evitar suas contradições internas, elas lhe são intrínsecas. De certa forma, é o preço pago pela incorreção necessária que a metodologia do direito precisa para o acompanhamento das transformações sociais. Direito, em si, não é exato, mas humano.

O Direito é ciência social que necessita dar aberturas à sociedade. Como expressão de cultura, deverá ser sensível às modificações da realidade, visando a evolução e a modificação do sistema. Contudo, não se deve pensar num enfraquecimento do Direito na solução das crises sociais, mas, sim, numa transformação de seu conceito, visando atender a nova sociedade contemporânea.

Assim, buscou-se demonstrar a existência de um fundamento do instituto da responsabilidade civil que refletisse alguma dessas questões. Pelo estudo da categoria, por essa ser ampla em abstração e generalidade, permitiu melhor vislumbrar os demais fundamentos da responsabilidade civil. Operar com as hipóteses extremas permite compreender melhor o centro da categoria jurídica. Este foi o objetivo deste trabalho.

Neste início de século, a pesquisa em direito privado se presta a isto: da controvérsia dogmática, questionar os fundamentos reais do instituto e, por que não, o próprio instituto.

Todavia, por mais imperfeito e contraditório que seja o Direito, deve haver sempre a busca de sua sistematização para harmonizar seus elementos e avivar seus objetivos de valorização do ser humano, e, in casu, atribuir a este as conseqüências de suas ações.

Caso tenhamos ao menos fomentado qualquer novo pensamento, seja no âmbito da Responsabilidade Civil, seja no âmbito da Teoria Geral do Direito, todo o esforço já terá sido recompensado. 


\section{REFERÊNCIAS}

ALEXY, Robert. Colisão de direitos fundamentais e realização de direitos fundamentais no Estado de direito democrático. Revista de Direito Administrativo, n. 217, Rio de Janeiro, 1999.

ALEXY, Robert. Direitos fundamentais no estado constitucional democrático. Revista de Direito Administrativo, n. 217, Rio de Janeiro, p. 65, 1999.

ALEXY, Robert. Ponderação, jurisdição constitucional e representação popular. In: SARMENTO, Daniel; SOUZA NETO, Cláudio Pereira de. A constitucionalização do Direito. Rio de Janeiro: Lúmen Júris, 2007.

ALPA, Guido; BESSONE, Mario. Atipicità dell'illecito: parte prima. 2. ed. Milano: Giuffrè Editore, 1980.

ALPA, Guido; BESSONE, Mario. Elementi di diritto privato. 1. ed. Bari: Laterza, 2001.

ALPA, Guido; BESSONE, Mario. La responsabilità civile. 2. ed., Milano: Giuffrè Editore, 1980. v. 1-2.

AMARAL, Francisco. Direito civil: introdução. 5. ed. rev., atual. e aum. Rio de Janeiro: Renovar, 2003.

AMARANTE, Aparecida. Excludentes de ilicitude civil. Belo Horizonte: Del Rey, 1999.

ARMELIN, Donaldo. Responsabilidade objetiva no Código de Processo Civil. In: CRUZ E TUCCI, José Rogério (Coord.). Processo Civil: estudo em comemoração aos 20 anos de vigência do Código de Processo Civil. São Paulo: Saraiva, 1995.

AZEVEDO, Álvaro Villaça. Proposta de classificação da responsabilidade objetiva: pura e impura. Revista dos Tribunais, São Paulo: RT, v. 698, dez. 1993. 
AZEVEDO, Álvaro Villaça. Teoria geral das obrigações: responsabilidade civil. 10. ed. São Paulo: Atlas, 2004.

BARROSO, Luis Roberto. Interpretação e aplicação da Constituição. 6. ed. São Paulo: Saraiva, 2004.

BATISTA DA SILvA, Ovídio A. Comentários ao Código de Processo Civil. Porto Alegre: LEJUR, 1985.

BATISTA DA SILVA, Ovídio A. Curso de processo civil. 2 ed. São Paulo: RT, 1998.

BAPTISTA, Silvio Neves. Ensaio sobre a teoria do fato danoso. Revista de Direito Civil, Imobiliário, Agrário e Empresarial, São Paulo: RT, n. 67, jan./mar. 1994.

BAPTISTA, Silvio Neves. Teoria geral do dano: de acordo com o novo Código Civil brasileiro. São Paulo: Atlas, 2003.

BEVILÁQUA, Clóvis. Código Civil dos Estados Unidos do Brasil comentado. 10. ed. São Paulo: Francisco Alves, 1957. v. V.

BEVILÁQUA, Clóvis. Código Civil dos Estados Unidos do Brasil comentado. 10. ed. São Paulo: Francisco Alves, 1953. v. I.

BITTAR, Carlos Alberto. Responsabilidade civil nas atividades nucleares. São Paulo: RT, 1982.

BITTAR, Carlos Alberto. Responsabilidade civil: teoria e prática. 3. ed. Rio de Janeiro: Forense Universitária, 1999.

BOBBIO, Norberto. A era dos direitos. Rio de Janeiro: Campus, 1992.

BOBBIO, Norberto. Teoria do ordenamento jurídico. 8. ed. Brasília: Editora da UnB, 1996.

CANARIS, Claus-Wilheim. Pensamento sistemático e conceito de sistema na ciência do direito. Tradução de A. Menezes Cordeiro. 2. ed. Lisboa: Calouste Gulbekian, 1996.

CANOTILHO, José Joaquim Gomes. Direito Constitucional. 5. ed. Coimbra: Almedina, 1992. 
CANOTILHO, José Joaquim Gomes. O problema da responsabilidade do estado por actos lícitos. Coimbra: Almedina, 1974.

CASTILLA, Gustavo Ordoqui. Obligación de compensar daños causados por conductas lícitas. Revista dos Tribunais, São Paulo, n. 726, 1996.

CAVALIERI FILHO, Sergio. Programa de responsabilidade civil. 6. ed. São Paulo: Malheiros, 2006.

CHAPUS, René. Responsabilité publique et resposabilité privée. Paris: Librairie Générale de Droit et de Jurisprudence, 1954.

CHIRONI, G. P. La colpa nel diritto civile odierno. 2. ed. Torino: Fratelli Bocca, 1906. v. II.

COMPARATO, Fabio Konder. Direitos e deveres fundamentais em matéria de propriedade. Disponível em: <http://www.cjf.gov.br/revista/numero3/artigo11.htm> Acesso em: 02 jan. 2007.

CORNU, Gerard. Etude comparee de la responsabilite delictuelle en droit prive et en droit public. Reims: Matot-Braine, 1951.

COUTO E SILVA, Clóvis V. do. O conceito de dano no direito brasileiro e comparado. Revista dos Tribunais, São Paulo, n. 667, maio 1991.

CRUZ, Gisela Sampaio da. O problema do nexo causal na responsabilidade civil. Rio de Janeiro: Renovar, 2005.

DANTAS, Francisco Clementino San Tiago. O conflito de vizinhança e a sua composição. Rio de Janeiro, 1939.

DANTAS, Francisco Clementino San Tiago. Programa de direito civil. Rio de Janeiro: Editora Rio, 1979. v. 3.

DE CUPIS, Adriano. Il danno: teoria generale della responsabiltà civile. 2. ed. Milão: Giuffrè, 1966. v. 1.

DE LORENZO, Miguel Federico. El daño injusto en la responsabilidad civil. Buenos Aires: Abeledo-Perrot, 1996. 
DE PAGE, Henri. Traité elémentaire de droit civil Belge. Paris: Sirey, 1934. t. II.

DI PIETRO, Maria Sylvia Zanella. Direito Administrativo. 19. ed. São Paulo: Atlas, 2006.

DIAS, José de Aguiar. Da responsabilidade civil. 10. ed. Rio de Janeiro: Forense, 1997.

DÍAZ, Julio Alberto. Responsabilidade coletiva. Belo Horizonte: Del Rey, 1998.

DINIZ, Maria Helena. Curso de direito civil brasileiro. 20. ed. São Paulo: Saraiva, 2006. v. 7.

DINIZ, Maria Helena. Curso de direito civil brasileiro. 21. ed. São Paulo: Saraiva, 2006. v. 4.

ENNECERUS, Ludwig; LEHMANN, Heinrich. Lehrbuch des Bürgerlichen Rechts, Band 2: Recht der Schuldverhältnisse. Tübingen: Tübingen, 1958.

ENGISH, Karl. Introdução ao pensamento jurídico. 6. ed. Lisboa: F. Calouste Gulbenkian, 1983.

FARIAS, Edilsom Pereira de. Colisão de direitos. Porto Alegre: Safe, 1996.

FIGUEIRA, Eliseu. Renovação do sistema de direito privado. Lisboa: Editorial Caminho, 1989.

FORNACIARI JUNIOR, Clito. Dos prejuízos decorrentes da execução de medida cautelar. Revista Ajuris, Porto Alegre, n. 35, nov. 1985.

GAGLIANO, Pablo Stolze; PAMPLONA FILHO, Rodolfo. Novo curso de direito civil: contém análise comparativa dos códigos de 1916 e 2002. São Paulo: Saraiva, 2004. v. III.

GAGLIANO, Pablo Stolze; PAMPLONA FILHO, Rodolfo. Novo curso de direito civil. 7. ed. São Paulo: Saraiva, 2006. v. I.

GHERSI, Carlos A. Responsabilidad por actos lícitos. In: BUERES, Alberto José et al (Coord.). Responsabilidad por daños en el tercer milenio. Buenos Aires: Abeledo-Perrot, 1997.

GHERSI, Carlos Alberto (Coord.). Responsabilidad objetiva: el artículo 1113 y la Ley 24.999. Mendoza: Ediciones Jurídicas Cuyo, 1999. 
GHERSI, Carlos Alberto (Coord.). Responsabilidad: problemática moderna. Mendoza: Ediciones Jurídicas Cuyo, 1996.

GHERSI, Carlos Alberto. Teoria general de la reparación de daños. 2. ed., atual. e ampl. Buenos Aires: Astrea, 1999.

GIORGI, Giorgio. Teoria delle obligazioni nel diritto moderno italiano. 7. ed. Firenzi: Fratelli Cannelli, 1909. v. 5.

GOMES, Orlando. Direitos reais. 19. ed. atual. por Luiz Edson Fachin. Rio de Janeiro: Forense, 2007.

GOMES, Orlando. Introdução ao direito civil. 18. ed. Rio de Janeiro: Forense, 2002. v. 1.

GOMES, Orlando. Obrigações. 10. ed. Rio de Janeiro: Forense, 1995.

GOMES, Orlando. Obrigações. 16. ed. atual. por Edvaldo Brito. Rio de Janeiro: Forense, 2006.

GONÇALVES, Carlos Roberto. Direito civil brasileiro. São Paulo: Saraiva, 2006. v. V.

GONÇALVES, Carlos Roberto. Responsabilidade civil. 8· ed. São Paulo: Saraiva, 2003.

GONÇALVES, Luiz da Cunha. Tratado de direito civil. 2. ed. São Paulo: Max Limonad, 1956. v. XII, t. I.

GRINOVER, Ada Pelegrini. Teoria geral do processo. 22. ed. São Paulo: Malheiros, 2006. HIRONAKA, Giselda Maria Fernandes Novaes. Direito civil: estudos. Belo Horizonte: Del Rey, 2000.

HIRONAKA, Giselda Maria Fernandes Novaes. Responsabilidade pressuposta. Belo Horizonte: Del Rey, 2005.

HIRONAKA, Giselda Maria Fernandes Novaes. Os contornos jurídicos da responsabilidade afetiva na relação entre pais e filhos. In: HIRONAKA, Giselda Maria Fernandes Novaes (Coord.). A outra face do judiciário: decisões inovadoras e mudanças de paradigmas. Belo Horizonte: Del Rey, 2005. 
HIRONAKA, Giselda Maria Fernandes Novaes. Responsabilidade civil e contemporaneidade: retrato e moldura. Revista EPD, São Paulo, Escola Paulista de Direito, ano 1, n. 1, 2005.

HIRONAKA, Giselda Maria Fernandes Novaes. Responsabilidade pressuposta: evolução de fundamentos e de paradigma da responsabilidade civil na contemporaneidade. In: DELGADO, Mario Luiz; ALVES, Jones Figueiredo (Coord.). Questões controvertidas: responsabilidade civil. São Paulo: Método, 2006. v. 5.

INELLAS, Gabriel Cesar Zaccaria de. Da culpa aquiliana. São Paulo: Oliveira Mendes, 1998.

ITTURRASPE, Jorge Mosset. Responsabilidad civil. Buenos Aires: Hamurabi, 1997.

JORGE, Fernando de Sandy Lopes Pessoa. Ensaio sobre o pressuposto da responsabilidade civil. Lisboa: Centro de Estudos Fiscais, 1972.

JOSSERAND, Louis. Evolução da responsabilidade civil. Revista Forense, v. LXXXVI, jun. 1941.

LALOU, Henri. Traité pratique de responsabilité civile. 3. ed. Paris: Librairie Dalloz, 1943.

LARENZ, Karl. Derecho de obligaciones. Madrid: Editorial Revista de Derecho Privado, 1959. t. II.

LARENZ, Karl. Metodologia da ciência do direito. 3. ed. Lisboa: Fundação Calouste Gulbenkian, 1997.

LENZ, Luis Alberto Thompson Flores. A responsabilidade civil do Estado pela prática de ato lícito. Revista Justitia, v. 172, out./dez. 1995.

LENZ, Luis Alberto Thompson Flores. A responsabilidade civil frente à legítima defesa putativa. Revista dos Tribunais, São Paulo, n. 632, jun. 1998.

LIMA, Alvino. Culpa e risco. 2. ed. rev. e atual. pelo Prof. Ovídio Rocha Barros Sandoval. São Paulo: RT, 1998.

LISBOA, Roberto Senise. Manual de Direito Civil. 3. ed. São Paulo: RT, 2005. v. 4. 
LOBO, Paulo Luiz Netto. Teoria geral das obrigações. São Paulo, Saraiva, 2005.

LOPES, Miguel Maria de Serpa. Curso de direito civil. 4. ed. rev. e atual. por José Serpa Santa Maria. Rio de Janeiro: Freitas Bastos, 1995. v. V.

LOPES, Miguel Maria de Serpa. Curso de direito civil. 9. ed. Rio de Janeiro: Freitas Bastos, 2000. v. I.

LORENZETTI, Ricardo Luis. El sistema de la responsablidad civil ¿Una deuda de responsabilidad, un crédito de indemnizacíon o una relacíon jurídica? Ajuris, Porto Alegre, n. $63,1995$.

LORENZETTI, Ricardo Luis. Fundamentos do direito privado. São Paulo: RT, 1998.

LUMIA, Giuseppe. Elementos de teoria e ideologia do direito. São Paulo: Martins Fontes, 2003.

MALUF, Carlos Alberto Dabus. Do caso fortuito e da força maior excludentes de culpabilidade. Revista do Advogado da Associação dos Advogados de São Paulo, n. 44, 1994.

MALUF, Carlos Alberto Dabus. Do caso fortuito e da força maior excludentes de culpabilidade no Código Civil de 2002. In: DELGADO, Mario Luiz; ALVES, Jones Figueiredo (Coord.). Questões Controvertidas: responsabilidade civil. São Paulo: Método, 2006. v. 5.

MARIN, Rubens Leonardo. Dos sentidos da responsabilidade civil no Código Civil de 2002 e sua correlação aos tipos. In: TARTUCE, Flávio; CASTILHO, Ricardo (Org.) Direito civil: direito patrimonial e direito existencial. São Paulo: Método, 2006.

MARSHALL, Alfred. Princípios de economia: tratado introdutório. 3. ed. São Paulo: Nova Cultural, 1988.

MATTIA, Fábio Maria de. Direito de vizinhança e a utilização da propriedade imóvel. São Paulo: Bushatsky, 1976.

MATTIA, Fábio Maria de. Direito de vizinhança e a utilização da propriedade imóvel. São Paulo: Bushatsky, 1976. 
MAZEAUD, Henri; MAZEAUD, Leon. Traité théorique et pratique de la responsabilité civile delictuelle et contractuelle. 4. ed. Paris: Sirey,1949. t. I.

MEIRELLES, Hely Lopes. Direito de construir. 9. ed. São Paulo: Malheiros, 2005.

MELO, Marcos Bernardes de. Teoria do fato jurídico: plano da existência. 12. ed. São Paulo: Saraiva, 2003.

MONTEIRO, Adriano Malta. Schuld e Haftung: implicações filosóficas (obra ainda não publicada, cortesia do autor).

MONTEIRO, Washington de Barros. Curso de direito civil. Direito das obrigações: $2^{\mathrm{a}}$ parte. 35. ed. rev. e atual. por Carlos Alberto Dabus Maluf e Regina Beatriz Tavares da Silva. São Paulo: Saraiva, 2007. v. 5.

MONTEIRO, Washington de Barros. Curso de direito civil. Direito das coisas. 37. ed. Atualizado por Carlos Alberto Dabus Maluf. São Paulo: Saraiva, 2003. v. 3.

MONTENEGRO, Antonio Lindenberg C. Responsabilidade civil. 2. ed. Rio de Janeiro: Lumen Juris, 1996.

MORAES, Celina Bodim de. A constitucionalização do direito civil e seus efeitos sobre a responsabilidade civil. In: SARMENTO, Daniel; SOUZA NETO, Cláudio Pereira de. $A$ constitucionalização do direito. Rio de Janeiro: Lúmen Júri, 2007.

MORCILLO, Francisco Mochón. Introdução à economia. 2. ed. São Paulo: MakronBooks, 1994.

MOREIRA, José Carlos Barbosa. Responsabilidade do requerente de medida cautelar. Revista Ajuris, Porto Alegre, n. 27, mar. 1983.

MOTA PINTO, Carlos Alberto da. Teoria geral do direito civil. 3. ed. Coimbra: Editora Coimbra, 1994.

NALIN, Paulo Roberto Ribeiro. Responsabilidade civil: descumprimento do contrato e dano extrapatrimonial. Curitiba: Juruá, 1996.

NASCIMENTO, Tupinanbá Miguel Castro do. Direito real de servidão. Rio de Janeiro: AIDE. 1985. 
NIETZSCHE, Friedrich Wilhelm. Humano demasiado humano. São Paulo: Companhia das Letras, 2000.

NORONHA, Fernando. Direito das obrigações. São Paulo: Saraiva, 2003. v. 1.

PEREIRA, Caio Mário da Silva. Responsabilidade civil. 9. ed. Rio de Janeiro: Forense, 2001.

PEREIRA, Caio Mário da Silva. Instituições de direito civil. 19. ed. atual. por Carlos Edison do Rêgo Monteiro Filho. Rio de Janeiro: Forense, 2006. v. 4.

PERLINGIERI, Pietro. Perfis de direito civil. Tradução de Maria Cristina De Cicco. 3. ed. Rio de Janeiro: Renovar, 1997.

PINDYCK, Robert S.; RUBINFELD, Daniel L. Microeconomia. 4. ed. São Paulo: Makron-Books, 1999.

PODESTÁ, Fábio Henrique. Direito das obrigações: teoria geral e responsabilidade civil. 5. ed. São Paulo: Atlas, 2005.

PONTES DE MIRANDA, Francisco Cavalcanti. Tratado de direito privado. Campinas: Bookseller, 2000. t. II.

PONTES DE MIRANDA, Francisco Cavalcanti. Comentários ao Código de Processo Civil. Rio de Janeiro: Forense, 1976. t. XII.

PONTES DE MIRANDA, Francisco Cavalcanti. Tratado de direito privado. Campinas: Bookseller, 2001. t. XIII.

REALE, Miguel. Lições preliminares de direito. 26. ed. São Paulo: Saraiva, 2002.

RODRIGUES, Silvio. Direito civil. Direito das coisas. 24. ed. São Paulo: Saraiva, 1997. v. 5.

RUBINO, Domenico. La fattispecie e gli effetti giuridici preliminari. Milão: Giuffrè, 1939. RUGGIERO, Roberto de. Instituições de direito civil. 2. ed. Campinas: Bookseller, 2005.

SANTOS, J. M. Carvalho. Código Civil brasileiro interpretado: parte geral. 9. ed. Rio de Janeiro: Freitas Bastos, 1963. v. 3. 
SANTOS, Moacir Amaral. Primeiras linhas de direito processual civil. 7. ed. São Paulo, Saraiva, 1980.

SAVATIER, René. Traité de la responsabilité civile em droit français. Paris: Librairie Générale de Droit et de Jurisprudence, 1939. t. I.

SAVI, Sérgio. Responsabilidade civil por perda de uma chance. São Paulo: Atlas, 2006.

SILVA, De Plácido e. Vocabulário jurídico. 20. ed. Rio de Janeiro: Forense, 2002.

STARCK, Boris; ROLAND, Henri; BOYER, Laurent. Obligations: 1. Responsabilité délictuelle. 4. ed. Paris: Litec, 1991.

STIGLITZ, Gabriel A.; ECHEVESTI, Carlos A. El daño resarcible, In: ITTURRASPE, Jorge Mosset. Responsabilidad civil. Buenos Aires: Hamurabi, 1997.

STOCCO, Rui. Responsabilidade civil pela prática de atos lícitos. Revista dos Tribunais, v. 731 , set. 1996.

TELLES, Inocêncio Galvão. Direito das obrigações. 7. ed. Coimbra: Editora Coimbra, 1997.

TEPEDINO, Gustavo. Temas de direito civil. 2. ed. Rio de Janeiro: Renovar, 2001.

THEODORO JR., Humberto. Processo cautelar. 23. ed. São Paulo: Leud, 2006.

TRABUCCHI, Alberto. Instituzione de diritto civile. 5. ed. Pádua: Cedam, 1950.

TRUJILLO, Elcio. Responsabilidade do estado por ato lícito. Leme: LED, 1996.

TUCCI, Giuseppe. La risarcibilita'del danno da atto lecito nel diritto civile. Rivista di Diritto Civile, Padova, Cedam, ano XIII, 1967.

VARELA, João Matos Antunes. A responsabilidade no Direito, São Paulo, Folhetim IASP, 1982.

VARELA, João Matos Antunes. Das obrigações em geral. 10. ed. Coimbra: Almedina, 2003.

VARELA, João Matos Antunes. Das obrigações em geral. Coimbra: Almedina, 1970. 
VENOSA, Silvio de Salvo. Direito civil: direitos reais. 6. ed. São Paulo: Atlas, 2006.

VENOSA, Silvio de Salvo. Direito civil: responsabilidade civil. 6. ed. São Paulo: Atlas, 2006.

ZAVALA DE GONZÁLEZ, Matilde. Responsabilidad por el daño necesario. Buenos Aires: Editorial Astrea, 1985.

ZAVALA DE GONZÁLEZ, Matilde. Responsabilidad por riesgo. 2. ed. Buenos Aires: Hammurabi, 1997.

ZAVASCKI, Teori Albino. Antecipação de tutela e colisão de direitos fundamentais. Revista do Tribunal Regional Federal $1^{a}$ Região, v. 7, n. 3, jul./set. 1995.

ZITSCHER, Harriet Christiane. Introdução ao direito civil alemão e inglês. Belo Horizonte: Del Rey, 1999. 